\title{
CONTRIBUIÇÃO DO GLUTARALDEÍDO COMO COMPONENTE DE SISTEMAS ADESIVOS DENTINÁRIOS
}

\section{RENATO CILLI}

Tese apresentada à Faculdade de Odontologia de Bauru, da Universidade de São Paulo, como parte dos requisitos para obtenção do título de Doutor em Odontologia, Área de concentração: Dentística - opção Materiais Dentários. 



\section{CONTRIBUIÇÃO DO GLUTARALDEÍDO COMO COMPONENTE DE SISTEMAS ADESIVOS DENTINÁRIOS}

\section{RENATO CILLI}

Tese apresentada à Faculdade de Odontologia de Bauru, da Universidade de São Paulo, como parte dos requisitos para obtenção do título de Doutor em Odontologia, Área de concentração: Dentística - opção Materiais Dentários.

Orientador: Prof. Dr. Paulo Amarante de Araújo 


\begin{tabular}{|c|c|}
\hline \multirow[t]{2}{*}{ C489c } & $\begin{array}{l}\text { Cilli, Renato } \\
\text { Contribuição do glutaraldeído como componente de } \\
\text { sistemas adesivos dentinários / Renato Cilli. - Bauru, } \\
2007 . \\
\quad 99 \text { p. : il. : } 30 \mathrm{~cm}\end{array}$ \\
\hline & $\begin{array}{l}\text { Tese (Doutorado) - Faculdade de Odontologia de } \\
\text { Bauru. Universidade de São Paulo. }\end{array}$ \\
\hline
\end{tabular}

Autorizo, exclusivamente para fins acadêmicos e científicos, a reprodução total ou parcial desta tese, por processos fotocopiadores e outros meios eletrônicos.

Assinatura:

Comitê de Ética da FOB

No. do Protocolo: 31/2004; 51/2005

Data: 10/05/2004; 05/07/2005 


\section{RENATO CILLI}

22 de setembro de 1973

São Caetano do Sul - SP

Filiação

1993-1996

$1998-2000$

$2001-2003$

2003-2007
Nascimento

Nilson Cilli e

Felícia Stelmack Cilli

Curso de Graduação em Odontologia, na Faculdade de Odontologia de Piracicaba, da Universidade Estadual de Campinas UNICAMP

Estágio no Departamento de Materiais Odontológicos e Prótese da Faculdade de Odontologia de São José dos Campos, da Universidade Estadual Paulista "Júlio de Mesquita Filho" - UNESP

Curso de Pós-Graduação em Dentística opção Materiais Dentários, nível Mestrado, na Faculdade de Odontologia de Bauru, da Universidade de São Paulo - USP

Curso de Pós-Graduação em Dentística opção Materiais Dentários, nível Doutorado, na Faculdade de Odontologia de Bauru, da Universidade de São Paulo - USP 


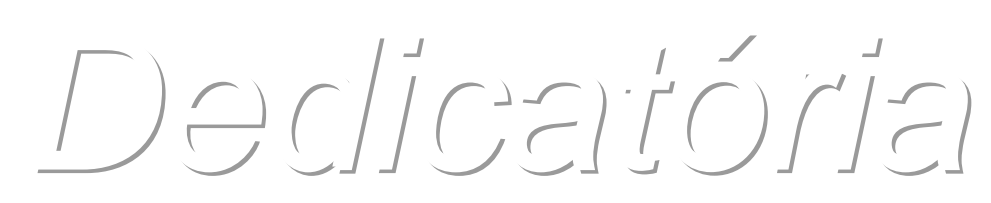

Aos meus pais, Nilson e Felícia 


\section{Agradecimentos}

Agradecimentos especiais:

À Deus e Nossa Senhora,

Por me darem saúde para conseguir chegar até este estágio.

Ao Professor Dr. Paulo Amarante de Araújo, Pela amizade, enriquecimento cultural e científico, demonstrações de carinho, honestidade, comprometimento e pela honrosa orientação deste trabalho.

A Anuradha,

Por todo o amor, que inclui amizade, carinho, consideração, compreensão e comprometimento 


\section{Agradecimentos não menos importantes:}

Ao Prof. Dr. Paulo Afonso Silveira Francisconi, Pelos ensinamentos, amizade, demonstrações de caráter, confiança e pelo bom humor.

Ao Prof. César Antunes de Freitas, Pelos ensinamentos, amizade e conselhos.

Ao Prof. Dr. Elliot W. Kitajima, Pelos ensinamentos, dedicação e confiança.

Ao Alcides Urias da Costa, Sandra P. Azuaga e Lourisvalda de J. Celestino, Pela amizade, grande ajuda e confiança.

Ao Nelson, Rita e Ângela da Dentística, Pela amizade e ajuda. Ao Ovídio e Thelma da Bioquímica, Pela ajuda e amizade.

À Daniela e Tânia da Histologia, Pela ajuda e disponibilidade. Aos amigos e colegas de curso,

Heitor, Daniela Rios, Leonardo, Anderson, Kiyoshi, Diego, Angélica, Giovana, Ian, Terezinha, Eduardo, Leandro, Breno, Sérgio Sábio, Rosana, Fernando, Márcia, Fabiane,

Cristiane, Dafna, Juliana e Cala Gianini, Pela amizade e convivência.

Aos demais professores, colegas de Bauru e funcionários da FOB, Não aqui listados por problemas de espaço e esquecimento, mas que de alguma forma foram importantes, ou para a realização deste trabalho ou na minha passagem por Bauru. 


\section{SUMÁRIO}

página

$\begin{array}{lr}\text { LISTA DE FIGURAS } & \text { xi } \\ \text { LISTA DE TABELAS } & \text { xiii } \\ \text { LISTA DE ABREVIATURAS E SIMBOLOS } & \text { xv } \\ \text { RESUMO } & \text { xix } \\ \text { 1. INTRODUÇÃO } & 1 \\ \text { 2. REVISÃO DA LITERATURA } & 5 \\ \text { 3. PROPOSIÇÃO } & 35 \\ \text { 4. MATERIAL E MÉTODO } & 39 \\ \text { 5. RESULTADOS } & 49 \\ \text { 6. DISCUSSÃO } & 57 \\ \text { 7. CONCLUSÃO } & 67 \\ \text { 8. ANEXOS } & 71 \\ \text { 9. REFERÊNCIAS } & 85 \\ \text { ABSTRACT } & 97\end{array}$




\section{LISTA DE FIGURAS}

página

Fig. 2.1

Diferentes ângulos de contato entre substrato e líquidos.

(adaptado de Ruyter, 1992)

Figs. 2.2. A-G

Estágios principais durante 0 desenvolvimento do tecido

dentinário (adaptado de van Rensburg, 1995)

Fig. 2.2.H Representação esquemática das fases de desenvolvimento do colágeno, começando da seqüência de aminoácidos em escala nanométrica, até a escala das fibras de colágeno de cerca de $10 \mu \mathrm{m}$ de diâmetro. Adaptado de Buehler, $2006^{16}$.

Ésteres metacrílicos de ácido fosfórico usados em alguns

Fig. 2.3 sistemas autocondicionantes. $\mathrm{n}=$ número de grupos metileno nos compostos. Adaptado de Tay, Pashley (2001) ${ }^{102}$.

Fig. 2.4.A Mecanismo de reação entre aldeído, proteína e HEMA, conforme declarado por Munksgaard (1986). (Adaptado de Ruyter, 1992)

Fig. 2.4.B Fórmula estrutural do glutaraldeído $\left(\mathrm{C}_{5} \mathrm{H}_{8} \mathrm{O}_{2}\right)$. Sinônimos: 1,3diformilpropano, glutaral, glutardialdeído, dialdeído glutárico, 1,5pentanedial, 1,5-pentanedione, ácido glutaraldeído potencial. CAS No. $111-30-8$

Fig. 4.3 Esquematização representativa dos procedimentos adesivos adotados para cada grupo

Fig. 5.1 Gráfico tipo box-plot onde visualiza-se os valores médios de resistência de união, distribuição amostral e desvio padrão em função de cada grupo estudado

Fig. 5.2.1 Imagem representativa de um stub contendo os palitos a terem sua área adesiva examinada.

Fig. 5.2.2 Imagem representativa de espécime apresentando fratura do tipo MR.

Fig. 5.2.3.a Imagem representativa de espécime apresentando fratura do tipo MD.

Fig. 5.2.3.b Maior aumento da imagem anterior. Nota-se a fratura na camada híbrida e em dentina. 
Fig. 5.2.4 Imagem representativa de espécime apresentando fratura do tipo A. Nota-se fratura na camada híbrida, em topo e corpo.

Fig. 5.2.5 Outra imagem representativa de espécime apresentando fratura do tipo A. Nota-se fratura completa em topo da camada híbrida.

Fig. 5.2.6.a Imagem representativa de espécime apresentando fratura do tipo A. Nota-se fratura na camada híbrida, em topo e corpo.

Fig. 5.2.6.b Maior aumento da imagem anterior. Nota-se também fratura em base de camada híbrida.

Fig. 5.2.7.a Imagem representativa de espécime apresentando fratura do tipo A. Nota-se fratura na camada híbrida, em topo e corpo.

Fig. 5.2.7.b Maior aumento da imagem anterior, para confirmação.

Fig. 5.2.7.c Maior aumento da imagem anterior.

Fig. 5.2.8 Imagem representativa de espécime apresentando presença de esmalte na área adesiva.

Fig. 5.2.9 Grupo GS: a) Fotomicrografia representativa da camada híbrida formada; b) Maior aumento. r: resina composta; h: camada híbrida; $\mathrm{d}$ : dentina; t: prolongamentos resinosos

Fig. 5.2.10 Grupo GU: a) Fotomicrografia representativa da camada híbrida formada; b) Maior aumento. r: resina composta; h: camada híbrida; $\mathrm{d}$ : dentina; t: prolongamentos resinosos.

Fig. 5.2.11 Grupo U: a) Fotomicrografia representativa da camada híbrida formada; b) Maior aumento. r: resina composta; h: camada híbrida; $\mathrm{d}$ : dentina; t: prolongamentos resinosos

Fig. 5.2.12 Grupo S: a) Fotomicrografia representativa da camada híbrida formada; b) Maior aumento. $r$ : resina composta; h: camada híbrida; $\mathrm{d}$ : dentina; t: prolongamentos resinosos 


\section{LISTA DE TABELAS}

página

Tabela 2.4 Diversas formulações comerciais do sistema Gluma, segundo $\begin{array}{ll}\text { informações dos fabricantes } & 29\end{array}$

Tabela 4.1.a Materiais selecionados 41

Tabela 4.1.b Identificação do lote e prazo de validade dos principais materiais $\quad 42$

Tabela 5.1.a Médias de resistência de união, desvio padrão e comparativo de Tukey 51

Tabela 5.1.b Teste de Tukey $(\alpha=0,05)$

Tabela 5.2 Classificação das fraturas observadas em MEV 53

Tabelas 8.1 Espessura, valores de resistência a tração em kgf e em MPa e tipo de fratura observada em MEV dos palitos obtidos de cada dente de acordo com seu respectivo grupo. Valores em negrito na base da tabela representam a média. Valores tachados indicam espécime eliminado após confirmação, através de MEV, de presença de esmalte na área adesiva. GU, GS, S e U: grupos estudados; d: dente. A: 100\% adesiva; MR: mista, com parciais fraturas adesiva e coesiva em resina; MD: mista, com parciais fraturas adesiva e coesiva em dentina; MRD: mista, com parciais fraturas adesiva e coesiva em resina e em dentina; CR: $100 \%$ coesiva em resina; CD: 100\% coesiva em dentina; E: presença de esmalte. 


\section{LISTA DE ABREVIATURAS E SÍMBOLOS}

\begin{tabular}{|c|c|}
\hline$\%$ & por cento \\
\hline$\delta_{\mathrm{h}}$ & unidade de parâmetro de solubilidade para pontes de \\
\hline & hidrogênio de Hansen \\
\hline$\mu \mathrm{m}$ & unidade de comprimento: micrometro \\
\hline${ }^{\circ} \mathrm{C}$ & unidade de temperatura: graus Celsius \\
\hline$\alpha$ & nível de significância estatística \\
\hline$\varepsilon$ & letra grega épsilon \\
\hline Bis-GMA & Bisfenol-A diglicidil metacrilato \\
\hline 4-META & 4-metacriloiloxietil-trimelitato anidrido \\
\hline BMP-1 & $\begin{array}{l}\text { bone morphogenetic protein-1 (proteína mofogenética } \\
\text { do osso-1 ou proteína morfogenética do corpo-1) }\end{array}$ \\
\hline BPDM & bisfenil-dimetacrilato \\
\hline CAS & $\begin{array}{l}\text { Chemical Abstracts Service (número de registro } \\
\text { químico) }\end{array}$ \\
\hline $\mathrm{cm}$ & unidade de comprimento: centímetro \\
\hline CS-GAG & $\begin{array}{l}\text { condroitin-sulphate glycosaminoglycan (condroitina- } \\
\text { sulfato glicosaminoglicana) }\end{array}$ \\
\hline Di-HEMA & 2-hidroxietilmetacrilato hidrogênio fosfato \\
\hline dinas/cm & unidade de tensão superficial: dinas por centímetro \\
\hline $\mathrm{dp}$ & desvio-padrão \\
\hline EDTA & ácido etilenodiaminotetracético \\
\hline $\mathrm{ergs} / \mathrm{cm}^{2}$ & $\begin{array}{l}\text { unidade de energia de superfície: ergs por centímetro } \\
\text { quadrado }\end{array}$ \\
\hline et al. & e colaboradores \\
\hline Fig. & figura \\
\hline Figs. & figuras \\
\hline $\mathrm{g} / \mathrm{mL}$ & unidade de volume: mililitro \\
\hline GAG & glicosaminoglicana \\
\hline GPDM & glicerofosfato dimetacrilato ácido \\
\hline GS & grupo de experimental GS \\
\hline GU & grupo de experimental GU \\
\hline $\mathrm{h}$ & unidade de tempo: hora (s) \\
\hline
\end{tabular}




\begin{tabular}{|c|c|}
\hline $\mathrm{HCl}$ & ácido clorídrico \\
\hline HEMA & 2-hidroxietilmetacrilato \\
\hline Ind. & indeterminado \\
\hline ISO & International Organization for Standardization \\
\hline kgf & unidade de força: quilograma-força \\
\hline KS-GAG & $\begin{array}{l}\text { keratin-sulphate glycosaminoglycan (queratina-sulfato } \\
\text { glicosaminoglicana) }\end{array}$ \\
\hline $\mathrm{kV}$ & unidade de voltagem: quilovolts \\
\hline $\mathrm{lbs} / \mathrm{pol}^{2}$ & unidade de pressão: libras por polegada ao quadrado \\
\hline $\mathrm{m}$ & unidade de comprimento: metro \\
\hline MET & microscopia eletrônica de transmissão \\
\hline MEV & microscopia eletrônica de varredura \\
\hline $\mathrm{mm}$ & unidade de comprimento: milímetro \\
\hline $\mathrm{mm}^{2}$ & unidade de área: milímetros ao quadrado \\
\hline $\mathrm{mm} / \mathrm{min}$ & unidade de velocidade: milímetro por minuto \\
\hline $\mathrm{mmHg}$ & unidade de pressão: milímetros de mercúrio \\
\hline $\mathrm{MPa}$ & unidade de pressão: mega-pascal \\
\hline $\mathrm{mW} / \mathrm{cm}^{2}$ & $\begin{array}{l}\text { unidade de potência luminosa: miliwatt por centímetro } \\
\text { quadrado }\end{array}$ \\
\hline N.I. & não informado \\
\hline $\mathrm{NaOCl}$ & hipoclorito de sódio \\
\hline $\mathrm{NaOH}$ & hidróxido de sódio \\
\hline NCP & non-collagenous protein (proteína não-colagênica) \\
\hline $\mathrm{nm}$ & unidade de comprimento: nanometro \\
\hline NPG-GMA & $\mathrm{N}$-fenil-glicil metacrilato de glicidila \\
\hline$p$ & nível de confiabilidade estatística \\
\hline PG & proteoglicana \\
\hline $\mathrm{pH}$ & potencial hidrogêniônico \\
\hline \multirow[t]{2}{*}{ PMDM } & produto da reação da adição de dianidrito piromelítico \\
\hline & ao HEMA \\
\hline rpm & unidade de velocidade:rotações por minuto \\
\hline s & unidade de tempo: segundo (s) \\
\hline S & grupo experimental S \\
\hline St. & Saint \\
\hline
\end{tabular}


TEGDMA

U

UDMA

$X$

tetraetilenoglicoldimetacrilato

grupo experimental $U$

uretano dimetacrilato

número de vezes (aumento) 
Resumo 


\section{RESUMO}

Neste trabalho foram testadas as seguintes hipóteses nulas: 1) Não há diferença entre os valores de resistência de união entre resina restauradora e dentina quando uma solução aquosa de glutaraldeído é aplicada como primer dentinário antes do emprego do agente adesivo; 2) Não há diferença entre os valores de resistência de união, quando a aplicação do mesmo sistema adesivo se dá em condições de dentina úmida ou seca. Dentes humanos foram selecionados, e tiveram sua porção oclusal desgastada, expondo a parte média da dentina coronária para adesão. Quatro grupos foram formados, variando-se a aplicação ou não do primer de glutaraldeído e a condição de umidade dentinária: úmida ou seca. Após aplicação e fotopolimerização do sistema adesivo experimental, foram confeccionados blocos resina composta de $4 \mathrm{~mm}$ de altura sobre a superfície oclusal e os dentes foram preparados para o teste de microtração para a avaliação da resistência de união. Os resultados obtidos foram submetidos à análise de variância a um critério e teste de Tukey $(\alpha=0,05)$. A aplicação do primer de glutaraldeído aumentou significativamente os resultados de resistência de união. Não houve diferença estatística entre o mesmo sistema experimental se aplicado em dentina seca ou úmida. $A$ hipótese 1 não se confirma e aceita-se a hipótese 2.

\section{PALAVRAS-CHAVE}

Glutaraldeído. Resistência à tração. Dentina. 
Introdução 



\section{INTRODUÇÃO}

Embora na odontologia o ideal seria o desenvolvimento de materiais ou tecidos biológicos que atendessem as necessidades de se restaurar ou reconstituir os dentes humanos acometidos pelos diversos tipos de lesões como cáries, erosões e fraturas, tal estágio ainda não foi alcançado. Na busca de um material artificial biocompatível, as resinas compostas foram desenvolvidas ${ }^{14}$ e continuam sendo constantemente aprimoradas. Paralelamente a esse desenvolvimento, encontram-se os adesivos dentinários, que são os agentes de união utilizados para que resina composta e tecidos dentais se combinem de melhor forma.

Brevemente dizendo, em esmalte dental, tal combinação é melhor alcançada pela interdifusão dos monômeros resinosos do adesivo nas irregularidades superficiais conseguidas através de um ataque ácido prévio ${ }^{17}$, que desmineraliza, aumentando assim a energia de superfície deste tecido ${ }^{40}$. Em dentina, a dinâmica torna-se diferente, devido à constituição e aspecto morfológico singulares deste tecido. Deste ponto, divergem-se tarefas árduas e envolventes que conduzem pesquisadores à encontrarem as respostas para os diversos problemas que a adesão à dentina apresenta.

A dentina, um tecido vivo complexo ${ }^{55}$, é composta basicamente de minerais de hidroxiapatita, colágeno e água ${ }^{56,89}$. A técnica atualmente mais aceita para a promoção de adesão resinosa à esse substrato envolve princípios micromecânicos baseados na formação da camada híbrida, pioneiramente caracterizada por Nakabayashi, Kojima e Matsuhara em $1982^{62}$.

A camada híbrida é formada pela interdifusão dos monômeros resinosos, presentes no adesivo dentinário, nos espaços entre as fibrilas de colágeno ocupados previamente por minerais e que foram desmineralizados por um ataque ácido. De um outro lado, foram também propostas e estudadas, formas de união química entre resinas e componentes dentinários. Neste grupo, destacam-se os trabalhos de Asmussen, Munksgaard e colaboradores ${ }^{6,59,60}$, que desenvolviam o adesivo chamado Gluma, composto basicamente de glutaraldeído e HEMA.

No compasso de seu desenvolvimento, o Gluma veio apresentando diversas formulações, porém, seu mecanismo químico de ação chegou a ser desacreditado pois julgava-se que o mesmo ou não existisse ou contribuísse muito pouco para a adesão, em específico, para a força de união à dentina ${ }^{69,92}$. Entretanto, com o 
passar dos anos e com os conhecimentos advindos das diversas pesquisas realizadas neste campo dos adesivos dentinários, desponta-se um novo anseio de contribuir cientificamente através de um estudo mais minucioso do processo de união baseado no sistema Gluma, através da investigação do seu componente principal, o glutaraldeído. Teoricamente, tal componente é o elo de ligação química entre o colágeno e os monômeros resinosos do adesivo ${ }^{6,59,60}$ e o presente trabalho visou obter evidências que apontem sua importância ou não de sua utilização como componente de um sistema de união dentinário. 


\section{Revisão de}

\section{literatura}

Neste tópico, foram abordados sucintamente todos os assuntos que julgamos pertinentes em relação à adesão em substrato dentinário e a utilização do glutaraldeído, que podem dar sustentação ao trabalho de investigação proposto.

Tais assuntos foram explorados de modo a direcionar o raciocínio em volta das questões que acompanham o tema. 



\section{REVISÃO DE LITERATURA}

\subsection{Adesão}

O fenômeno adesão pode ser definido como o estado em que duas superfícies estão intimamente unidas por forças físicas, químicas ou ambas, com ou sem a intermediação de um promotor de união, denominado comumente de adesivo $^{27,38}$.

A adesão química é baseada em forças de valência primária, onde ocorre uma combinação atômica entre as moléculas dos materiais envolvidos, como no caso de ligações iônicas, covalentes e metálicas. Esta categoria de união é considerada forte ${ }^{25,27}$.

A adesão física baseia-se em forças de valência secundária. Essas forças de atração resultam da interação de dipolos moleculares e/ou atômicos. São elas: as forças de van der Walls e as ligações de hidrogênio (pontes de hidrogênio) ${ }^{25,27}$.

Diferentemente das ligações primárias, que são intramoleculares, as ligações secundárias são intermoleculares, sendo por este fato, mais fracas ${ }^{1}$.

A adesão física entre dois materiais dissimilares também pode ser conseguida utilizando-se princípios físico-mecânicos. Comumente, esta variante é denominada adesão mecânica. A adesão mecânica é referida à penetração de um material em outro em nível microscópico, perfazendo um embricamento ${ }^{27}$.

Para ocorrer adesão, as superfícies aderentes dos materiais devem atrair-se uma à outra em sua interface de união. A energia livre de superfície, que pode ser entendida como a energia disponível para ligações apresentada pelos átomos da superfície de um material, tem substancial importância. Como os átomos residentes no interior do material estão completamente interligados (condição que não ocorre na superfície) eles acabam exercendo uma atração entre os átomos superficiais, ocasionando uma tensão chamada de tensão superficial. A tensão superficial é expressa em dinas/cm, enquanto que a energia de superfície é expressa em ergs/ $\mathrm{cm}^{2}$.

A adesão entre dois sólidos é muito difícil de ocorrer. Por mais lisa que as superfícies aparentam ser, microscopicamente ou em nível molecular ou mesmo atômico, elas apresentam-se rugosas, dotadas de grandes irregularidades ${ }^{1}$. Isso impede aquele íntimo contato entre as moléculas ou átomos de ambas superfícies 
aderentes, cuja distância não deveria exceder $1 \mathrm{~nm}^{27}$. Como esta situação é quase impossível de ocorrer entre dois sólidos dissimilares em toda extensão de suas superfícies aderentes, um promotor de união, o adesivo, deve ser utilizado. Este, geralmente em forma líquida, penetrará nas irregularidades superficiais, proporcionando um embricamento e, consequentemente, criará uma interface de união. Ele pode ser definido então, como um material que quando aplicado em superfícies de duas substâncias possui a capacidade de uni-las, oferecendo resistência à separação ${ }^{47}$.

O líquido adesivo deverá possuir, como requisito mínimo, uma tensão superficial igual ou ligeiramente menor que o valor de energia de superfície do material aderente. Desta maneira, ele se espalharia uniformemente e espontaneamente ${ }^{29,83}$. Entretanto, o mesmo acaba ocorrendo quando a energia de superfície do substrato aderente é bem maior que a tensão superficial do adesivo, devido à grande atração e disponibilidade para ligações que os átomos (e moléculas) desta superfície apresentariam.

O grau desse espalhamento pode ser chamado de umedecimento, uma vez que é o resultado da capacidade de uma gota de um líquido em molhar a superfície de um sólido, ou o resultado de sua capacidade de molhamento ${ }^{27}$.

Esta capacidade de molhamento é determinada pelo ângulo de contato entre líquido e sólido. Quanto menor o ângulo de contato (próximo de zero), maior o umedecimento e, quanto maior, menor o umedecimento (Fig. 2.1) 1,27,29,83.

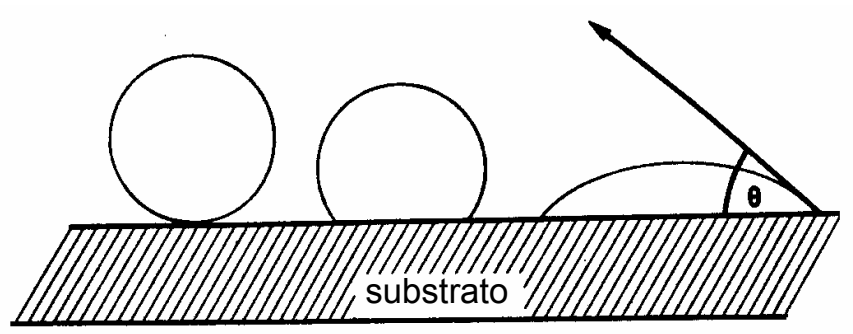

Fig. 2.1 - Diferentes ângulos de contato entre substrato e líquidos. (adaptado de Ruyter, 1992 ${ }^{83}$ )

Resumindo, sendo a tensão superficial do líquido adesivo menor ou ligeiramente menor que a energia de superfície do substrato aderente, isso determinaria um ângulo de contato próximo de zero entre os materiais, perfazendo um alto grau de umedecimento da superfície. 
Todos esses conceitos podem ser observados e são bastante empregados na Odontologia para se obter adesão em tecidos biológicos como o esmalte e dentina. Usualmente, para adesão com materiais de origem polimérica, são utilizados os chamados sistemas adesivos.

O esmalte recém preparado apresenta uma tensão superficial de cerca de 28 dinas $/ \mathrm{cm}^{40}$, sendo esta condição incompatível com adesivos modernos que apresentam por volta de 41 dinas $/ \mathrm{cm}^{29}$. O ataque da superfície do esmalte com ácidos causa uma desmineralização seletiva, aumentando a superfície de contato, a rugosidade e, consequentemente, a energia livre de superfície. Valores em torno de 72 dinas/cm são conseguidos com o condicionamento com ácido fosfórico a $40 \%{ }^{40}$.

A dentina recém-preparada apresenta uma tensão superficial de cerca de 44 dinas/cm. Porém, após seu condicionamento com alguns tipos de ácidos, este valor pode cair para cerca de 28 dinas $/ \mathrm{cm}^{29}$. O referido decréscimo pode ser explicado pela criação de uma superfície irregular, porquanto porosa, com aumento de sua permeabilidade (exposição dos túbulos dentinários), e em conseqüência disso, dominada pelo afloramento de líquido (sobretudo água) proveniente de seu interior (fluido tissular). Ela possui características de uma membrana semipermeável, pois respeita os princípios da osmose. Quando soluções hipertônicas (como os ácidos) são aplicadas em sua superfície, ela tende a compensar o gradiente de concentração com o fluido tissular ${ }^{72,74,78}$.

Este problema fora solucionado com o tratamento prévio da superfície condicionada com soluções que continham monômeros resinosos em conjunto com solventes, os primers. Os solventes apresentam função de deslocar a quantidade de água presente na dentina desmineralizada para infiltração simultânea dos monômeros. Como os primers apresentam uma tensão superficial de cerca de 41 dinas $/ \mathrm{cm}^{29}$, eles permitem um bom molhamento do adesivo nesta modificada superfície. Os fabricantes adequam a tensão superficial do adesivo para que seja ligeiramente menor que a do primer.

\subsection{Dentina}

A dentina é talvez um dos tecidos mais complexos do corpo humano. É o segundo tecido mais mineralizado, apresentando, segundo Marshall Junior et al. ${ }^{56}$, 
volume constituído de cerca de $50 \%$ de mineral rico em carbonatos, possuindo apatita deficiente em cálcio; $30 \%$ de matéria orgânica -essencialmente colágeno tipo I; e $20 \%$ de fluido, semelhante ao plasma, porém, sem característica definida ${ }^{56,89}$. Em peso, segundo Mjör; Fejerskov $(1986)^{57}$ apud van Meerbeek $(1993)^{108}$, apresenta cerca de $75 \%$ de constituintes inorgânicos, cerca de $18 \%$ de substância orgânica e $12 \%$ de água. Estes dados podem possuir variações na literatura ${ }^{13,28,73,111}$.

A porção inorgânica da dentina consiste quase que exclusivamente de apatita, principalmente a hidroxiapatita, embora uma quantidade de fosfato de cálcio amorfo esteja também presente ${ }^{111}$. Estes cristais de apatita são relativamente bem menores quando comparados com aqueles encontrados em esmalte -cerca de 300 vezes $^{13,89}$.

Na matriz orgânica, encontramos com predominância o colágeno, perfazendo $93 \%$ de sua massa total, sendo o restante constituído de $0,9 \%$ de ácido cítrico, $0,2 \%$ de proteínas insolúveis, $0,2 \%$ de glicosaminoclicanas e também a mesma quantia de lipídios ${ }^{89,111}$.

Sua estrutura é formada por células odontoblásticas e substância extracelular, que reside em torno dos prolongamentos destas células, ou também, entre os túbulos dentinários. Alguns autores incluem os odontoblastos, como são chamadas estas células, como parte integrante do órgão pulpar e, portanto, denominam este conjunto dentina-polpa de complexo dentino-pulpar ${ }^{82}$.

A substância extracelular é, nada mais, do que composta de fibrilas colágenas entremeadas em substância mineral. Esta matriz de fibrilas é disposta perpendicularmente à junção amelo-dentinária quando próxima desta. Esta camada de fibrilas caracteriza e identifica a chamada dentina do manto. Nesta região, tais fibrilas se apresentam com maior calibre. Deste ponto em direção à polpa, elas se tornam mais finas, entrelaçadas e se dispõem perpendicularmente à direção dos túbulos. Esta é denominada dentina circumpulpar.

Todas estas características podem ser mais bem elucidadas com análise da origem do tecido dentinário, a dentinogênese, sendo ela também necessária para o entendimento do processo dinâmico de mineralização deste tecido, que se prolonga por toda a vida do órgão.

Os estágios principais do desenvolvimento do tecido dentinário são ilustrados na seqüência de figuras (Figs. 2.2 A-G, adaptadas de van Rensburg, $1995^{111}$ ): 
Durante as fases embrionárias, é originado a partir do ectomesênquima, um conjunto de células conhecido como papila dental. Este conjunto de células inicialmente dispõe-se irregularmente, estando situado logo abaixo do epitélio do órgão formador do esmalte. As células são muito parecidas umas com as outras (Fig. 2.2.A). Antes da formação dos odontoblastos, uma fina camada periférica destas células é diferenciada no que se acreditam ser os pré-odontoblastos. Ela é produzida pela indução do mesênquima papilar pela camada de células do ainda precoce epitélio do esmalte. Fibras produzidas na periferia dessa papila sofrem mudanças marcantes neste período (Fig. 2.2.B).

Fibras perdidas

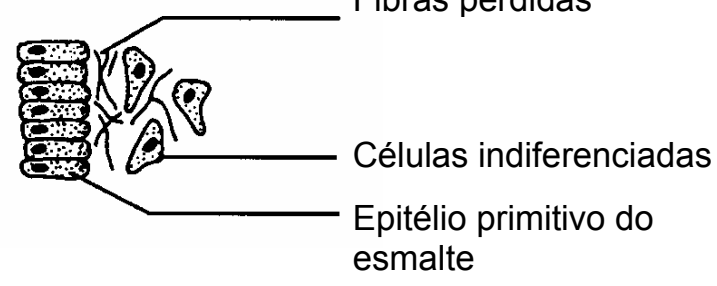

Fig. 2.2.A - células mesenquimais indiferenciadas da papila dental

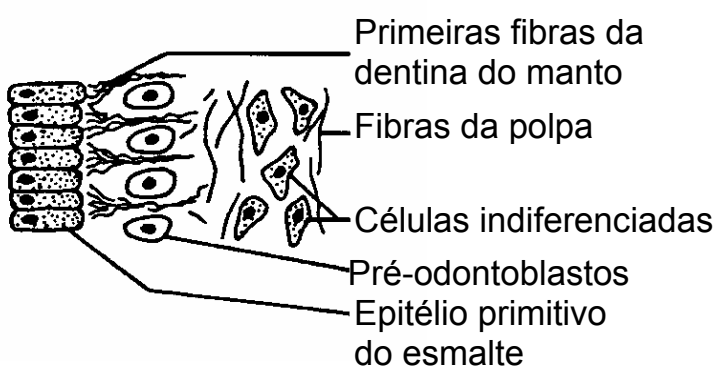

Fig. 2.2.B - Pré-odontoblastos

O primeiro estágio da formação da dentina é a deposição continuada de fibras colágenas numa substância amorfa rica em glicosaminoglicanas (Fig. 2.2.C e 2.2.D). Elas se arranjam numa rede com orientação perpendicular e justaposta ao imaturo epitélio do esmalte. São denominadas fibras de von Korff, e formarão a matriz orgânica da dentina do manto.

A partir deste ponto, a papila dental passará a ser chamada de polpa dental, sendo separada do epitélio formador do esmalte pelas fibras de von Korff. Os préodontoblastos se diferenciam então em odontoblastos, perdendo a capacidade de realizar a divisão celular ou mitose. As fibrilas começam a se depositar em direção paralela à superfície pulpar, tendo neste estágio, o início da formação da dentina circumpulpar (Fig. 2.2.D). 


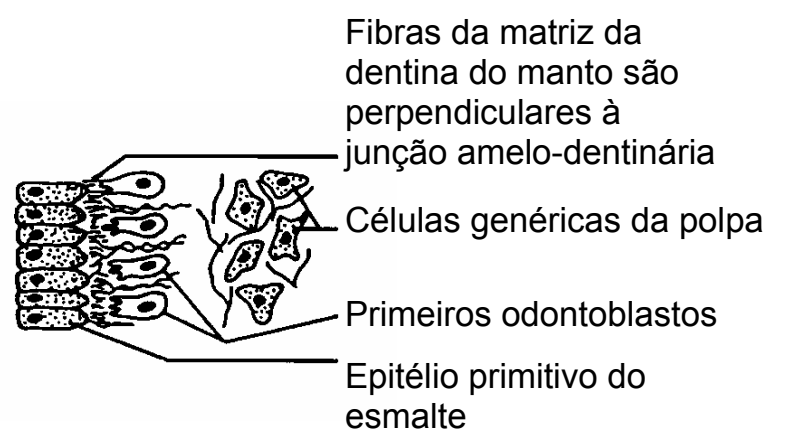

Fig. 2.2.C - Odontoblastos

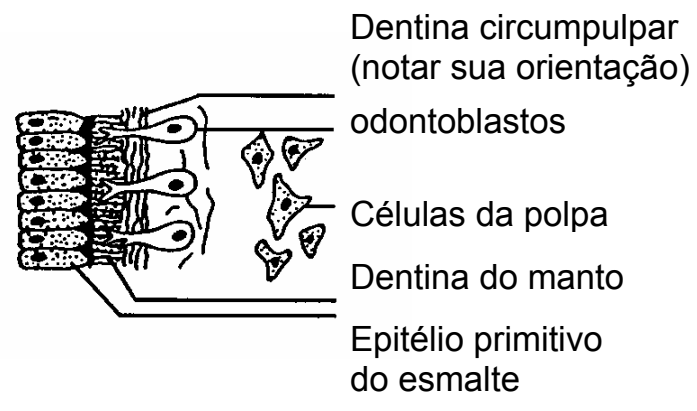

Fig. 2.2D - Formação da matriz

Conforme ocorre a deposição das fibras, o corpo dos odontoblastos acompanha o espessamento da dentina, sempre em direção à polpa, deixando um fino prolongamento citoplasmático por todo o curso (Fig. 2.2.E). Acredita-se que tanto os pré-odontoblastos como os odontoblastos sejam responsáveis pela produção de fibrilas colágenas neste estágio.

Quando a mineralização finalmente se inicia, túbulos dentinários são formados em torno dos prolongamentos odontoblásticos, se estendendo então, do corpo da célula até a junção amelo-dentinária (Fig. 2.2.F). Eles se assemelharão a cones, apresentando a base voltada para o corpo dos odontoblastos ou superfície pulpar. No entanto, são ondulados, devido aos movimentos espiralados dos odontoblastos durante a formação dentinária. Ainda, em sua extensão, o túbulo dentinário apresenta uma série de canais laterais, originados pela mineralização de pequenos prolongamentos laterais que se encontram no percurso do maior. Estes canais estão mais presentes na dentina radicular do que em dentina coronária, sendo também mais finos comparativamente.

A camada de dentina adjacente à polpa permanece não-mineralizada através de toda a vida pulpar, e é conhecida como pré-dentina, tendo de 10 a $20 \mu \mathrm{m}$ de espessura (Fig. 2.2.F). 


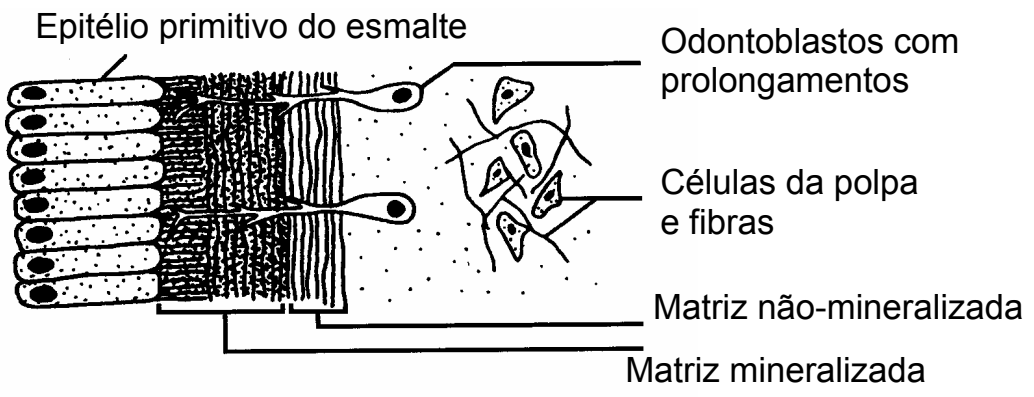

Fig. 2.2.E - Formação da matriz e

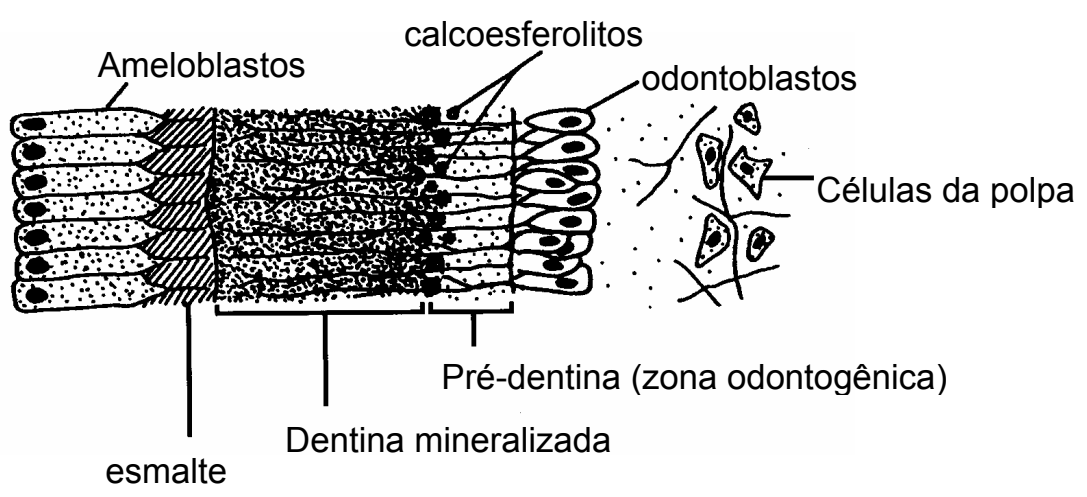

Fig. 2.2.F - Mineralização

A mineralização é histologicamente vista como a formação de esferas, de calcoesferolitos ou material inorgânico que se coalesce e aumenta em tamanho para formar a dentina completamente mineralizada (Fig. 2.2.F). Os calcoesferolitos são secretados pelos odontoblastos e formam a hidroxiapatita, que é dispersa entre a trama de colágeno. Estes calcoesferolitos são transportados pelos prolongamentos citoplasmáticos através do fluido tissular, e precipitados da porção final para a base.

As fibrilas de colágeno são recobertas com os mucopolissacarídeos ácidos presentes na matriz e possuem a tendência de atrair minerais ${ }^{86}$.

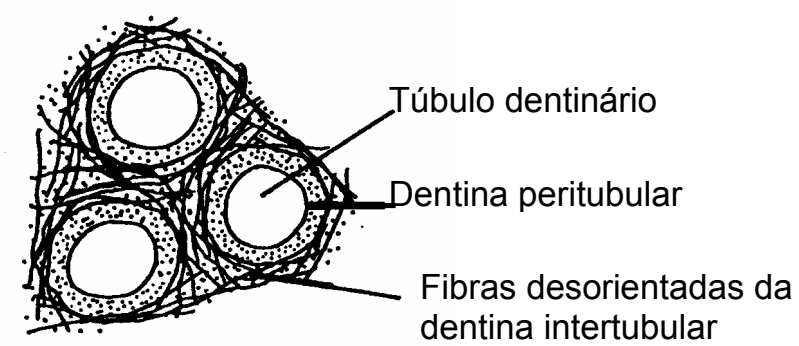

Fig. 2.2.G - Dentina peritubular e intertubular (secção transversal) 
O mineral é depositado na direção da coroa para a raiz dental, em incrementos cônicos, resultando na formação de linhas incrementais (linhas de von Ebner). Os calcoesferolitos se fusionam formando uma massa homogênea. Porém, numa certa região, essa fusão pode ser incompleta, resultando no aparecimento de espaços interglobulares. Essa região é chamada de dentina interglobular e se localiza logo abaixo da junção amelo-dentinária. A razão para o fenômeno ainda não é conhecida.

A dentina mineralizada situada entre os túbulos dentinários é denominada dentina intertubular e a dentina formadora dos túbulos é denominada dentina peritubular, ou intratubular. A dentina peritubular é cerca de $9 \%$ mais mineralizada que a dentina intertubular ${ }^{13}$ (Fig. 2.2.G).

Próximo à polpa, os túbulos são mais calibrosos e em maior número, cerca de 65 mil túbulos $/ \mathrm{mm}^{2}$, enquanto que na periferia encontra-se aproximadamente 15 mil túbulos $/ \mathrm{mm}^{2}$ devido ao estreitamento de sua luz. No meio caminho entre as duas regiões, encontra-se cerca de 35 mil túbulos $/ \mathrm{mm}^{2}$. O diâmetro médio dos túbulos varia de 1 a $5 \mu \mathrm{m}$, sendo que a média é de $1,5 \mu \mathrm{m}^{111}$.

Um dos constituintes mais importantes da dentina é o colágeno e merece uma atenção à parte. $O$ termo colágeno não diz respeito à uma molécula em especial mas sim a toda uma família específica de proteínas, sendo conhecidos mais de 20 tipos em tecidos animais. Estas são macromoléculas quimicamente e geneticamente distintas que, com freqüência podem se agregar formando fibras, que servem como matriz de sustentação para certos tecidos do corpo, como os conectivos ou de conexão. Segundo Sano et al. ${ }^{85}$, cerca de $30 \%$ da resistência a tração da dentina é conferida à presença de colágeno. Em termos biomecânicos, pode-se imaginar que os túbulos de alta concentração mineral, ou seja a dentina peritubular, possui um papel importante na resistência à compressão da dentina, enquanto que a porção menos mineralizada, a dentina intertubular, forma a matriz responsável pela alta consistência e resistência à propagação de fraturas ${ }^{112}$. 
As moléculas de colágeno tipo I dentinárias são secretadas por células do tipo odontoblasto e/ou fibroblasto em sua forma solúvel, o procolágeno. A estrutura da molécula de procolágeno pode ser dividida em três regiões: 1- uma curta extremidade amina, não triplo-hélice (N-telopeptídeo); 2- Uma longa cadeia central ininterrupta em triplo-hélice e; 3- Uma outra curta extremidade carboxílica, não triplo-hélice (C-telopeptídeo) $)^{114}$. O procolágeno é transformado em colágeno por atividade enzimática no meio extacelular, perdendo as extremidades não tripohélices e tornando a macromolécula insolúvel ${ }^{33}$.

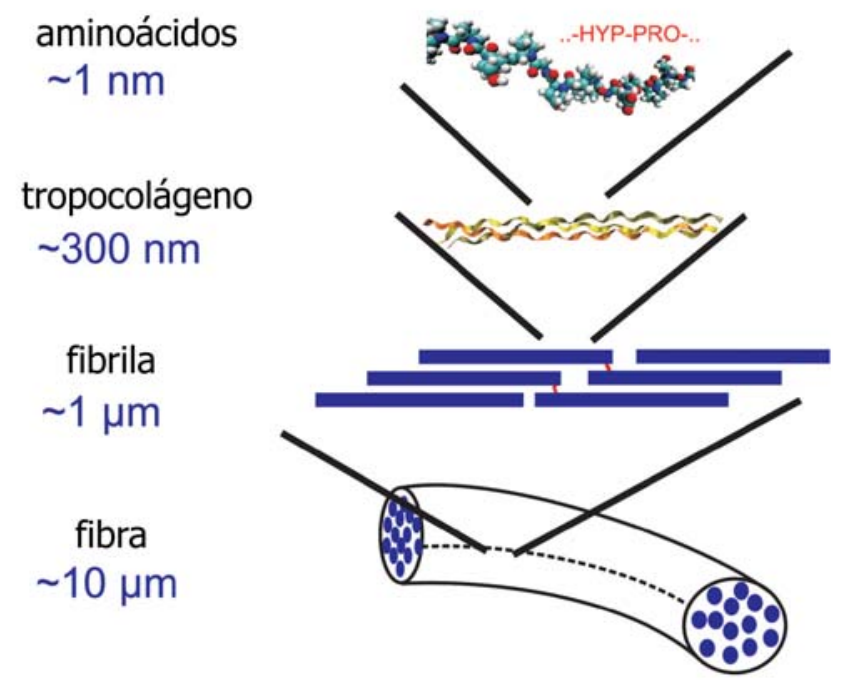

Figura $2.2 \mathrm{H}$ - Representação esquemática das fases de desenvolvimento do colágeno, começando da seqüência de aminoácidos em escala nanométrica, até a escala das fibras de colágeno de cerca de $10 \mu \mathrm{m}$ de diâmetro. Adaptado de Buehler, $2006^{16}$.

Muito do conhecimento atual sobre colágeno advém de pesquisas sobre o colágeno tipo I, que é a classe mais abundante no corpo humano ${ }^{41}$. Na dentina, por exemplo, o tipo I representa cerca de $90 \%$ do total, sendo que traços de colágeno tipo III, IV e V podem ser encontrados ${ }^{33}$.

As moléculas de colágeno tipo I são estruturas cilíndricas alongadas altamente assimétricas, tendo em comprimento cerca de $300 \mathrm{~nm}$ e diâmetro de $1,5 \mathrm{~nm}$, sendo a proporção entre eixos de cerca de 200:1 ${ }^{112}$. Cada molécula de colágeno do tipo I apresenta um desenho helicoidal, composto de três cadeias individuais de polipeptídeos (cadeias $\alpha$ ) de dois tipos, $\alpha 1(\mathrm{I})$ e $\alpha 2(\mathrm{I})$, com a resultante fórmula molecular: $[\alpha 1(\mathrm{I})]_{2}[\alpha 2(\mathrm{I})]$, formando uma tripo-hélice, também chamada de tropocolágeno $^{16,112}$. Dependendo do tipo de colágeno, as três cadeias $\alpha$ podem ser 
idênticas (homotrimer), ou diferentes (heterotrimer), sendo que cada cadeia $\alpha$ de tropocolágeno tem cerca de 1000 aminoácidos ${ }^{35}$. A molécula de colágeno tipo I é uma heterotrimer ${ }^{114}$.

A estrutura helicoidal, triplo-hélice, é estabilizada pela alta quantidade de aminoácidos, ou seja, essencialmente prolina e hidroxiprolina. A presença de hidroxiprolina é essencial para a formação de pontes de hidrogênio entre as cadeias, que promovem a estabilização da estrutura no formato triplo-hélice. As pontes de hidrogênio, ou também chamadas de forças de hidratação entre as moléculas de colágeno, permite também que tais macromoléculas da tripla-hélice não se aproximem muito umas das outras ${ }^{51}$, quando ocorreria o colapso delas, e têm fundamental importância nas propriedades mecânicas da estrutura, com reflexos importantes nas propriedades da dentina.

A interação entre moléculas de tropocolágeno, de forma espontânea, formam fibrilas, estabilizadas devido a ligações intermoleculares covalentes cruzadas ${ }^{114}$. Para a formação das fibrilas, cada molécula de colágeno (tropocolágeno) se sobrepõe à molécula vizinha em aproximadamente $1 / 4$ de seu comprimento. Tais sobreposições são identificadas ultraestruturalmente como bandas periódicas ou cross-bandings, com período de repetição de 67-69 nm. Nessas áreas, há espaços, ou poros, entre as moléculas, permitindo ligações covalentes entre elas. Nestes espaços, permite-se a deposição de hidroxiapatita durante o processo de mineralização da matriz dentinária ${ }^{104}$, visto anteriormente. Teoricamente, esses poros são abertos durante a desmineralização da dentina por ácidos, dando espaço para que os monômeros resinosos penetrem e se relacionem intimamente com as fibrilas.

Da mesma forma, fibrilas podem se agrupar formando fibras (Figura 2.2H). Entretanto, na dentina, apenas fibrilas são encontradas.

Os $10 \%$ restantes da matriz orgânica são compostos por proteínas ditas nãocolagênicas (NCP), incluindo principalmente as fosfoproteínas, como as sialoproteínas e fosfoforinas e as proteoglicanas (PG), como as glicosaminoglicanas: biglicanas, decorinas, lumicanas, fibromodulinas. As biglicanas e decorinas constituem-se em sua maioria de pequenas glicosaminoglicanas ricas em leucina e carregadas de condroitina (CS-GAG) e as lumicanas e fibromodulinas constituem as queratina-sulfato glicosaminoglicanas (KS-GAG) $^{33,79}$. As CS-GAG são a maioria das GAGs presentes na dentina, seguida por pequenas quantidades de dermatano-sulfato, KS-GAG e ácido hialurônico ${ }^{33}$. 
Outras NCPs de maior interesse são encontradas no plasma dentinário (proteínas do plasma), sendo a albumina a maior representante deste grupo ${ }^{33}$.

A real função das proteínas não-colagênicas ainda é incerta, porém acreditase que elas participem do processo de fibrilogênese, e que sua ligação com as fibrilas de colágeno impede seu completo preenchimento por minerais ("calcificação") durante a mineralização da dentina. Especificamente, a habilidade das proteoglicanas em se ligar ao colágeno é importante para a formação e organização das fibras e fibrilas ${ }^{105}$. As cadeias de GAG possuem atração por cátions como o cálcio, pois são altamente carregadas negativamente e, logo, possuem característica hidrofílica ${ }^{79,105}$. Estudos recentes apontam sua importância no processo de adesão. A remoção de cadeias de CS-GAG implica em relativa perda da capacidade da malha de colágeno dentinária em se re-expandir hidricamente após desidratação, trazendo como conseqüência a diminuição de suas propriedades mecânicas. Entretanto, a remoção das cadeias de KS-GAG parece não trazer prejuízos ao processo adesivo ${ }^{79}$.

\subsection{Adesão à dentina}

Infelizmente, e comparativamente com o que ocorre em termos de adesão com o esmalte, os adesivos dentinários não alcançaram ainda o mesmo estágio de sucesso. Para tal sorte, eles deveriam exibir valores de resistência ao deslocamento adesivo próximos aos que se obtém com substratos de esmalte dental, além de possuírem uniões duradouras, o que parece ser atualmente um dos grandes desafios.

As primeiras tentativas de se obter união de resinas com a dentina ocorreram com o desenvolvimento do composto dimetacrilato glicerofosfórico ácido (GPDM) por Oscar Hagger, em 1951 ${ }^{61,89}$. Por apresentar um grupamento fosfato hidrofílico, esta resina permitia ligação com o cálcio dentinário por quelação ${ }^{83}$. Este material foi denominado comercialmente como Sevitron Cavity Seal, sendo pela primeira vez avaliado por Kramer; Mc Lean, em $1952^{50}$.

Apesar de estes serem os primeiros indícios da utilização de ácidos para obter-se a união resina-dente, o grande marco da história da Odontologia Adesiva ocorreu com o sucesso de Michael G. Buonocore, em $1955^{17}$, que foi quem consagrou a técnica de condicionamento prévio do esmalte por ácidos para união 
de resinas acrílicas. Hoje se sabe que com esta técnica podemos mais que dobrar a tensão de superficial do esmalte (de cerca de 28 para até cerca de 72 dinas $/ \mathrm{cm})^{40,108}$, para assim, permitir uma maior facilidade de umedecimento da superfície pelo adesivo.

Buonocore et al., em $1956^{18}$, realizaram algumas das primeiras tentativas de condicionamento da dentina por ácidos ( $\mathrm{HCl}$ a $7 \%$ por um minuto), no entanto, sem o esperado sucesso. Na ocasião, os agentes de união da época eram hidrofóbicos, e por esta razão funcionavam bem em esmalte e mal em dentina. A quantidade de água no esmalte é muito inferior àquela presente na dentina, além de haver a possibilidade de trabalharmos com uma superfície extremamente seca.

O que acontece, na realidade, é que não podemos considerar esmalte e dentina como substratos iguais ou parecidos, pois não são. Pelo menos quando tratamos de adesão.

As diferenças entre esmalte e dentina começam pela sua constituição. 0 tecido esmalte é quase que integralmente constituído de minerais, cerca de $97 \%$ em peso. A dentina, como já foi descrito anteriormente, apresenta grande conteúdo mineral, no entanto oferece um obstáculo, que é a sua parte protéica e fluidos ${ }^{77}$. Estes dois fatores compõem a chave da questão sobre adesão em dentina.

Ocorria durante os trabalhos que Buonocore liderava, uma redução da energia da superfície da dentina (ao contrário do esmalte) ao se realizar o ataque ácido. Dessa maneira, não se alcançava um bom umedecimento pelos adesivos hidrofóbicos. Outro agravante era a hipertonicidade que o ácido provocava na superfície, fazendo com que os fluidos tissulares fossem atraídos osmoticamente para esta região, acabando por provocar também a dificuldade do adesivo hidrofóbico em penetrar-se no tecido.

A presença de fibras colágenas é responsável pela baixa energia de superfície da dentina desmineralizada por ácidos -cerca de 28 dinas $/ \mathrm{cm}^{29}$. Como a aplicação direta de adesivos hidrofóbicos necessita de uma superfície livre de água (e obviamente seca), as fibras colágenas expostas e desprovidas de suporte mineral se apresentarão colapsadas neste caso, devido à atração proporcionada pela energia livre de superfície da dentina mineralizada subjacente ${ }^{73}$. A dentina desmineralizada e seca atinge valores de até $65 \%$ de contração em volume ${ }^{22}$, limitando em muito os espaços entre as fibrilas para a difusão do adesivo.

Os trabalhos de Buonocore ficaram então esquecidos por longo tempo, pois adiante se iniciou uma série de discussões sobre os potenciais efeitos agressivos 
sobre a polpa pelo ácido, quando aplicado em esmalte e dentina, que perduraram por muitos anos (quase 20) e se intensificaram principalmente durante a década de 1970. Somente em 1975, após a realização do simpósio internacional em St. Paul, Estados Unidos, o ataque ácido em esmalte foi genericamente aceito pela comunidade odontológica mundial ${ }^{89}$. Entretanto, persistia o ceticismo em relação ao condicionamento em dentina.

Devido ao pequeno sucesso de Buonocore e ao receio dos pesquisadores, os trabalhos que se seguiram, durante a década de 1980, buscaram a união química com a dentina, mais precisamente com a camada de detritos (smear layer) produzida após o preparo cavitário ou instrumentação. O pioneirismo foi de Rafael Lee Bowen ${ }^{15}$, com o desenvolvimento de uma resina, a NPG-GMA, que possuía propriedades de ligação com os componentes minerais da dentina por quelação. Esse agente de ligação estava presente (à época) nos agentes de união Cosmic Bond (De Trey Co.) e Cervident (SS White). Depois, seguiu-se uma nova geração de monômeros adesivos bifuncionais (hidrofílicos/hidrofóbicos) baseados em fosfatos e fosfanatos, que também objetivavam a ligação com o cálcio dentinário ${ }^{83,89}$. Alguns representantes dessa época foram o Scothbond (3M), Clearfil New Bond (Kuraray), Adaptic Dentin Bonding Agent (Johnson \& Johnson) e o Prisma Universal Bond (Caulk-Dentsply).

Ao realizar a adesão por ligações químicas primárias (iônicas ou metálicas) com a porção mineral dentinária, estes adesivos objetivavam preservar a camada de detritos para oferecer proteção pulpar, devido à obliteração dos túbulos dentinários. Sendo assim, eles não conseguiam penetrar muito bem na dentina, restringindo-se mais à camada de detritos. Estes sistemas produziam valores muito baixos de resistência adesiva, ou seja, por volta de $5 \mathrm{MPa}$, sendo este valor apontado à resistência coesiva da própria camada de detritos ${ }^{37,69,94}$.

Tentativas de união química por ligações estruturais com os constituintes dentais também foram descritas. Asmussen e Munksgaard acreditavam promover uma adesão química (combinação estrutural) entre monômeros resinosos e o colágeno dentinário, através de sistemas adesivos que removiam a camada de detritos e que continham glutaraldeído e $\operatorname{HEMA}^{6,59,60}$. Devido à presença deste último, os adesivos se tornaram mais hidrofílicos, com maior capacidade de molhamento e de penetração no substrato dentinário ${ }^{69}$.

Entretanto, trabalhos posteriores reportaram que a adesão nesta técnica era essencialmente formada por união micromecânica ${ }^{69,92}$. A eficiência de união com o 
colágeno promovida pela presença do aldeído na formulação do adesivo se existia, era considerada empírica e insignificante no resultado final.

O adesivos representantes dessa época eram o Gluma (Bayer-Miles), que contém glutaraldeído e HEMA, e o Scotchbond 2 (3M), contendo HEMA. Este último, trazia em seu sistema um primer (Scotchprep), apresentando uma solução de ácido maléico (2,5\%), HEMA (55\%) e traços de ácido metacrílico ${ }^{83,69}$, sendo lembrado como o primeiro primer autocondicionante ${ }^{69,83,110}$.

Paralelamente à estes estudos, Takao Fusayama, no Japão, ao final da década de 1970 e início da de 80, insistia em seus trabalhos, no condicionamento ácido total, ou seja, de esmalte e dentina simultaneamente ${ }^{32}$. A técnica original consistia no condicionamento total da cavidade com gel de ácido fosfórico a 40\%. Provia uma satisfatória adesão em esmalte, porém ocorria um sobrecondicionamento da dentina, e o colapso das fibras colágenas, pois era recomendado a completa secagem da dentina com jato de ar. Mesmo assim, acreditava-se que com os adesivos específicos desta técnica (por exemplo, o Clearfil Liner Bond $F$, Kuraray) podia-se ter uma união química com a dentina ${ }^{31,61}$, obtendo bons valores de adesão.

Em 1982, Nobuo Nakabayashi et al. ${ }^{62}$, encontraram através de ensaios de tração, uma resistência de adesão à dentina por volta de $18 \mathrm{MPa}$ e a existência de uma zona de interdifusão de resina entre a camada de adesivo e a camada de dentina mineralizada subjacente, quando cortes foram observados ao MEV. Essa camada hibridizada que, nada mais é que a inter-relação entre os monômeros resinosos infiltrados e a trama de colágeno desmineralizada, fora denominada de camada híbrida. A descoberta e o posterior entendimento deste mecanismo de adesão veio por derrubar a opinião daqueles que pensavam que a adesão à dentina dependia apenas da infiltração de resina nos túbulos, com a formação de prolongamentos ou tags.

Nakabayashi, Kojima e Masuhara ${ }^{62}$ utilizaram um sistema de união que apresentava um agente condicionante composto de uma solução de $10 \%$ de ácido cítrico e $3 \%$ de cloreto férrico. Este condicionador era aplicado em esmalte e dentina simultaneamente e provia a remoção total da camada de detritos dentinários. Acreditava-se inicialmente que o cloreto férrico atuava como promotor de polimerização. Anos depois, descobriu-se que o cloreto férrico, que interagia quimicamente com a dentina, também impedia parcialmente que a trama de 
colágeno se colapsasse. Especula-se que o mesmo atua na malha de colágeno promovendo ligações entre peptídeos, estabilizando- $a^{61}$.

A partir dessa época, sedimentou-se a idéia do condicionamento total para a remoção completa da camada de detritos, para então, promover a união com a dentina através da infiltração dos monômeros resinosos por entre as fibras colágenas expostas pelo ataque ácido. Este conceito é atualmente considerado como o principal mecanismo de união à dentina ${ }^{61}$.

Os sistemas adesivos desenvolvidos a partir desta época, no início da década de 1990, possuíam também características bifuncionais, ou seja, possuíam componentes hidrofílicos e hidrofóbicos na mesma molécula de monômero e buscavam a adesão micromecânica proporcionada pela formação da camada híbrida. Resinas hidrofílicas incluem comumente monômeros hidrofílicos como os baseados em fosfatos, ácido poliacrílico, HEMA, TEGDMA, NPG-GMA, PMDM, 4META, BPDM ${ }^{89,93}$.

Sua utilização apresentava peculiarmente três passos durante o procedimento: o condicionamento ácido, a aplicação de um primer dentinário e a aplicação da resina fluida. No primer é que se encontrava a molécula bifuncional, além de solventes como acetona, água e álcool etílico que tinham como função deslocar (caçar) e promover a rápida evaporação da água presente entre as fibras de colágeno ${ }^{89,93,110}$, permitindo que o monômero preenchesse esses espaços. Os primers podem possuir um ou uma combinação destes solventes. A permeação do monômero bifuncional na dentina inerentemente úmida é facilitada pela presença de radicais hidrofílicos em sua molécula.

Mais do que isso, e como já dito anteriormente, os primers promovem uma tensão superficial adequada para a interação com o adesivo hidrofóbico (resina fluida), ou seja, eles transformam uma condição de superfície hidrófila para hidrófoba ${ }^{110}$, por apresentarem radicais hidrofóbicos em sua constituição. O adesivo hidrofóbico teria a função de estabilizar a camada híbrida, promovendo sua conexão com a resina composta restauradora ${ }^{52,110}$.

Adiante e recentemente, seguiu-se uma tentativa de simplificação desta técnica, devido à sua sensibilidade e desconforto (número de passos) que proporcionava aos clínicos. Foram introduzidos no Mercado, sistemas adesivos de dois passos (ataque ácido + adesivo), que incluíam a resina e o primer em um só frasco. Quase que em seqüência, foram lançados também os sistemas de passo 
único ou autocondicionantes (primers autocondicionantes e adesivos autocondicionantes).

Os sistemas autocondicionantes incluem a presença do ácido entre seus componentes. Ao mesmo tempo em que há a desmineralização dentinária, ocorre a permeação dos monômeros bifuncionais. Esta categoria de adesivos apresenta uma delgada camada híbrida, porém sem grande comprometimento de sua efetividade em relação aos seus predecessores de dois passos, pois até o momento, não há evidências de relação entre espessura de camada híbrida e resistência de união69,78,106. A menor espessura teoricamente é devida à diminuição gradual da acidez do primer protagonizada pela capacidade tampão dentinária.

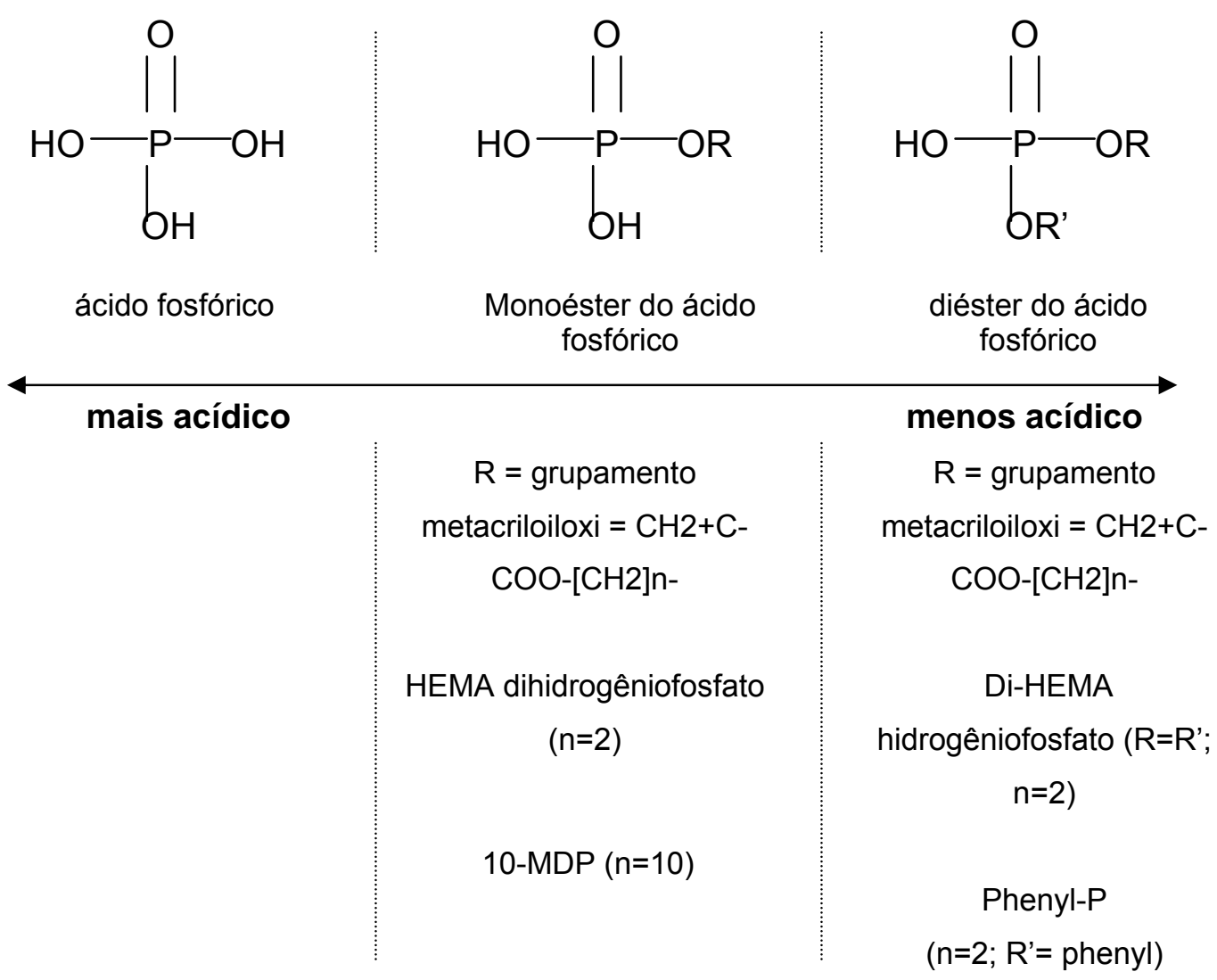

Fig. 2.3 - Ésteres metacrílicos de ácido fosfórico usados em alguns sistemas autocondicionantes. $\mathrm{n}=$ número de grupos metileno nos compostos. Adaptado de Tay, Pashley $(2001)^{102}$. 
A diferença entre primers autocondicionantes e adesivos autocondicionantes está na agressividade ${ }^{103}$ (Fig. 2.3) e na porcentagem de monômeros acídicos em suas composições, que está situada entre 5 a $6 \%$ para os primers e cerca de $20 \%$ ou mais para os adesivos ${ }^{73}$.

\subsubsection{Umidade dentinária e outros fatores relevantes à adesão}

Mesmo com os avanços conquistados ao longo de quarenta anos, a adesão à dentina ainda não atingiu pleno sucesso, o que seria alcançado quando os materiais adesivos pudessem selar completamente a interface dente-restauração, com resistência adesiva que suportasse os ciclos mastigatórios e os ciclos térmicos inerentes ao ambiente bucal. Adicionalmente, é bom lembrar que estes materiais devem ser preferivelmente inertes, ou biocompatíveis, e que sua ação adesiva perdurasse por longo tempo sem degradação.

O estágio em que encontramos atualmente é de grandes conquistas em termos de resistência de união e de intimidade dos sistemas com a ultra-estrutura dentinária. No entanto, a técnica se apresenta extremamente sensível, exigindo dos clínicos, habilidade, conhecimento altamente específico e atualizações constantes. Não é à toa que o sucesso do procedimento obtido em laboratório dependerá, na prática clínica, substancialmente do operador -o cirurgião-dentista.

Como já descrito anteriormente, a baixa resposta dentinária em relação aos primeiros adesivos hidrofóbicos conduziu os pesquisadores da área à formulação de sistemas bifuncionais, com certa afinidade pela água, um dos constituintes dentinários mais relevantes.

A umidade da dentina é outro fator preocupante. Os adesivos modernos, principalmente aqueles que utilizam um pré-tratamento com ácido fosfórico como passo separado, têm sua técnica baseada na adesão úmida, primeiramente apresentada por John Kanca III, em 1992 ${ }^{42,43}$. A presença de umidade superficial (umidade extrínseca) previamente à aplicação dos adesivos é essencial para a formação da camada híbrida e ganho de resistência de união ${ }^{80}$.

Solventes como acetona e álcool etílico presentes nos primers, aumentam a pressão de vapor da água presente na dentina, deslocando-a ou promovendo sua evaporação da porção mais superficial ${ }^{42,43}$. Com isso, permitem a infiltração concomitante dos monômeros bifuncionais. Então, a secagem excessiva 
previamente à aplicação do primer diminui a efetividade destes, pois não haveria umidade superficial suficiente para a ação dos solventes e penetração dos monômeros ${ }^{42,43}$.

Adesivos formulados com solventes com água ou água e álcool etílico parecem ser menos sensíveis a uma certa secagem da superfície (mas não em excesso) do que aqueles que somente apresentam acetona ou só álcool etílico, pois a água reumedeceria a porção parcialmente desidratada ${ }^{42,43}$. Entretanto, a presença de uma certa umidade (de aspecto brilhante) é recomendada para evitar o colapso das fibras colágenas da camada de dentina desmineralizada.

Por outro lado, foi demonstrado que o colapso da camada de dentina desmineralizada pela secagem exagerada é reversível. O volume colapsado é capaz de expandir perto de $100 \%$ do volume original com um novo umedecimento por água ${ }^{22}$. No entanto, a injúria ao tecido pulpar talvez seja definitiva ${ }^{25}$.

O padrão de umidade segundo recomenda Kanca III, ou seja, de uma condição em que a umidade seja percebida apenas por tornar a superfície levemente brilhante, deve ser respeitada. O excesso de umidade pode gerar 0 fenômeno overwet, descrito por Franklin Tay et al. ${ }^{101}$ como sendo o aparecimento de vesículas e de glóbulos de resina do primer no interior da camada híbrida. As vesículas são formadas pelo aprisionamento (recobrimento) de gotículas de água pela resina presente no primer. Os glóbulos de resina seriam decorrentes da diluição dos monômeros no excesso de água. Esses glóbulos e vesículas podem atuar como áreas concentradoras de estresses e prejudicar a resistência de união. Deficiências na formação de prolongamentos resinosos ou tags são observadas nas regiões correspondentes ao fenômeno ${ }^{93}$. Pereira et al., em $1999^{80}$, demonstraram através de análise em MEV que mesmo em situações de ausência de pressão hidrostática intrapulpar positiva (como em testes laboratoriais), era possível ocorrer o fenômeno de overwet em regiões dentinárias próximas de cornos pulpares, principalmente quando se utilizam sistemas adesivos que dependem da técnica úmida e do ataque ácido prévio, agravando-se quando estes apresentam somente acetona como solvente.

O excesso de água presente na dentina pode ainda combinar-se com o primer, alterando sua formulação e podendo causar a separação de monômeros em fases diferentes ${ }^{4,69,91,101}$. Como conseqüência, pode comprometer o recobrimento das fibrilas de colágeno por resina, deixando áreas expostas e mais susceptíveis a degradação ${ }^{21,90}$. 
A sensibilidade da técnica é aumentada também pela profundidade do preparo dental em relação à polpa. Como já elucidado anteriormente, o número e o calibre dos túbulos dentinários cresce em relação à proximidade da polpa. Há de se esperar então, uma maior dificuldade de realização dos procedimentos adesivos, uma vez que teremos uma maior quantidade de água e menor quantidade de dentina intertubular. $\mathrm{E}$ devido à menor área de dentina intertubular, eleva-se a importância da formação de prolongamentos de resina ou tags em relação à resistência total adesiva, enquanto que na dentina superficial a maior responsabilidade é devida à formação da camada híbrida ${ }^{69,71,73}$. Valores mais baixos de resistência de união são relacionados diretamente ao grau de profundidade dentinária ${ }^{42,43}$.

Os sistemas adesivos modernos também possuem dificuldade de preencher por completo toda a camada de dentina superficial que foi desmineralizada pela ação do ácido, resultando no aparecimento da denominada camada de dentina não-infiltrada. A primeira observação desta ocorrência foi feita por Sano et al. $(1995)^{84}$ notando a infiltração da solução contrastante de nitrato de prata nesta camada porosa não-preenchida pelo sistema adesivo. À este tipo de infiltração eles chamaram de nanoinfiltração, termo que advém da espessura desta camada (de 20 a $100 \mathrm{~nm}$ ). A presença de nanoinfiltração pode levar a camada híbrida à degradação mais rapidamente, por hidrólise ${ }^{52,63,76,100,109}$.

Paul et al. ${ }^{76}$, em 1999, observaram em MEV esta camada porosa de dentina não-infiltrada pelo sistema adesivo Single Bond (3M). Neste estudo, o aumento do tempo de condicionamento da dentina (30 e 60 segundos, contra o convencional 15 segundos) determinou uma maior extensão de desmineralização superficial, com conseqüente maior penetração de nitrato de prata pela zona de dentina nãopreenchida ou não-infiltrada pelo adesivo, o que só confirma a incapacidade dos monômeros presentes no sistema adesivo de preencherem grandes espessuras criadas pela desmineralização.

Os adesivos autocondicionantes teoricamente contornam melhor este problema, pois ao mesmo tempo em que ocorre a desmineralização pelo grupamento ácido do monômero acídico, ocorre também sua penetração através da camada de detritos e dentina inter e intratubular ${ }^{69}$. Entretanto, é esperado que a possível diferença de tonicidade, entre a superfície (que está ácida e seca) e o interior da dentina, pode fazer aflorar água para esta superfície (umidade intrínseca dentinária), como manutenção do equilíbrio osmótico. Isto poderia ocorrer mesmo 
antes e durante a foto-polimerização do adesivo, como também depois. Recentemente foi demonstrado por Tay et al. ${ }^{103}$ (2002) que a camada adesiva formada por esta categoria de agente de união atua como uma membrana semipermeável mesmo depois de fotopolimerizada, permitindo a difusão de líquido do interior da dentina para a superfície do adesivo. O fenômeno ocorre pela formação de um gradiente de concentração entre os túbulos dentinários, que apresentam baixa quantidade de soluto, e a superfície do adesivo (mais precisamente a camada inibida pelo oxigênio), que apresenta alta quantidade devido a presença de proteínas dissolvidas, monômeros hidrofílicos nãopolimerizados e íons inorgânicos resultantes do processo de desmineralização. A presença de água na superfície pode afetar tanto a capacidade de adesão do adesivo à dentina como sua interação com os materiais resinosos hidrofóbicos. Este tipo de especulação ainda merece ser melhor investigada.

Ambas as umidades dentinárias extrínsecas e intrínsecas devem ser consideradas para a promoção de uma adesão bem sucedida ${ }^{80}$.

Alguns primers autocondicionantes, como o Prime \& Bond 2.1 e NT, apresentam a recomendação da técnica do ataque ácido total pelos seus fabricantes. Nesta técnica, e em teoria, os primers autocondicionantes acabariam desmineralizando uma quantidade adicional de dentina superficial, o que resultaria em maiores chances de incapacidade dos monômeros em preencher toda a camada de colágeno exposta.

Outro importante fator a ser considerado durante o processo adesivo é a contração que os monômeros resinosos sofrem durante polimerização. Esta pode causar concentrações de estresses em certas regiões da superfície dentinária, que podem resultar em defeitos que levariam ao deslocamento total da restauração. Esses estresses podem ser maiores se forem utilizados materiais restauradores de alto módulo de elasticidade ${ }^{89}$. As tensões geradas pela resina restauradora durante a polimerização podem chegar ao valor de $7 \mathrm{MPa}$. Entretanto, este dado varia de acordo com a configuração cavitária, o Fator $C^{30,89,93}$.

\subsection{Utilização do glutaraldeído e o Sistema Gluma}

Num tempo onde obter forte união de resinas compostas à dentina era considerado um grande desafio, foi proposto por Asmussen e Munksgaard, em 
1983, um novo conceito objetivando conseguir a interação química de agentes resinosos com a porção orgânica da dentina ${ }^{7}$. Toda a história desta linha de investigação tendo como objeto principal o adesivo Gluma se inicia praticamente com o trabalho de destes autores, em 1984, onde estudaram o efeito de um aldeído, no caso, o formaldeído, como agente de ligação entre o colágeno e a resina adesiva ${ }^{8}$. Logo em seqüência, no mesmo ano, surge a primeira publicação utilizando-se o glutaraldeído como parte integrante de um sistema de união ${ }^{58}$.

A utilização de aldeídos foi sugerida por Asmussen e equipe, uma vez que a dentina não oferecia condições ideais para adesão, por ser um substrato que continha grande quantidade de água. Neste contexto, quimicamente os aldeídos podem reagir em meio aquoso com componentes moleculares que compõem o colágeno ${ }^{6,59,60}$. O mecanismo proposto pode ser acompanhado pela figura 2.4.A. O aldeído atacaria grupos amina pendentes da molécula de colágeno, onde um complexo hidroxi-alquil é formado. $\mathrm{Na}$ presença de um monômero resinoso contendo um radical hidrogênio ativo, como o hidrogênio do radical hidroxila do monômero HEMA, dá-se a reação com o complexo hidroxialquil, onde uma molécula de água é liberada como subproduto. Logo, teríamos a união entre a resina adesiva com o colágeno, mediada pelo aldeído ${ }^{6,58,83}$.

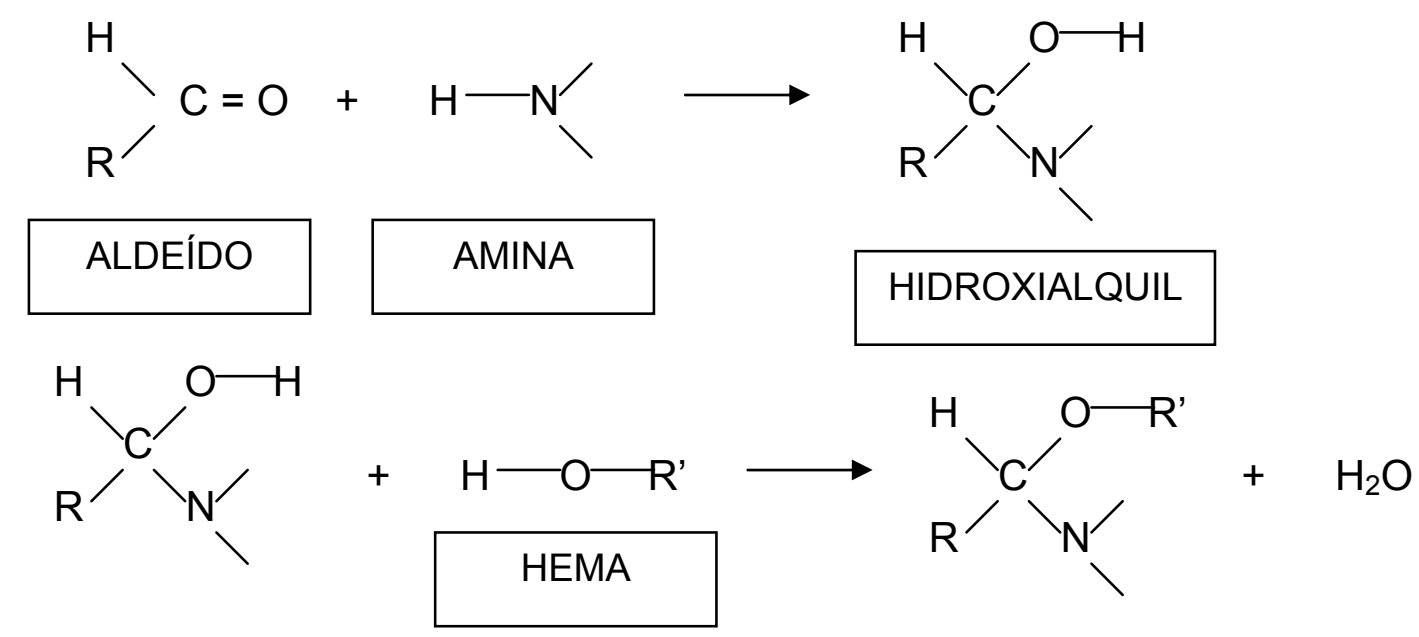

Fig. 2.4.A - Mecanismo de reação entre aldeído, proteína e HEMA, conforme declarado por Munksgaard (1986). (Adaptado de Ruyter, 1992 ${ }^{83}$ ) 
A opção definitiva de se usar o glutaraldeído foi motivada a partir do trabalho de Asmussen e Munksgaard de $1985^{6}$. Neste trabalho, foram testados uma série de adesivos constituídos por misturas de aldeídos alifáticos ou heteroaromáticos combinados com monômeros ativos em meio aquoso. Estes adesivos eram aplicados sobre a dentina seca, previamente condicionada por EDTA. Decorrido 1 minuto, a superfície dentinária era seca novamente e uma resina fluida para esmalte era aplicada. Ensaios de resistência a tração em dentina e análise de formação de fendas em cavidades também feitas em dentina, foram os determinantes escolhidos.

Quando aldeídos alifáticos eram utilizados, menores eram os resultados de resistência de união e, dentre os aldeídos alifáticos, os melhores resultados foram obtidos com as combinações de aldeído propiônico e glutaraldeído, sendo que o glutaraldeído apresentou melhores resultados com relação à prevenção de fendas marginais devido à contração de polimerização de resina restauradora.

Avaliando-se também a concentração de glutaraldeído e de HEMA, os autores reportaram que misturas de $5 \%$ para $35 \%$, respectivamente, em água $(60 \%)$, foram as que obtiveram os mais altos valores de resistência à tração.

Os trabalhos desta linha de pesquisa que se sucederam procuraram otimizar a resistência de união, através de estudos sobre o condicionamento da dentina e a simplificação dos passos, justificada pela tendência de mercado. Neste âmbito, a formulação original do Gluma foi modificada algumas vezes, como podemos verificar na Tabela 2.4 . 
Tabela 2.4 - Diversas formulações comerciais do sistema Gluma, segundo informações dos fabricantes

\begin{tabular}{|c|c|c|c|c|}
\hline Formulação & $\begin{array}{l}\text { N.o de } \\
\text { passos }\end{array}$ & Ácido & Primer & Adesivo \\
\hline $\begin{array}{l}\text { Gluma - } \\
\text { original }\end{array}$ & 4 & $\begin{array}{l}\text { Ácido } \\
\text { fosfórico } 37 \% \\
\text { (esmalte) }+ \\
\text { EDTA 0,5M } \\
\text { (dentina) } \\
\end{array}$ & $\begin{array}{c}\text { Solução aq. de } \\
\text { glutaraldeído + } \\
\text { HEMA }\end{array}$ & Bis-GMA + TEGDMA \\
\hline Gluma 2000 & 3 & $\begin{array}{l}\text { Solução de } \\
\text { oxalato de } \\
\text { alumínio + } \\
\text { glicina } \\
\text { (esmalte e } \\
\text { dentina) }\end{array}$ & $\begin{array}{c}\text { Solução aq. de } \\
\text { glutaraldeído + } \\
\text { HEMA }\end{array}$ & Bis-GMA + TEGDMA \\
\hline Gluma CPS & 3 & $\begin{array}{c}\text { Ácido } \\
\text { fosfórico } 20 \% \\
\text { (esmalte e } \\
\text { dentina) } \\
\end{array}$ & $\begin{array}{c}\text { Solução aq. de } \\
\text { glutaraldeído + } \\
\text { HEMA }\end{array}$ & Bis-GMA + TEGDMA \\
\hline $\begin{array}{l}\text { Gluma Solid } \\
\text { Bond }\end{array}$ & 3 & $\begin{array}{c}\text { Ácido } \\
\text { fosfórico a } \\
20 \%\end{array}$ & $\begin{array}{l}\text { Etanol, HEMA, } \\
\text { TEGDMA, ácido } \\
\text { maléico, ácido } \\
\text { maléico mono-2- } \\
\text { metacriloil-oxyéster, } \\
\text { anidrido maléico, } \\
\text { 2,3-Bornandion, } \\
\text { água }\end{array}$ & $\begin{array}{c}\text { TEGDMA, Bisphenol A- } \\
\text { bis(hydroxypropylmetacrilato), } \\
\text { ácido maléico, ácido maléico } \\
\text { mono-2-metacriloil-oxyéster, } \\
\text { anidrido maléico, 2,3- } \\
\text { Bornandion, HEMA, 2-(n- } \\
\text { Buthox)etil-4- } \\
\text { dimetilaminobenzoato, 2,2- } \\
\text { dimethoxy-1,2-difenil-etan-1- } \\
\text { on, ácido metacrílico, } \\
\text { hidroxitolueno butilado }\end{array}$ \\
\hline $\begin{array}{l}\text { Gluma One } \\
\text { Bond }\end{array}$ & 2 & $\begin{array}{c}\text { Ácido } \\
\text { fosfórico a } \\
20 \%\end{array}$ & - & $\begin{array}{l}\text { UDMA, HEMA, acetona, 2-(n- } \\
\text { Buthox)etil-4- } \\
\text { dimetilaminobenzoato, 2,3- } \\
\text { Bornandion, hidroxitolueno } \\
\text { butilado }\end{array}$ \\
\hline $\begin{array}{l}\text { Gluma } \\
\text { Comfort } \\
\text { Bond }\end{array}$ & 2 & $\begin{array}{c}\text { Ácido } \\
\text { fosfórico a } \\
20 \%\end{array}$ & - & $\begin{array}{c}\text { Etanol, HEMA, } \\
\text { diuretanodimetacrilato, ácido } \\
\text { maléico, 2-(nButoxy)etil-4- } \\
\text { dimetacrilato, 2,3-Bornandion, } \\
\text { 4-META, água }\end{array}$ \\
\hline $\begin{array}{l}\text { Gluma } \\
\text { Comfort } \\
\text { Bond + } \\
\text { Desensitizer }\end{array}$ & 2 & $\begin{array}{c}\text { Ácido } \\
\text { fosfórico a } \\
20 \%\end{array}$ & - & $\begin{array}{l}\text { Etanol, HEMA, } \\
\text { diuretanodimetacrilato, ácido } \\
\text { maléico, 2-(nButoxy)etil-4- } \\
\text { dimetacrilato, 2,3-Bornandion, } \\
\text { 4-META, glutaraldeído, água }\end{array}$ \\
\hline
\end{tabular}

A utilização do EDTA ao invés de ácidos fortes devia-se praticamente ao receio de se prejudicar o órgão pulpar, uma vez que era observado que seu padrão de desmineralização apresentava a não desobstrução dos túbulos dentinários, além de possuir $\mathrm{pH}$ relativamente neutro. Passado o receio, a técnica do condicionamento total (esmalte + dentina) tomou conta do mercado e, outras soluções ácidas mais fortes foram testadas com o Gluma, como solução de oxalato de alumínio com aminoácidos incorporados ${ }^{2,5}$. Tal modificação gerou um relativo 
aumento de resistência de união, que culminou no lançamento do Gluma 2000. Testes com o ácido fosfórico também foram realizados, culminando em novas formulações do sistema ${ }^{4,66}$. Interessante é que, com lançamento do Gluma Solid Bond, o sistema perde sua essência, que seria promover a união química entre colágeno e resina através da interação entre os componentes glutaraldeído e HEMA. Podemos reparar que o glutaraldeído já não fazia mais parte da formulação (Tabela 2.4). Entretanto, o fabricante ainda continuava comercializando a formulação básica do primer, sob o nome de Gluma Desensitizer que, como o próprio nome já indica, era indicado para desensibilização dentinária.

É de conhecimento que aldeídos formam ambas ligações intramoleculares e intermoleculares com moléculas de proteínas, resultando na formação de hetropolímeros de maior rigidez estrutural. A reação de aldeídos com proteínas acontece por reações de condensação com grupos amina para a formação de $\alpha$ hidroxiaminas, as quais podem condensar com novos grupamentos amina para efetivar as ligações cruzadas ${ }^{36}$.

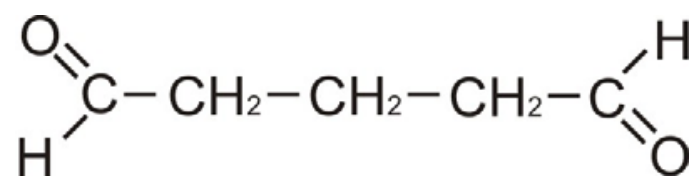

Figura 2.4B - Fórmula estrutural do glutaraldeído $\left(\mathrm{C}_{5} \mathrm{H}_{8} \mathrm{O}_{2}\right)$. Sinônimos: 1,3-diformilpropano, glutaral, glutardialdeído, dialdeído glutárico, 1,5-pentanedial, 1,5-pentanedione, ácido glutaraldeído potencial. CAS No. 111-30-8

O glutaraldeído, na realidade, trata-se de um dialdeído alifático de 5 carbonos, de estrutura relativamente simples (Figura 2.4B) e de peso molecular de 100,13 . É caracterizado por sua baixa viscosidade, sendo prontamente solúvel em água e em solventes orgânicos, como etanol, benzina e éter. Possui temperatura de congelamento de $-14^{\circ} \mathrm{C}$, ponto de fusão em torno de $60^{\circ} \mathrm{C}(1 \mathrm{mmHg})$, pressão de vapor de 0,1160 a $25^{\circ} \mathrm{C}$, gravidade específica de $1.064 \mathrm{~g} / \mathrm{mL}$ e densidade de vapor de 3,4. É estável à luz mas oxida em exposição ao ar e polimeriza quando aquecido. Em solução, o glutaraldeído existe em equilíbrio sob formas de glutaraldeído livre, hemiidratos, diidratos e cis e trans isômeros do hemiacetal cíclico $^{36,45,64}$. 
Dentre todos os reagentes fixadores conhecidos, o glutaraldeído é o mais eficaz na preservação de finas estruturas, devido ao potencial de formar ligações cruzadas rapidamente, efetivamente e irreversivelmente com proteínas sem ocorrer coagulação das mesmas. O glutaraldeído reage com grupamentos $\alpha$-amina de aminoácidos, $\mathrm{N}$-terminais de grupamentos $\alpha$-amina de peptídeos e grupamentos sulfídricos de cisteína. O local predominante de reação com proteínas é o grupamento $\varepsilon$-amina da molécula de lisina, embora reações também podem ocorrer com tirosina, histidina e resíduos sulfídricos ${ }^{10,36}$.

O glutaraldeído vem sendo utilizado em alguns campos de pesquisa como na engenharia de tecidos biológicos e a engenharia de biomateriais. Sua capacidade de promover ligações cruzadas entre peptídeos, tem sido aplicada como coadjuvante em reparos, regeneração guiada de tecidos ósseos (osteocondutores), no desenvolvimento de biopróteses e tratamento de válvulas cardíacas $^{12,23,39,44,46,53,115}$.

\subsection{A Adesão em dentina 'seca'}

Atualmente a estratégia mais aceita para adesão ao tecido dentinário está baseada nos princípios da "adesão úmida", proposta por Kanca III em 1992 ${ }^{42,43}$. Neste contexto, grande parte dos materiais promotores de adesão, os chamados agentes de união (ou simplesmente sistemas adesivos) foram reformulados para se adequarem a esta tendência.

A adesão úmida se fundamenta na utilização de primers (soluções preparadoras) contendo monômeros resinosos previamente à aplicação de uma resina fluida. Tais primers são capazes de provocar a evaporação da água presente na camada de dentina desmineralizada, e assim, facilitando a penetração dos monômeros resinosos. Com a penetração destes monômeros, a dentina desmineralizada tem sua tensão superficial alterada para níveis receptivos para o molhamento pela resina fluida, seja hidrofóbica ou hidrofílica.

No entanto, esta técnica encontra problemas como dificuldade dos monômeros preencherem toda a camada de dentina desmineralizada ${ }^{84}$ e, especificamente na clínica, dificuldade para o profissional estabelecer o padrão ideal de umidade dentinária para a correta realização do processo ${ }^{107}$. Estudos recentes apontam também uma dificuldade por parte dos sistemas adesivos de se 
interagirem de um modo mais íntimo com a trama de colágeno exposta, ocasionando numa incompleta cobertura (ou revestimento) dessa trama ${ }^{90,91,113}$.

A estratégia de adesão com dentina "desidratada" ou "seca", embora reservada por algum tempo, despertou nova atenção recentemente. Antes, há de se clarificar que tais termos utilizados, seja "desidratada" ou "seca", refere-se ao aspecto visual da superfície dentinária (dentina desmineralizada) após secagem, e não sua desidratação por completo. No passado, esta condição de substrato tornava impraticável a adesão com a formação de camada híbrida, devido à secagem excessiva da dentina desmineralizada resultar num colapso de até $65 \%$ em volume da trama de colágeno ${ }^{22}$. Esta condição diminui a permeabilidade da dentina, dificultando a infiltração dos agentes de união ${ }^{69}$. No entanto, há estudos que demonstram que a trama de colágeno colapsada é capaz de re-expandir-se completamente após seu re-umedecimento com água ${ }^{22,70}$. Devido ao seu ideal parâmetro de solubilidade e a alta capacidade de realizar pontes de hidrogênio, a água quebra as ligações interpeptídeos entre as fibras da trama colágena colapsada e re-organiza os espaços interfibrilares, preenchendo-os ${ }^{19,67}$.

Percebe-se que o controle da umidade da superfície dentinária é crucial para os demais procedimentos na técnica úmida, estando diretamente relacionada com a manutenção dos espaços interfibrilares das moléculas de colágeno pós desmineralização.

Diferentes solventes (exceto a água) tornam-se objetos de grande interesse no intuito de criar-se um modelo de adesão com uma mínima ou nula participação de água, visando melhorar propriedades mecânicas e longevidade. Neste campo, foi demonstrada a habilidade de certos solventes (como metanol, etanol e acetona) de enrijecer a matriz de colágeno ${ }^{54}$, ocorrendo uma relativa estabilização da estrutura, mesmo após a evaporação do solvente ${ }^{19}$. O enrijecimento da matriz, porquanto aumentando seu módulo de elasticidade e estabilidade, podem ser fatores favoráveis à manutenção dos espaços intra e inter fibrilares para a penetração resinosa sem interferência da água.

Ainda, Carvalho et al. em $2003^{19}$, especularam que solventes dessa categoria podem também contribuir para a re-expansão do colágeno em estado de relativo colapso. Dependeria da capacidade desses solventes em quebrar as ligações entre as fibrilas (pontes de hidrogênio), re-estabelecendo os espaços antes ocupados pelos minerais, à semelhança da água. Tal capacidade estaria ligada ao valor do parâmetro de solubilidade de cada solvente. 
Neste caminho, podemos citar o trabalho de Pashley et al. de $2000^{70}$, no qual demonstraram a capacidade de uma solução de glutaraldeído em enrijecer a camada de dentina desmineralizada, verificando um aumento significativo de seu módulo de elasticidade. Semelhantemente ao glutaraldeído, outros agentes de ligação cruzada estão sendo estudados, como a proanthocianidina e genipin, e aumentos significantes em termos de resistência à tração da dentina desmineralizada têm sido observados ${ }^{11}$. O fortalecimento e aumento das propriedades mecânicas das fibras colágenas expostas, podendo diminuir sua susceptibilidade à degradação enzimática ${ }^{75}$, constitui-se um objeto de grande interesse para a odontologia restauradora.

Entretanto, a literatura pertinente ainda carece de estudos mais elucidativos, com mais aplicabilidade em condições clínicas. Nos trabalhos de Pashley et al. ${ }^{70}$ (2000) e Maciel et al. ${ }^{54}$ (1996) , tais melhoras das propriedades da dentina desmineralizada foram observadas após longos períodos de imersão em diversas soluções, ao menos 10 minutos. Por outro lado, Nör et al. ${ }^{66}$ (1996), ao verificar as propriedades da dentina desmineralizada, imergindo-a em solução de glutaraldeído a $5 \%$ por cinco minutos, não obteve diferenças significantes (resistência a tração e módulo de elasticidade) comparado com o grupo controle, solução tampão fosfato. Porém, tais conclusões servem de base para a investigação do comportamento desses reagentes como substâncias promotoras de adesão em dentina seca e em tempo clinico hábil. 


\section{Proposição}

Considerando a necessidade de aprimoramento de materiais e/ou técnicas que objetivem a qualidade de adesão em substrato dentinário, neste tópico, apresentam-se as propostas de investigação científica, motivadas após a minuciosa revisão da literatura. 



\section{PROPOSIÇÃO}

Compreender e resolver os problemas bucais é o anseio de todo pesquisador de Odontologia. Isto não seria diferente para os da área de Materiais Dentários. A curiosidade que move os pesquisadores em relação ao desenvolvimento de materiais para adesão em dentina decorre das dificuldades de interação que estes apresentam em relação ao próprio tecido dentinário e também ao meio bucal, impulsionando trabalhos há mais de quatro décadas.

Somente a linha de pesquisa em que o presente trabalho se encaixa apresenta cerca de 20 anos. Contudo, ainda continua estimulante. No decorrer deste período, grandes avanços foram alcançados como se observa na literatura. Trabalhos não só envolvendo adesão em si, mas também trabalhos preocupados com a dinâmica da dentina frente aos materiais testados e o aprofundamento do conhecimento biológico e fisiológico desse tecido, foram responsáveis em mudar muitas vezes a estratégia adesiva.

O adesivo Gluma, por sinal, já apresentou diversas formulações, sempre acompanhando a evolução do conhecimento e até a tendência de mercado. Entretanto, o mecanismo químico de adesão a que se propunha o sistema foi desacreditado, tendo sido tarjado como ineficiente.

Por outro lado, e de acordo com a evolução da ciência, este sistema ainda desperta curiosidade. Questiona-se que a formulação do adesivo Gluma possa ser adequada aos novos conhecimentos e, acredita-se inclusive, que possa contribuir para resolver alguns dos problemas enfrentados atualmente. A análise isolada de seu componente primordial, o glutaraldeído, pode trazer algumas respostas.

Neste contexto, e após o devido estudo da literatura pertinente, foi gerada a motivação para a realização de um trabalho com as seguintes proposições:

1- Avaliar a resistência de união à dentina humana, proporcionada por sistemas adesivos experimentais que apresentam ou não um primer de glutaraldeído em sua composição.

2- Avaliar a influência da umidade dentinária em relação aos valores de resistência de união obtidos pelos sistemas adesivos experimentais, quando aplicados pelas técnicas úmida e seca de adesão à dentina.

3- Observar microscopicamente o padrão de formação da camada híbrida obtida pelos diversos sistemas de união. 
E perante às propostas acima, foram elaboradas as seguintes hipóteses nulas a serem testadas:

1- Não há diferença entre os valores de resistência de união entre resina restauradora e dentina quando uma solução aquosa de glutaraldeído é aplicada como primer dentinário durante o processo de aplicação do agente adesivo.

2- Não há diferença entre os valores de resistência de união, quando a aplicação do sistema adesivo se dá em condições de dentina úmida ou seca. 
Materiais e
métodos 



\section{MATERIAIS E MÉTODOS}

\subsection{Materiais selecionados para este estudo:}

Tabela 4.1.a - Materiais selecionados

material composição

\begin{tabular}{|c|c|}
\hline Aluminas para polimento (Arotec, São & Dióxido de alumínio em suspensão \\
\hline Paulo, SP, Brasil) & aquosa, corantes \\
\hline $\begin{array}{l}\text { Etanol absoluto } \\
\text { (Merck KGaA, Darmstadt, Alemanha) }\end{array}$ & Etanol p.a. $99,9 \%$ pur. $\left(\mathrm{H}_{2} \mathrm{O} \leq 0,1 \%\right)$ \\
\hline $\begin{array}{l}\text { Etch-37 condicionador ácido gel a } 37 \% \\
\text { (Bisco Inc., Schaumburg, IL, EUA) }\end{array}$ & Ácido ortofosfórico a 37\%, Goma Xantana \\
\hline $\begin{array}{l}\text { Glutaraldeído a } 50 \% \\
\text { (Electron Microscopy Sciences, Ft. } \\
\text { Washington, PA, EUA) }^{\mathrm{a}}\end{array}$ & $\begin{array}{c}\text { Solução de glutaraldeído a 50\% em água } \\
\text { destilada, purificado (nível Microscopia } \\
\text { Eletrônica) }\end{array}$ \\
\hline
\end{tabular}

(Fluka Chemicals - Sigma-Aldrich Chemie 2-hidroxietilmetacrilato, >99\% de pureza

$\mathrm{GmbH}$, Steinheim, Alemanha) ${ }^{a}$

Lixas abrasivas de carbeto de silício

Norton, Brasil

Loctronic

Acetona (95-100\%), iniciadores (N,N-

(Henkel-Loctite - SP, Brasil) $^{a}$

dialquiltoluidina) (0,1-1\%).

Adper Scotchbond Multi-purpose adhesive

Bis-GMA, HEMA, fotoiniciadores,

$(3 M-E S P E, \text { St. Paul, MN, EUA })^{b}$ estabilizadores

Timol (cristais)

Pharmácia Specífica, Bauru, Brasil

Bis-GMA, TEGDMA, fotoiniciadores,

Z100 (3M ESPE) $)^{\mathrm{b}}-\operatorname{cor} \mathrm{A} 2$ estabilizadores, partículas de óxido de zircônia/sílica coloidal (66\%p.v.)

Adesivo de cianoacrilato Zapit (Dental

Ventures of America Inc., Corona, CA,

\section{Etilcianoacrilato}

EUA)

Papel filtro absorvente (Melitta do Brasil

Inc., São Paulo, SP, Brasil)

N.I. ${ }^{\mathrm{C}}$

Pincéis aplicadores Scotchbond Multiuso

(3M-ESPE)

N.I.

a: informação do fabricante; b: Paul et al. $(1999)^{76}$; N.I.: não informado. 
Tabela 4.1.b - Identificação do lote e prazo de validade dos principais materiais

\begin{tabular}{lcc}
\hline materiais & lote & vencimento \\
\hline Etch-37 & 0500004535 & $03-2008$ \\
Adper Scotchbond adhesive & $5 \mathrm{PA}$ & $02-2008$ \\
Z100 & 4 YE; 4YF; 5FN & $02-2007 ; 02-2007 ; 09-2008$ \\
Zapit (base) & L20A & N.I. \\
Loctronic & $01 \mathrm{DE} 254$ & $04 / 2006$ \\
Glutaraldeído a 50\% & 530807 & Ind. \\
HEMA & $454398 / 1$ & Ind. \\
\hline
\end{tabular}

Obs: N.I.: não informado; Ind.: indeterminado.

\subsection{Preparo das soluções experimentais:}

a) Primer A: Solução aquosa de glutaraldeído $(\mathrm{pH} 7,0)$

A partir da solução de glutaraldeído a $50 \%$, foi titulada uma solução de $5 \%$ adicionando-se água destilada. $\mathrm{O}$ pH desta nova solução foi ajustado para 7,0 adicionando-se $\mathrm{NaOH}$, e utillizando-se de um pHmetro para aferição (B371, Micronal, São Paulo, SP, Brasil).

b) Primer B: Solução de HEMA e etanol

Este primer foi preparado utilizando-se a concentração de $35 \%$ de HEMA e $65 \%$ de etanol absoluto em peso, medidos numa balança digital de precisão de milésimos de grama (Bel engineering SRL, Monza, Itália). $\mathrm{O}$ pH aferido foi de 6,8.

\subsection{Avaliação de resistência de união:}

a) Obtenção do substrato dentinário

24 dentes terceiros-molares humanos superiores extraídos foram selecionados para este estudo. A modo de obtenção desses dentes foi submetido à análise pelo Comitê de Ética da Faculdade de Odontologia de Bauru (processos 031/2004, 051/2005). Após extração, os dentes foram armazenados em solução aquosa de timol a $0,1 \%$ até o momento do uso; tempo que não se excedeu em seis meses. 
b) Preparo do substrato para adesão

A superfície oclusal dos dentes foi planificada através de desgaste por lixas de granulação de número 150 e 320, em lixadeira mecânica (300 rpm) com refrigeração, expondo a dentina média coronária. A camada de detritos (ou smear layer) foi padronizada através de lixas de número 600 , por 10 segundos.

c) Definição e delineamento dos grupos de estudo

O total de dentes foi dividido igualmente em quatro grupos de seis dentes, a saber:

Grupo GS: Neste grupo a seguinte seqüência foi utilizada durante o procedimento adesivo em dentina:

Condicionamento: Ataque com ácido a 37\% (Etch-37) por $15 \mathrm{~s}$, lavagem por $20 \mathrm{~s}$ e secagem com papel absorvente para manutenção de umidade superficial aparente (superfície brilhante a olho nu).

Tratamento preparador da superfície: - Aplicação ativa com pincel do primer A de glutaraldeído por 1 minuto e secagem com papel absorvente, mantendo-se a umidade superficial aparente;

- Aplicação ativa com pincel do primer B de HEMA/etanol por 30 s; aguarda-se mais $30 \mathrm{~s}$ para melhor evaporação do solvente.

Aplicação do adesivo: Aplicação ativa com pincel do componente adesivo (resina fluida) do sistema Adper Scotchbond Multiuso por $15 \mathrm{~s}$, seguida de fotopolimerização por $20 \mathrm{~s}$ através de um aparelho fotopolimerizador de lâmpada halógena que oferece $500 \mathrm{~mW} / \mathrm{cm}^{2}$ de potência (Degulux soft-start, Degussa, $\mathrm{GmbH}$, Alemanha), verificados previamente por um 'radiômetro' (model 100, Demetron Research Co., Danbury, CT, EUA).

Grupo S: A seqüência do procedimento adesivo deste grupo apenas difere da do grupo GS no tocante a não aplicação do primer A de glutaraldeído. Neste caso, após a lavagem do gel ácido condicionador, a dentina foi imediatamente seca com tiras de papel absorvente e foi também aplicado um jato de $\operatorname{ar}\left(80 \mathrm{lbs} / \mathrm{pol}^{2}\right)$ por $3 \mathrm{~s}$ a cerca de $10 \mathrm{~cm}$ de distância. Deste ponto em diante, seguiram-se os mesmos procedimentos descritos para grupo GS.

Grupo GU: Os espécimes pertencentes a este grupo foram tratados conforme o grupo GS, exceto que a aplicação do primer B de HEMA/etanol foi feita pela técnica úmida (Kanca III, 1992 $2^{42,43}$ ), isto é, a dentina desmineralizada não foi 
desidratada, ou seja, apenas o excesso de umidade superficial foi removido com o auxílio de tiras de papel absorvente.

Grupo U: Neste grupo, também não se utilizou o primer A experimental baseado em glutaraldeído, e a aplicação dos outros componentes se deu respeitando-se a técnica úmida para adesão, assim como no grupo GU.

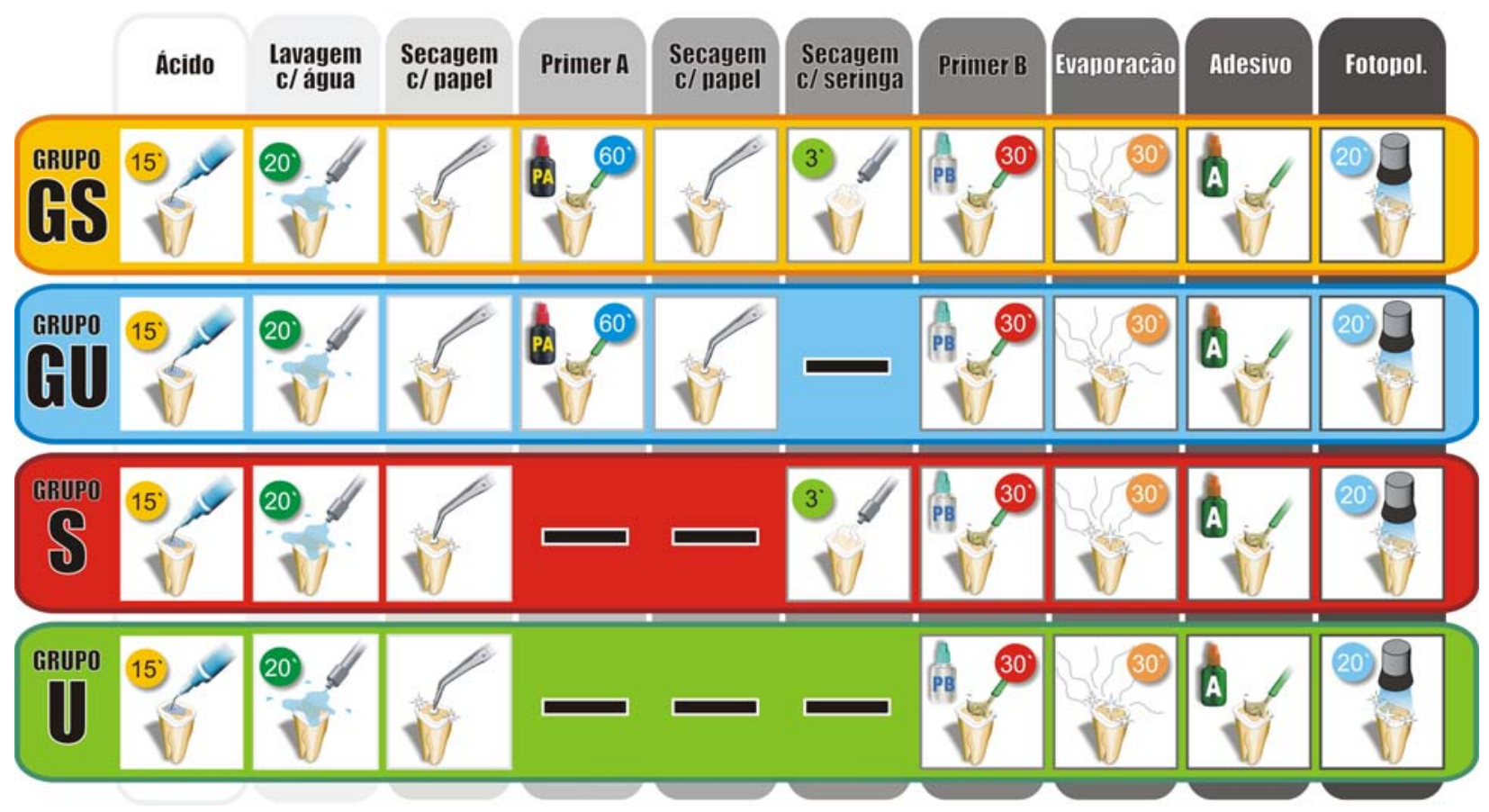

Fig. 4.3 - Esquematização representativa dos dos procedimentos adesivos adotados para cada grupo

d) Preparo dos espécimes para o ensaio de resistência de união

Um bloco de resina fotopolimerizável (Z100) de cerca de $4 \mathrm{~mm}$ de altura foi construído para cada dente. Esta estrutura foi realizada em camadas, sendo que cada uma foi fotopolimerizada por $40 \mathrm{~s} / 500 \mathrm{~mW} / \mathrm{cm}^{2}$ ininterruptos (Degulux softstart). Em seguida, eles foram armazenados em água deionizada a $37^{\circ} \mathrm{C}$ por $24 \mathrm{~h}$. Posteriormente, utilizando-se um disco diamantado (South-Bay Tech, San Clemente, CA, EUA) adaptado a uma máquina de cortes precisos (South-Bay Tech) os dentes foram seccionados em série, longitudinalmente e nos sentidos mésiodistal e vestíbulo-lingual , originando palitos de resina-adesivo-dentina de 0,8 $\times 0,8$ $\mathrm{mm}$ de espessura. A área de secção dos palitos, portanto, perfazia 0,64 mm². Palitos contendo traços visíveis de esmalte a olho nú ou que apresentassem tecido dentinário de comprimento inadequado (menor que $2 \mathrm{~mm}$ ) foram descartados. 
e) Ensaios de resistência de união

Cada palito foi fixado com adesivo comercial de cianoacrilato (Zapit) ao dispositivo de micro-tração e foi submetido à força de tração em máquina de ensaios universais (EMIC DL 500, São José dos Pinhais, PR, Brasil), na velocidade de $0,5 \mathrm{~mm} / \mathrm{min}$ até ocorrência de ruptura de união. Os valores obtidos em $\mathrm{kgf}$ (quilograma-força) pelo equipamento foram convertidos em unidade MPa (megaPascal) através da medição imediata da área adesiva dentinária submetida ao teste com paquímetro digital de precisão de centésimo de milímetro (modelo 727, Starret, Brasil).

f) Forma de análise dos resultados

Para a análise estatística dos dados de resistência de união foi utilizado o teste de normalidade de Kolmorogov-Smirnov, seguida da análise de variância a um critério e o teste post-hoc de Tukey. O nível de significância adotado foi de $5 \%$.

\subsection{Microscopia eletrônica:}

a) Observação do modo de fratura

Todas as porções dentinárias dos palitos submetidos ao teste de tração foram montadas em stubs (plataforma de análise para MEV) e levadas ao metalizador (MED 1010, Balzers Union, FL, Liechtenstein) para receberem uma cobertura de aproximadamente $10 \mathrm{~nm}$ de ouro. Os stubs preparados foram observados em microscópio eletrônico de varredura (Leo 435VP, Leo Electron Microscopy Ltd., Cambridge, Inglaterra) com o objetivo de se determinar o padrão característico de fratura. A presença de esmalte na área adesiva também foi investigada e, palitos que se enquadravam com essa característica foram descartados e tiveram seus dados removidos do teste de resistência.

Aumentos de 100X, ou mais, até 1500X quando necessário, foram utilizados. As fraturas foram classificadas em adesiva, mistas e coesivas, como segue:

Adesiva $(A)$ : fratura ocorrida na região da camada de adesivo ou camada híbrida, seja topo, corpo ou base.

Mistas: fratura ocorrida em duas ou mais regiões, seja em dentina, resina composta ou região adesiva. São subdivididas em: $M R$ : mista, com parciais fraturas 
adesiva e coesiva em resina; $M D$ : mista, com parciais fraturas adesiva e coesiva em dentina; MRD: mista, com parciais fraturas adesiva e coesiva em resina e em dentina;

Coesivas: fratura ocorrida somente em resina ou somente em dentina. São subdivididas em: CR: $100 \%$ coesiva em resina; CD: 100\% coesiva em dentina.

b) Preparo para observação da morfologia da camada híbrida

Assim como para o teste de resistência de união, dentes terceiros-molares humanos superiores foram selecionados e submetidos ao tratamento adesivo conforme os grupos estudados. Uma camada de $2 \mathrm{~mm}$ de resina composta foi adicionada sobre o adesivo, polimerizada e os dentes permaneceram $24 \mathrm{~h}$ a $37^{\circ} \mathrm{C}$ em água deionizada. Os dentes foram cortados com disco diamantado (South Bay Tech) transversalmente em relação ao seu longo-eixo de modo a obter-se discos com $1 \mathrm{~mm}$ de dentina remanescente. Estes discos ainda foram cortados longitudinalmente para a obtenção dos espécimes para a avaliação microscópica da área adesiva em vista longitudinal. Esta área dos espécimes recebeu acabamento e polimento manuais, utilizando-se lixas de números 600, 1000, 1200 e 2500 por 20 s em água corrente e suspensões de alumina (Arotec) de granulações 0,3 $\mu \mathrm{m}, 0,05 \mu \mathrm{m}$ com auxílio de uma flanela especial de polimento (DP-NAP Struers, Copenhagen, Dinamarca). Para a remoção da camada de detritos formada, a área polida foi tratada com ataque ácido (Etch-37) por $15 \mathrm{~s}$ e lavada com água deionizada por $30 \mathrm{~s}$. Em seguida os espécimes foram imersos em solução de $\mathrm{NaOCl}$ a $2 \%$ por 1 minuto.

Os espécimes foram montados em stubs, secos em estufa dentro de dessecador e metalizados para observação em MEV.

\section{c) Forma de análise}

A análise deu-se de maneira qualitativa, observando-se o grau de interdifusão do adesivo e qualidade da camada híbrida formada, de acordo com parâmetros registrados na literatura específica. Estes incluem, dentre outros, a presença de porosidades, profundidade de penetração, formação e qualidade morfológica dos prolongamentos resinosos, formação e espessura da camada híbrida.

Todos os procedimentos acima foram realizados pelo mesmo operador. $\mathrm{O}$ preparo dos dentes e aplicação dos sistemas adesivos utilizados foram feitos em ambiente com temperatura e umidade relativa controladas, ou seja, $23^{\circ} \mathrm{C} \pm 1$ e $50 \%$ 
\pm 10 respectivamente, conferidos através de higrômetro de fio de cabelo e termômetro de coluna de mercúrio (Fischer, Alemanha). 
Resultados 



\section{RESULTADOS}

Os resultados individuais, de resistência e modo de fratura de todos os espécimes testados no presente trabalho se encontram na seção de anexos.

\subsection{Dados de resistência de união e análise estatística}

Na tabela 5.1 acham-se os dados referentes ao teste de resistência de união. Após realizados a análise de variância e o teste de Tukey (Tabela 5.1.b), verifica-se que os grupos GS e GU apresentaram-se diferentes em termos de médias de resistência de união em relação aos grupos $S$ e $U(p \leq 0,05)$. Isto indica que o uso do glutaraldeído (primer $A$ ) influenciou significativamente nos resultados de resistência de união. Entre GS e GU e entre $S$ e $U$, não foi observado diferença estatística $(p>0,05)$, indicando que a condição de umidade dentinária (úmido ou seca) não teve influência sobre a resistência de união.

Tabela 5.1.a - Médias de resistência de união, desvio padrão e comparativo de Tukey

\begin{tabular}{ccccc}
\hline Grupos & $\mathbf{n}$ & Resistência de união - MPa (dp) & \multicolumn{2}{c}{ Tukey } \\
\hline GS & 98 & $58,8(27,2)$ & $\mathrm{a}$ & \\
GU & 88 & $56,8(23,6)$ & $\mathrm{a}$ & \\
S & 108 & $47,1(19,3)$ & & $\mathrm{b}$ \\
U & 101 & $42,1(17,6)$ & & $\mathrm{b}$
\end{tabular}

Obs.: n: número de espécimes; dp: desvio-padrão; Tukey: letras iguais indicam não haver diferença estatística

Tabela 5.1.b - Teste de Tukey $(\alpha=0,05)^{*}$

\begin{tabular}{ccccc}
\hline Grupos & GS & GU & S & U \\
\hline GS & - & 0,9858 & 0,0031 & 0,0000 \\
GU & 0,9858 & - & 0,0179 & 0,0001 \\
S & 0,0031 & 0,0179 & - & 0,3847 \\
U & 0,0000 & 0,0001 & 0,3847 & - \\
\hline
\end{tabular}

a= nível de significância adotado. 
Visualiza-se no gráfico 5.1, os valores de resistência adesiva, desvio-padrão e aspecto da distribuição amostral de cada grupo estudado.

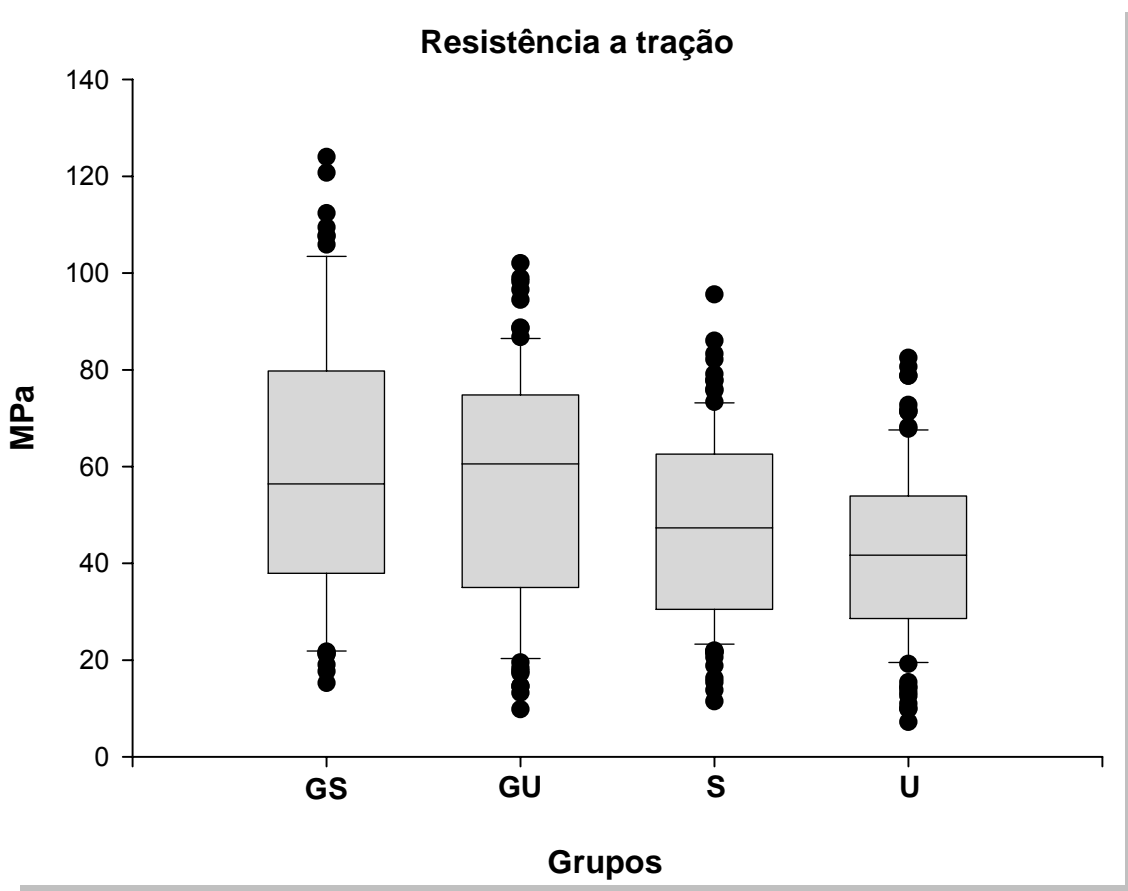

Fig. 5.1 - Gráfico tipo box-plot onde visualiza-se os valores médios de resistência de união, distribuição amostral e desvio padrão em função de cada grupo estudado

\subsection{Análise microscópica}

a) Padrão de fratura

Através da tabela 5.2 constata-se que a maioria das fraturas observadas foi do tipo adesiva, seguida por uma razoável porcentagem de fraturas do tipo mista com presença de resina (MR) e pelas demais, minoritárias. Fraturas do tipo coesiva em resina $(C R)$ e coesiva em dentina $(C D)$ foram raramente observadas. 
Tabela 5.2 - Classificação das fraturas observadas em MEV

\begin{tabular}{cccccccc}
\hline Grupos & \multicolumn{9}{c}{ Tipo de fratura $^{\mathrm{a}}$} & & & \\
& A & MR & MD & MRD & CR & CD & total \\
\hline S & $62(57 \%)^{\mathrm{b}}$ & $37(34 \%)$ & $4(4 \%)$ & $5(5 \%)$ & 0 & 0 & $\mathbf{1 0 8}$ \\
U & $58(57 \%)$ & $27(27 \%)$ & $14(14 \%)$ & $2(2 \%)$ & 0 & 0 & $\mathbf{1 0 1}$ \\
GS & $56(57 \%)$ & $26(27 \%)$ & $7(7 \%)$ & $8(8 \%)$ & $1(1 \%)$ & 0 & $\mathbf{9 8}$ \\
GU & $55(62 \%)$ & $12(14 \%)$ & $16(18 \%)$ & $4(4 \%)$ & $1(1 \%)$ & 0 & $\mathbf{8 8}$ \\
\hline
\end{tabular}

$a_{\text {: tipos de fratura: A: 100\% adesiva; MR: mista, com parciais fraturas adesiva e coesiva em }}$ resina; MD: mista, com parciais fraturas adesiva e coesiva em dentina; MRD: mista, com parciais fraturas adesiva e coesiva em resina e em dentina; CR: $100 \%$ coesiva em resina; CD: $100 \%$ coesiva em dentina. ${ }^{\text {b }}$ : porcentagem da ocorrência da respectiva fratura no total.

b) Fotomicrografias em MEV, representativas da análise do padrão de fratura.

Aumento do original e voltagem utilizados aparecem no rodapé de cada imagem. $R=$ resina; $T H=$ topo da camada híbrida; $D=$ dentina; $C H=$ camada híbrida; $B H=b a s e$ da camada híbrida; E=esmalte.

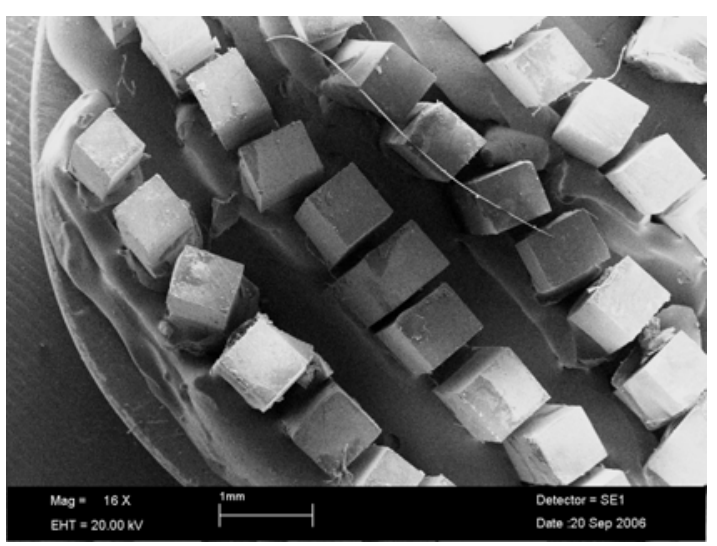

Fig. 5.2.1 - Imagem representativa de um stub, contendo os palitos que tiveram sua área adesiva examinada.

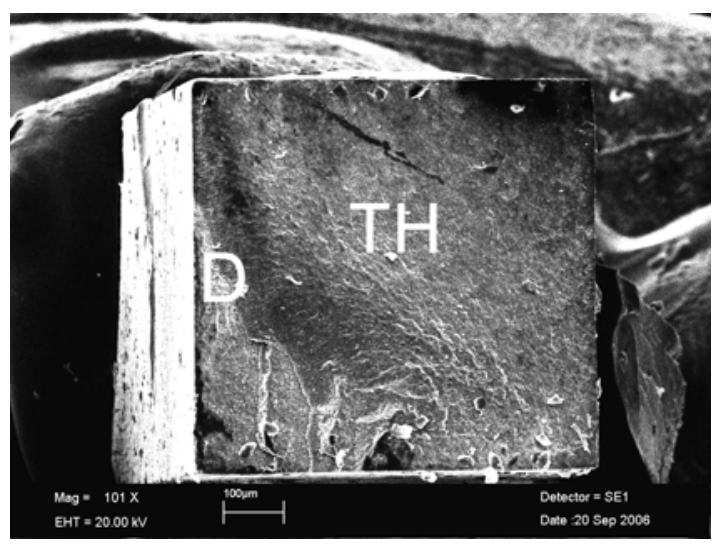

Fig. 5.2.3.a - Imagem representativa de espécime apresentando fratura do tipo MD.

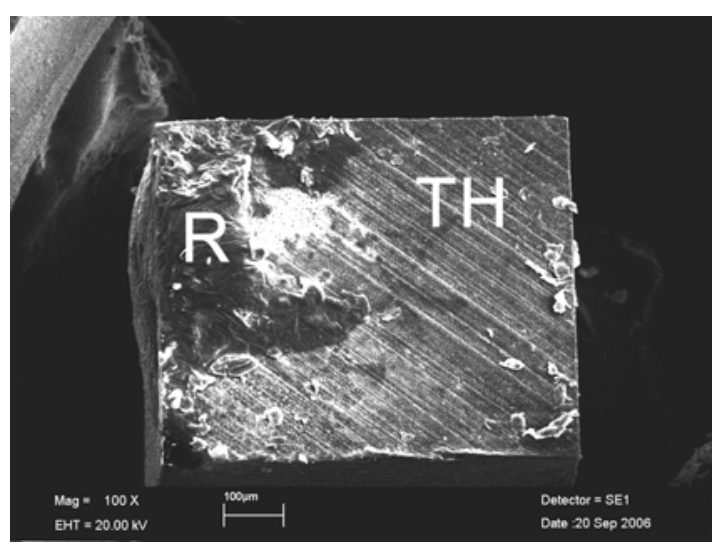

Fig. 5.2.2 - Imagem representativa de espécime apresentando fratura do tipo MR.

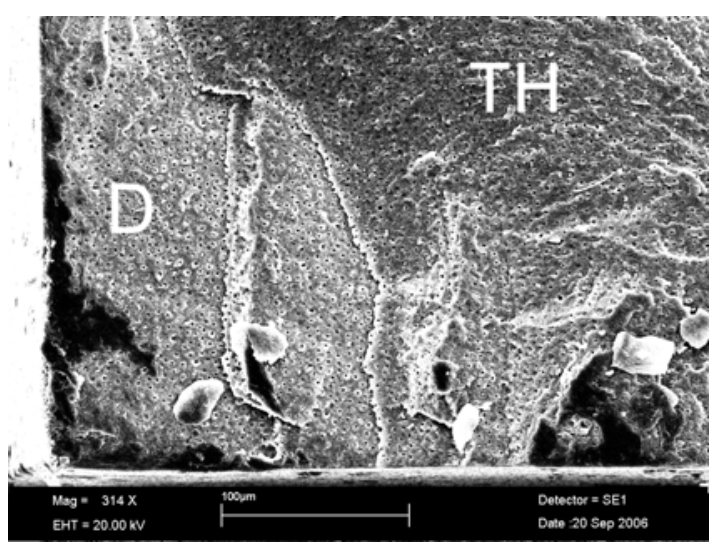

Fig. 5.2.3.b - Maior aumento da imagem anterior. Nota-se a fratura na camada híbrida e em dentina. 


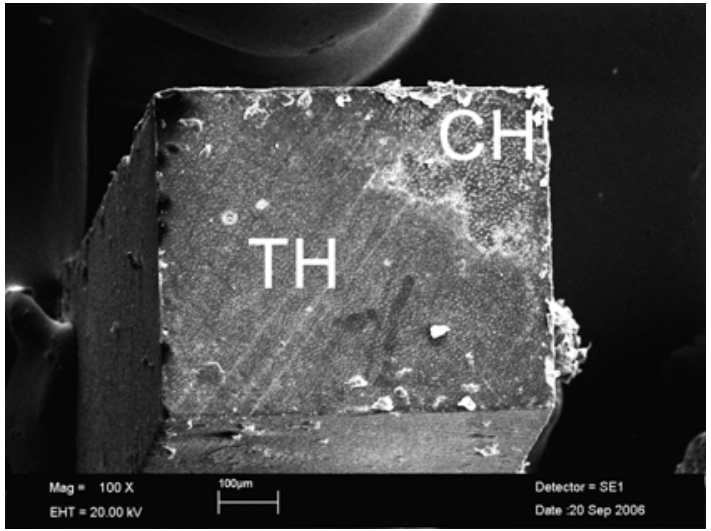

Fig. 5.2.4 - Imagem representativa de espécime apresentando fratura do tipo $A$. Nota-se fratura na camada híbrida, em topo e corpo.

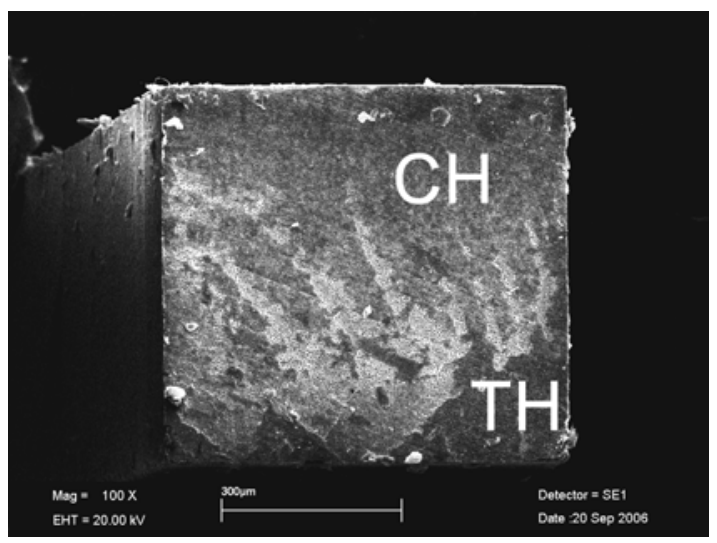

Fig. 5.2.6.a - Imagem representativa de espécime apresentando fratura do tipo $A$. Nota-se fratura na camada híbrida, em topo e corpo.

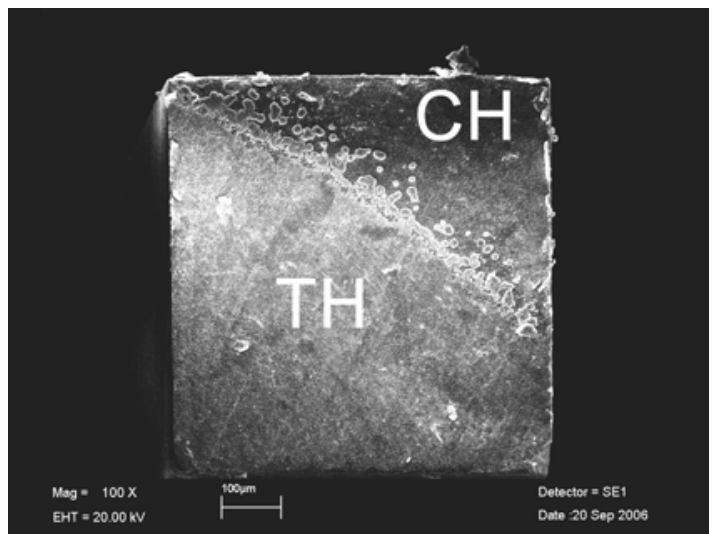

Fig. 5.2.7.a - Imagem representativa de espécime apresentando fratura do tipo $A$. Nota-se fratura na camada híbrida, em topo e corpo.

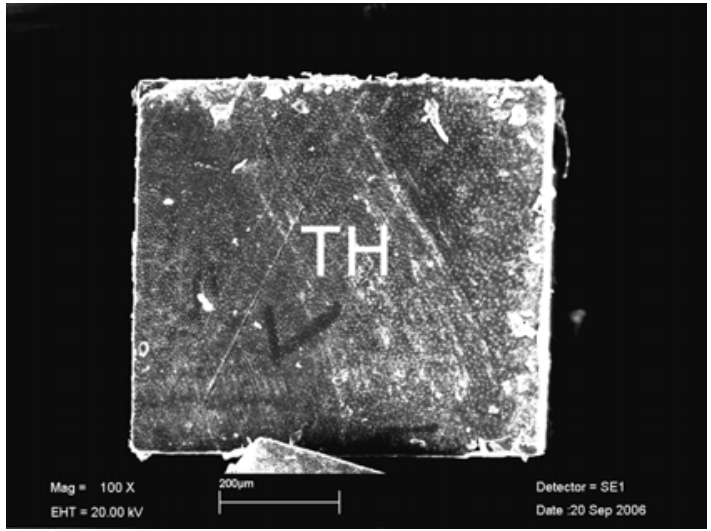

Fig. 5.2.5 - Outra imagem representativa de espécime apresentando fratura do tipo $\mathrm{A}$. Nota-se fratura completa em topo da camada híbrida.

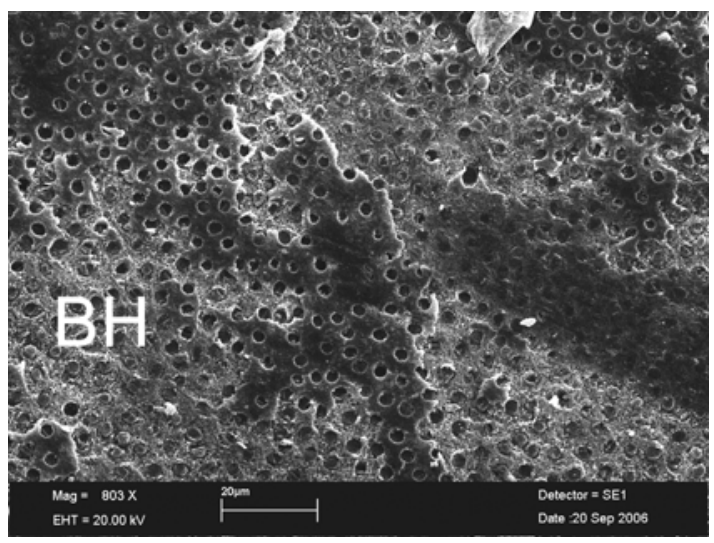

Fig. 5.2.6.b - Maior aumento da imagem anterior. Nota-se também fratura em base de camada híbrida.

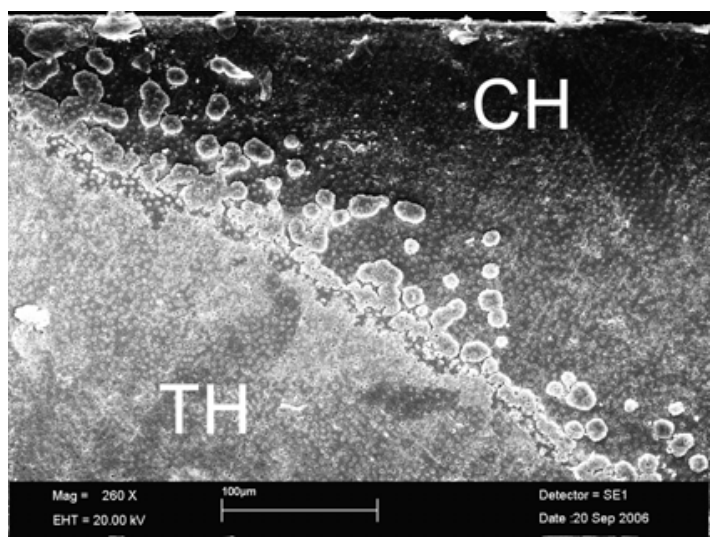

Fig. 5.2.7.b - Maior aumento da imagem anterior, para confirmação. 


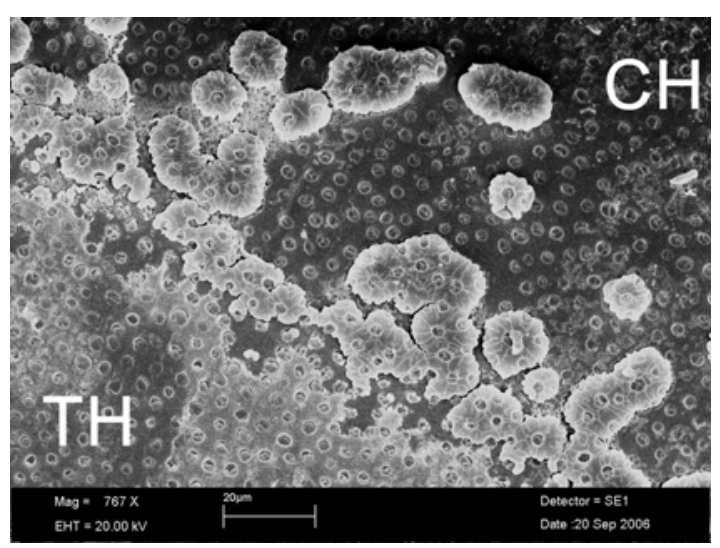

Fig. 5.2.7.c - Maior aumento da imagem anterior.

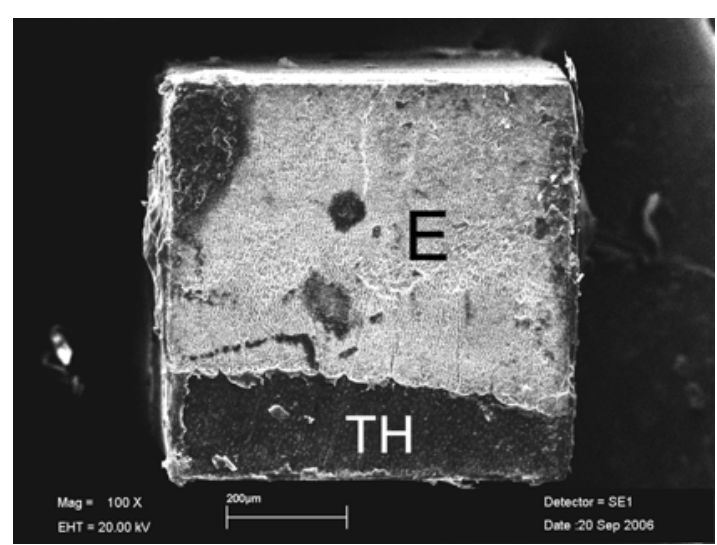

Fig. 5.2.8 - Imagem representativa de espécime apresentando presença de esmalte na área adesiva.

c) Fotomicrografias em MEV, representativas da zona de interdifusão resinosa em dentina, de cada grupo estudado. $H=$ =camada híbrida; $R=$ =resina composta; $T=$ tag; $D=$ dentina.

De uma maneira geral, foi possível observar que todos os grupos estudados foram eficazes na formação da camada híbrida, não havendo diferenças consideráveis dentro das limitações que a microscopia eletrônica de varredura apresenta. Todos apresentaram a formação de numerosos prolongamentos resinosos ou tags, com comprimento chegando a 30-50 $\mu \mathrm{m}$. A espessura da camada híbrida observada ficou em torno de 2 a $4 \mu \mathrm{m}$. Pode-se observar também que os túbulos foram bem preenchidos pela resina, inclusive promovendo a anastomose entre vizinhos, pela difusão através de seus canais laterais.
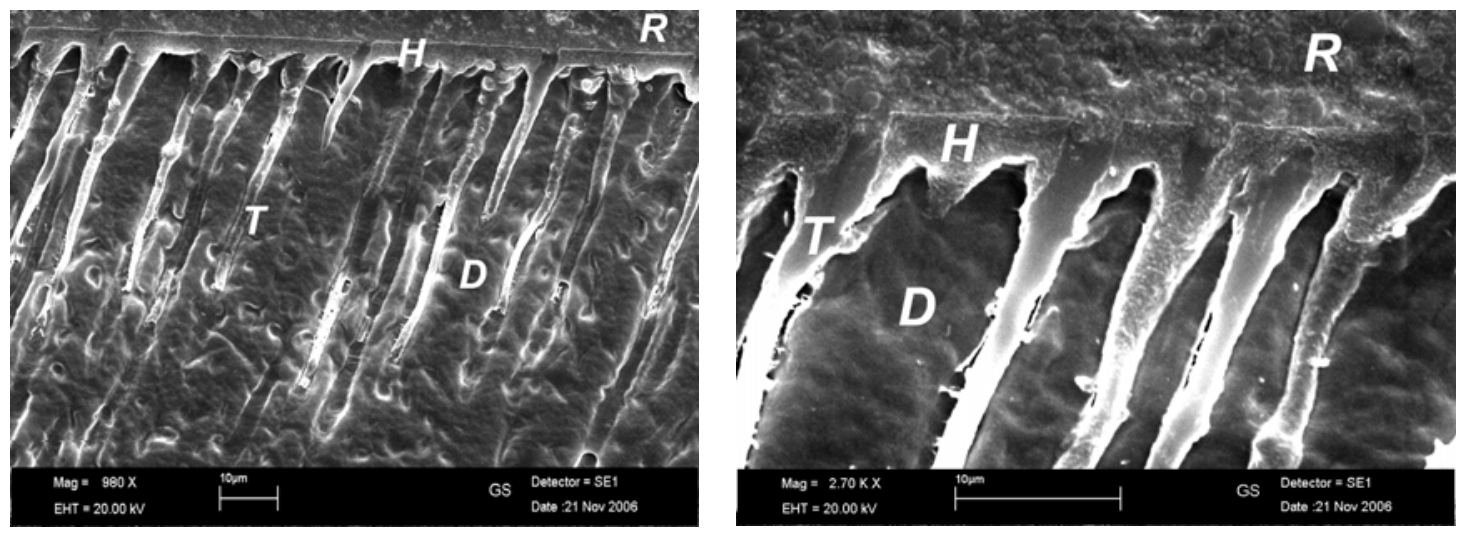

Fig. 5.2.9 - Grupo GS: a) Fotomicrografia representativa da camada híbrida formada; b) Maior aumento. R: resina composta; $\mathrm{H}$ : camada híbrida; $\mathrm{D}$ : dentina; $\mathrm{T}$ : prolongamentos resinosos. 

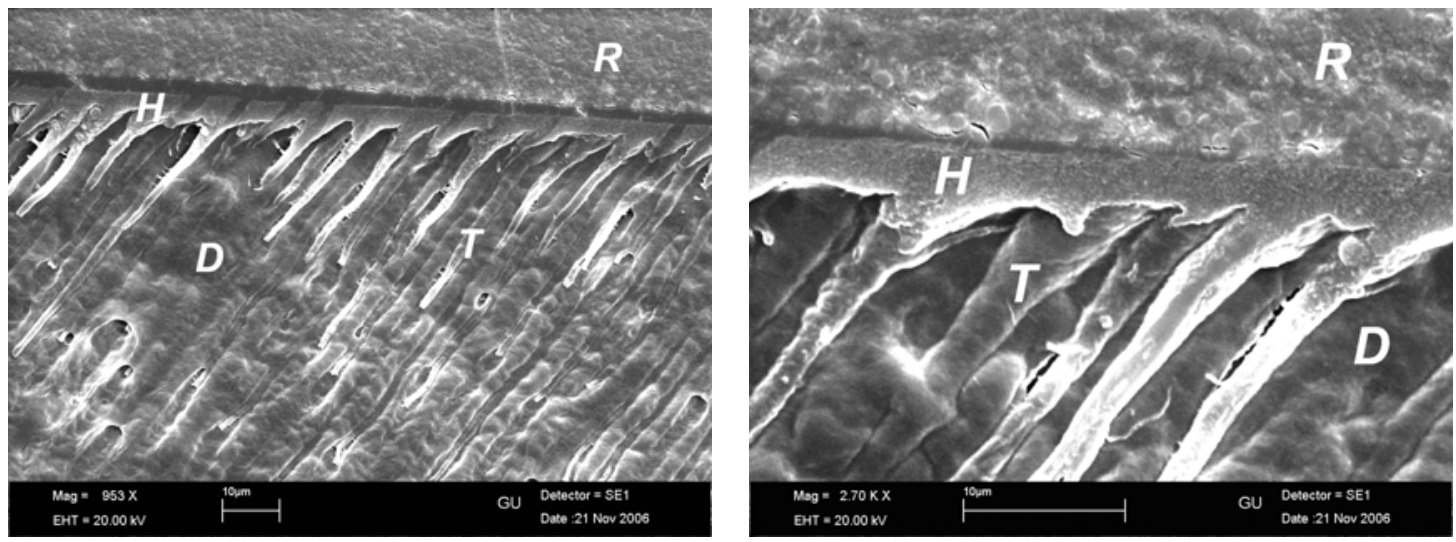

Fig. 5.2.10 - Grupo GU: a) Fotomicrografia representativa da camada híbrida formada; b) Maior aumento. R: resina composta; H: camada híbrida; D: dentina; T: prolongamentos resinosos.
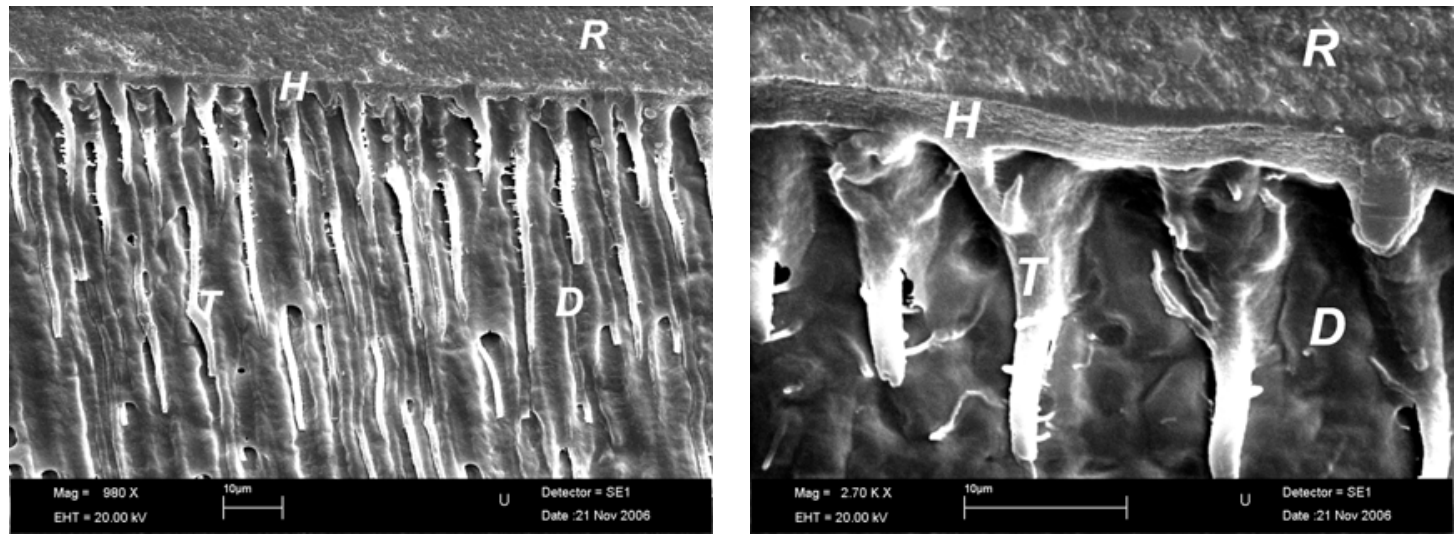

Fig. 5.2.11 - Grupo U: a) Fotomicrografia representativa da camada híbrida formada; b) Maior aumento. R: resina composta; H: camada híbrida; D: dentina; T: prolongamentos resinosos.
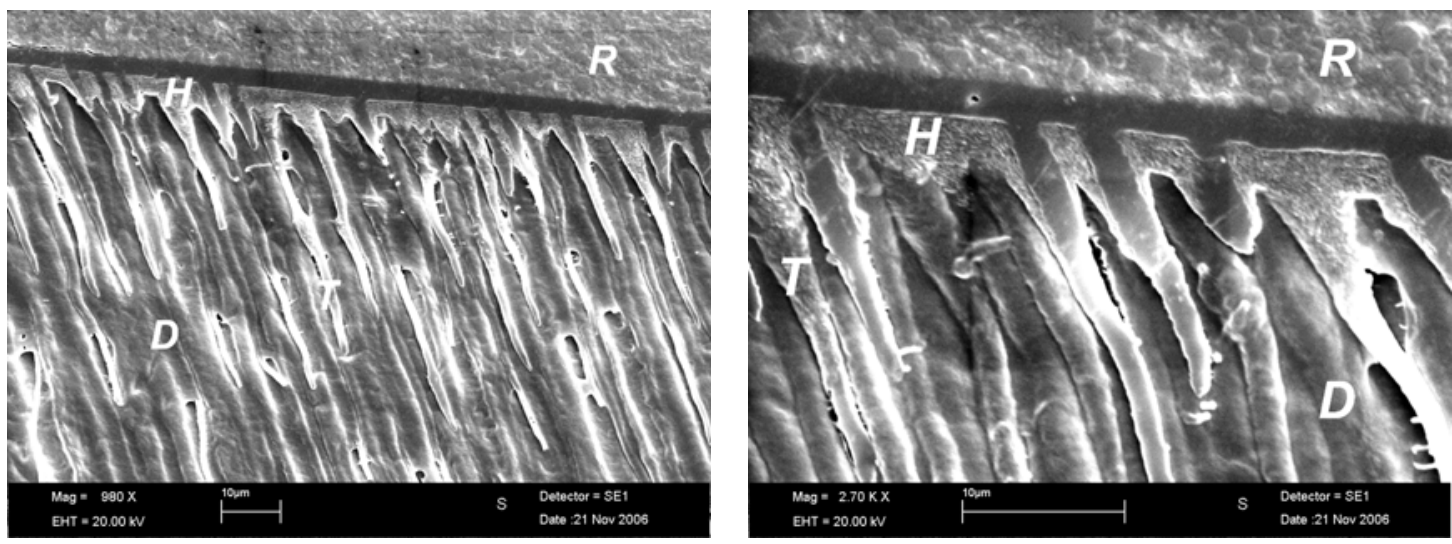

Fig. 5.2.12 - Grupo S: a) Fotomicrografia representativa da camada híbrida formada; b) Maior aumento. R: resina composta; H: camada híbrida; D: dentina; T: prolongamentos resinosos. 


\section{Discussão}

Neste tópico, foi abordada a discussão relativa aos resultados obtidos em nosso estudo, assim como aquela pertinente à metodologia empregada, confrontando com os achados de outros trabalhos da literatura que apresentassem relações de semelhança ou de controvérsia.

Não foi a intenção desta discussão prender-se em análises profundas de metodologias de outros trabalhos como as já exploradas no tópico Revisão da Literatura, devido à possibilidade de desvio de objetividade.

Também, as dificuldades encontradas e algumas observações em relação à metodologia foram consideradas, no intuito de contribuir para estudos futuros. 



\section{DISCUSSÃO}

Os resultados demonstram que a aplicação do glutaraldeído como primer dentinário teve influência significante na resistência de união entre resina restauradora e dentina in vitro. Nos grupos nos quais o glutaraldeído foi empregado, valores significativamente maiores foram encontrados, fato que nos permite rejeitar a primeira hipótese nula proposta.

O uso do glutaraldeído como componente de adesivos dentinários teve início com os trabalhos de Asmussen e Munksgaard, por volta de $1985^{6,59,60}$, com a introdução do sistema Gluma. Naquele período, a contribuição esperada dos componentes era de se realizar a união química entre a parte orgânica da dentina intertubular e a resina adesiva. Tal sistema utilizava-se do condicionamento da dentina com EDTA, cujo intuito era remover apenas a camada de detritos superficial (smear layer on). Comprovou-se por estes trabalhos que tal interação entre os componentes principais do Gluma era possível em meio aquoso, o que seria relevante para a aplicação em dentina, um substrato inerentemente úmido. $O$ Gluma inicialmente apresentava baixos valores de resistência adesiva (provavelmente devido ao alto conteúdo de água na formulação), contudo, nos mesmos padrões dos outros sistemas de união dentinários da época. Com a evolução do conhecimento, sobretudo das propriedades físico-mecânicas do substrato dentinário, o sistema Gluma sofreu diversas reformulações (Tabela 2.4).

Embora teoricamente bem descrito, o mecanismo de união química através da interação entre colágeno, glutaraldeído e HEMA não fora extensivamente investigado. A existência dessa união química chegou a ser desacreditada no meio científico, ou se realmente existisse, considerou-se que contribuiria em pouco para a resistência de união em dentina ${ }^{69,92}$.

O glutaraldeído é uma substância química conhecida pela capacidade de criar ligações cruzadas entre moléculas de proteínas, sendo muito utilizado, desde a década de 1960, nos preparos de tecidos biológicos em estudos de microscopia ótica e eletrônica ${ }^{45}$. Como a dentina desmineralizada é composta essencialmente de colágeno, é esperado que a aplicação de glutaraldeído venha a modificar as propriedades dessa estrutura. Trabalhos como o de Maciel et al. ${ }^{54}$ (1996) e Pashley et al. ${ }^{70}$ (2000) demonstram a efetividade de uma solução aquosa de glutaraldeído a $5 \%$ em aumentar o módulo de elasticidade da dentina desmineralizada. Entretanto, o tempo de exposição do colágeno à ação da solução nesses trabalhos foi longo, 
cerca de 10, 30 e 60 minutos. Tay et al. ${ }^{95}$ (1997) observaram ultra-estruturalmente (MET) os efeitos causados pela aplicação de um adesivo baseado em acetona (One-Step, Bisco) em dentina desmineralizada, que foi previamente tratada com solução de glutaraldeído a $8 \%$ por 15 minutos. Nesse estudo, a solução de glutaraldeído foi aplicada em dentina seca por jato de ar de $3 \mathrm{~s}$, que foi novamente seca da mesma maneira antes da aplicação do adesivo. Os autores notaram zonas de pobre infiltração do adesivo na interface dente-restauração e compactação das fibrilas colágenas desmineralizadas. Também relataram que quando a matriz dentinária seca e tratada com glutaraldeído era reumedecida com água, os padrões ultra-estruturais não se alteravam, ou seja, a dentina fixada não poderia se reexpandir novamente com o reumedecimento. Importante ressaltar-se que em tal estudo a aplicação do glutaraldeído foi feita em dentina desmineralizada previamente seca e, portanto, um certo grau de colapso das fibrilas colágenas possivelmente já era existente antes da fixação, diferentemente do que foi realizado no presente trabalho. Adicionalmente, como demonstrado por Maciel ${ }^{54}$, o alto conteúdo de acetona presente no adesivo utilizado, além de favorecer o enrijecimento da matriz de fibrilas (que provavelmente já se encontravam em estado de colapso), não contribui positivamente para a re-expansão da mesma.

Dados adicionais sobre a influência do glutaraldeído nas propriedades mecânicas da dentina desmineralizada foram recentemente publicados por BedranRusso et al. ${ }^{11}$ (2007). Interessante foi notar que o glutaraldeído não obteve sucesso na melhoria das propriedades, contrariamente ao observado no presente trabalho. Até o momento, não foi possível encontrar as razões para essa divergência, embora o presente estudo não tenha avaliado diretamente ou especificamente as propriedades da dentina desmineralizada. Gage et al. ${ }^{33}$ (1989) explicam que o glutaraldeído possui a capacidade de fixar e enrijecer as moléculas de colágeno pela reação com grupos de aminoácidos livres, como as cadeias de lisina e arginina. Neste ponto específico, Ritter at al. ${ }^{81}$ (2001) demonstraram que a aplicação de uma solução aquosa de glutaraldeído/HEMA (5/35 \% em peso) em dentina bovina desmineralizada, reduz significativamente a quantidade de cadeias aminoácidas livres de lisina e discretamente as cadeias de hidroxilisina. Estes, os aminoácidos mais encontrados no colágeno tipo I. Assim como Munksgaard e Asmussen $^{58}$ (1984), os autores sugerem que os grupos $\varepsilon$-amino desses aminoácidos reagem com os grupamentos aldeídos presentes na molécula de 
glutaraldeído, formando bases de Schiff (ligações imino), gerando ligações cruzadas (Figura 2.4.A).

Pode-se concluir, diante dos trabalhos mencionados, que existem evidências sobre a capacidade do glutaraldeído em interagir com as moléculas de colágeno, modificando as propriedades da dentina desmineralizada. Especula-se que a fixação proporcionada pelo glutaraldeído ajude a manter a rede de fibrilas em estado de expansão, um importante pré-requisito para a posterior infiltração da resina adesiva. Entretanto, ainda se torna difícil afirmar algo sobre os efeitos do glutaraldeído na dentina desmineralizada em um curto período de aplicação, como o exigido durante a prática profissional. De acordo com o presente trabalho, o aumento da resistência de união verificado nos grupos GS e GU pode estar ligado à esta capacidade da solução de glutaraldeído em fixar, estabilizar e aumentar seu módulo de elasticidade da rede de fibras colágenas em tempo clínico viável.

A trama de colágeno em relativa expansão e enrijecida permitiria uma melhor penetração dos agentes resinosos por entre os espaços inter e intrafibrilares das moléculas de colágeno. A interação química entre glutaraldeído (combinado com as moléculas de colágeno) e HEMA pode favorecer este processo. Resumindo, supõem-se que a união química entre colágeno, glutaraldeído e HEMA proposta por Asmussen e Munksgaard ${ }^{6,58}$, induziria uma melhor afinidade entre resina adesiva e dentina desmineralizada, ajudando a resina a melhor recobrir e preencher os espaços entre as fibrilas. Neste aspecto, novos estudos como microscopia de transmissão eletrônica aliada à estudos de nanoinfiltração por nitrato de prata devem contribuir para melhor entendimento deste assunto em particular, complementando o presente estudo.

É importante destacar que a atenção da compra dos reagentes deste trabalho foi feita com cautela, tendo sido escolhido o glutaraldeído a $50 \%$ especial para estudos de microscopia. Diferentemente dos demais tipos, tidos como para uso técnico/laboratorial ou esterilização/desinfecção, a graduação especial para microscopia apresenta maior quantidade de monômeros e pequena quantidade de polímeros formados. Os de graduação técnica, por sua vez, consistem basicamente de moléculas poliméricas grandes, o que dificulta a penetração entre os tecidos e células, apresentando menor poder fixador ${ }^{45}$.

Segundo Nomura et al. ${ }^{65}$ (1977) a rigidez do colágeno aumenta à medida em que o conteúdo de água é retirado. É possível que parte da rigidez adquirida pela matriz dentinária após o tratamento com o glutaraldeído advenha do menor 
conteúdo de água ligado às moléculas de colágeno, uma vez que o glutaraldeído tenha ocupado esses espaços. Dessa forma, a matriz tratada com glutaraldeído poderia apresentar certa contração pela perda de água. Entretanto se realmente ocorrer, esta contração deve ser discreta, uma vez que isso prejudicaria a penetração posterior da resina adesiva com conseqüente queda de resistência de união ${ }^{69}$. Tal situação não se confirmaria com os resultados desse trabalho, se particularmente compararmos os valores de resistência entre os grupos com e sem a aplicação do glutaraldeído. As fotomicrografias obtidas em MEV (Figs. 5.2 .9 5.2.12) permitem verificar que os sistemas experimentais foram eficazes na formação da camada híbrida, nas duas situações, tanto em dentina úmida como em dentina seca. Observou-se a camada híbrida uniformemente composta em todos os grupos analisados, com formação de prolongamentos resinosos axiais extensos e prolongamentos laterais em grande número. Não foram encontrados indícios de contração da dentina desmineralizada, tendo em consideração as limitações da técnica.

Outro aspecto explorado no presente trabalho foi a questão da umidade dentinária. A água é o solvente de maior miscibilidade ao colágeno, apresentando parâmetro de solubilidade de Hansen para pontes de hidrogênio $\left(\delta_{\mathrm{h}}\left(\mathrm{J} / \mathrm{cm}^{3}\right)^{1 / 2}\right)$ de $37,3^{21}$. A preservação da umidade dentinária para a posterior desidratação por solventes constitui a essência da técnica úmida proposta por Kanca em 1992 ${ }^{42,43}$. Entretanto a presença da água durante o processo adesivo pode ser prejudicial à união, uma vez que esta pode combinar-se quimicamente com as resinas hidrofílicas presentes no primer e inibir a difusão de resinas hidrofóbicas para o interior da matriz colágena ${ }^{4,69,101}$. Como resultado, teríamos má composição da camada híbrida, diminuição das propriedades mecânicas e maior susceptibilidade à degradação ${ }^{84,98}$.

Pesquisas estão sendo desenvolvidas na direção de se encontrar um substituto da água durante o processo adesivo ${ }^{19,21,54,67}$. Segundo Pashley et al. ${ }^{68}$ (2001), solventes polares capazes de manter e re-expandir a matriz de colágeno devem possuir um $\delta_{\mathrm{h}}$ maior que 18,2, isto é, maior que o parâmetro de solubilidade do colágeno. Em contraste com a desidratação pela exposição ao ar, a desidratação química da matriz de colágeno por esta classe de solventes parece ser menos susceptível às forças de tensão superficial, devido à capacidade enrijecerem a matriz. Embora algum grau de contração seja esperado, a posterior 
re-expansão da matriz proporcionada pelos solventes pode minimizar esses efeitos, dependendo do solvente usado e do tempo de exposição ${ }^{54}$.

Os sistemas experimentais deste trabalho apresentaram um primer constituído de HEMA e etanol. O etanol apresenta $\delta_{\mathrm{h}}$ de 19.4 , sendo considerado um solvente com leve potencial de expansão do colágeno em comparação à solventes como o metanol $\left(\delta_{h}=22.3\right)$ e etilenoglicol $\left(\delta_{h}=26.0\right)$. No entanto, o trabalho de Carvalho et al. ${ }^{19}$ (2003) demonstrou que o primer dentinário de HEMA com etanol, dentre outras combinações testadas em dentina seca, permitiu os maiores valores de resistência de união com a resina restauradora e dentina, mediada pelo adesivo baseado em monômeros 4-META (Amalgambond, Parkell). Embora o trabalho de Carvalho et al. ${ }^{19}$ tenha falhado em estabelecer uma correlação positiva entre o parâmetro de solubilidade dos solventes e resistência adesiva em dentina, análises ultra-estruturais feitas (MET) comprovaram uma correlação positiva entre o parâmetro de solubilidade e o grau de manutenção do espaço entre as fibrilas da matriz de colágeno depois de realizado o processo de adesão.

É interessante destacar que Carvalho et al. ${ }^{19}$ (2003) acreditam que a manutenção dos espaços interfibrilares durante o procedimento adesivo seja mais relevante do que a própria capacidade de re-expansão da matriz colágena por parte dos solventes utilizados. Neste aspecto, o glutaraldeído, através do enrijecimento e fixação da trama de colágeno em ambiente aquoso (dentina úmida) poderia contribuir para a manutenção desses espaços. A aplicação posterior do primer baseado em etanol para a remoção do conteúdo de água também estaria ligada aos benefícios que este solvente poderia trazer, como relativa re-expansão e maior enrijecimento da trama durante a penetração resinosa.

A desidratação da dentina úmida pelo jato de ar de $3 \mathrm{~s}$ não resultou em queda de resistência adesiva. Isto requer a rejeição da segunda hipótese nula proposta. Como em MEV foi possível observar que todos os grupos apresentaram formação de camada híbrida uniforme, sugere-se que os sistemas utilizados são menos sensíveis à questão da manutenção da umidade dentinária. Do contrário, teríamos situações (grupos S e GS) em que a penetração resinosa teria sido prejudicada, pela secagem implicar diretamente na contração da rede de fibrilas colágenas. Entretanto, estudos ultra-estruturais mais específicos devem ser realizados no intuito de se adquirir melhor suporte científico.

Apesar da reação química entre HEMA e glutaraldeído ter como subproduto água (figura 2.4.A), sugere-se que a presença desta seja insignificante, uma vez 
que este subproduto está sendo formado durante exposição da dentina ao etanol. Sendo assim, teria como destino sua evaporação da superfície. Existe também a possibilidade de que o glutaraldeído diminua a permeabilidade dentinária pela fixação de proteínas presentes no fluido dentinário, como a albumina, reduzindo a condução deste fluido para a superfície, portanto, diminuindo a interferência da água. Acredita-se que esta é a forma de atuação do agente desensibilizante Gluma Desensitizer, com relativo sucesso no tratamento da sensibilidade dentinária ${ }^{24,26,49,87}$.

A secagem mais prolongada da dentina desmineralizada (jato de ar) teve também motivação no fato de observar seu comportamento frente à aplicação de um primer que não apresenta água entre seus componentes. Entende-se que tal informação pode ser relevante para estudos posteriores onde se pretenda desenvolver de sistemas totalmente hidrofóbicos. Resinas hidrofílicas, como as comumente utilizadas nos sistemas adesivos, são muito susceptíveis à degradação hidrolítica, tendo prognóstico de comportamento e durabilidade imprevisíveis em ambiente bucal ${ }^{34,99,100}$.

A dentina é um tecido de características ímpares, o que a torna desafiadora em relação à sua interação com materiais resinosos. O conhecimento aprofundado de seus constituintes, suas propriedades e funções, são aspectos determinantes para o sucesso do tratamento restaurador. Neste trabalho, buscou-se a compreensão das reações do tecido dentinário frente ao principal desafio de modificar suas características para torná-la mais receptiva à interação com componentes resinosos, ou seja, através da aplicação do glutaraldeído.

Pode-se dizer que novas evidências originaram-se em relação à efetiva contribuição do glutaraldeído durante o processo adesivo. Contudo, este tema necessita ser mais profundamente explorado afim de se verificar mais especificamente a interação dos componentes do sistema com a dentina desmineralizada. Não somente a resistência mas, a durabilidade da união deverá ser avaliada através de métodos indiretos e diretos. Estudos futuros como determinação do módulo de elasticidade da dentina desmineralizada, nanoinfiltração e análise em MET para verificação morfológica das fibrilas colágenas, devem complementar a avaliação do papel do glutaraldeído como componente de sistemas adesivos. Nesta linha, ainda torna-se interessante avaliar a influência da aplicação de sistemas adesivos contendo glutaraldeído em dentina afetada por cárie e cariada, na modificação das propriedades destes tecidos, 
inclusive no contexto da fixação de proteínas extracelulares que são expressas em processos de injúria ao complexo dentino-pulpar ${ }^{88}$.

Novos agentes de ligações cruzadas foram recentemente pesquisados por Bedran Russo et al. ${ }^{11}$ (2007) para o uso em dentina com o intuito de se estabilizar a rede colágena desmineralizada, como o genipin e o proanthocianidin. Provenientes de fontes naturais, demonstraram um grande potencial em aumentar a resistência à tração da dentina desmineralizada, podendo eventualmente servir como alternativa ao uso do glutaraldeído. 
Conclusões 



\section{CONCLUSÕES}

Tendo em vista o que foi proposto no presente estudo e tendo por base os resultados nele obtidos e respeitando-se suas limitações, pode-se concluir que:

1- O glutaraldeído, usado como um dos componentes de um sistema de união experimental influenciou significativamente na resistência de união em dentina, contribuindo com o aumento dessa propriedade.

2- O estado de secagem/umidade superficial da dentina desmineralizada não influenciou nos valores de resistência de união, de acordo com os parâmetros utilizados neste estudo.

3- Sugere-se a não aceitação da primeira e aceitação da segunda hipótese nula propostas.

\section{Nota final:}

Este trabalho contou em parte com o apoio financeiro da CAPES e do setor de Pós-Graduação da Faculdade de Odontologia de Bauru (PROAP). 



\section{Anexos}

Neste tópico encontram-se organizados os dados individuais colhidos durante a realização dos testes de resistência de união e análise do modo de fratura. Também, acham-se cópias dos documentos relativos à aprovação pelo comitê de ética em pesquisa. 

Anexo 1 - Tabelas 8.1 - Espessura, valores de resistência a tração em $\mathrm{kgf} \mathrm{e} \mathrm{em}$ MPa e tipo de fratura observada em MEV dos palitos obtidos de cada dente de acordo com seu respectivo grupo. Valores em negrito na base da tabela representam as médias. Valores tachados indicam espécime eliminado após confirmação, através de MEV, da presença de esmalte na área adesiva. GU, GS, S e U: grupos estudados; d: dente. A: 100\% adesiva; MR: mista, com parciais fraturas adesiva e coesiva em resina; MD: mista, com parciais fraturas adesiva e coesiva em dentina; MRD: mista, com parciais fraturas adesiva e coesiva em resina e em dentina; CR: 100\% coesiva em resina; CD: 100\% coesiva em dentina, E: presença de esmalte.

\begin{tabular}{ccccc}
\hline GU d1 & \multicolumn{5}{c}{$26 / 10 / 2005$} \\
\hline kgf & espessura (cm) & espessura 2 (cm) & MPa & Fratura \\
\hline 1,171 & 0,065 & 0,072 & 24,55 & $\mathrm{E}$ \\
0,817 & 0,071 & 0,071 & 15,89 & $\mathrm{E}$ \\
4,520 & 0,071 & 0,072 & 86,74 & $\mathrm{~A}$ \\
2,431 & 0,064 & 0,065 & 57,33 & $\mathrm{~A}$ \\
2,792 & 0,071 & 0,069 & 55,91 & $\mathrm{~A}$ \\
3,546 & 0,074 & 0,069 & 68,13 & $\mathrm{MR}$ \\
1,392 & 0,076 & 0,071 & 25,31 & $\mathrm{~A}$ \\
2,784 & 0,069 & 0,073 & 54,22 & $\mathrm{E}$ \\
4,306 & 0,075 & 0,083 & 67,86 & $\mathrm{~A}$ \\
3,753 & 0,069 & 0,066 & 80,85 & $\mathrm{CR}$ \\
3,572 & 0,075 & 0,074 & 63,14 & $\mathrm{E}$ \\
3,79 & 0,07 & 0,071 & 74,81 & $\mathrm{~A}$ \\
2,216 & 0,07 & 0,071 & 43,74 & $\mathrm{~A}$ \\
3,77 & 0,065 & 0,07 & 81,28 & $\mathrm{~A}$ \\
0,9832 & 0,076 & 0,072 & 17,63 & $\mathrm{MR}$ \\
3,032 & 0,079 & 0,07 & 53,79 & $\mathrm{~A}$ \\
0,8812 & 0,07 & 0,07 & 17,64 & $\mathrm{E}$ \\
3,437 & 0,077 & 0,073 & 59,98 & $\mathrm{MD}$ \\
3,291 & 0,07 & 0,075 & 61,49 & $\mathrm{MR}$ \\
& & & & \\
\hline $\mathbf{2 , 7 6 2}$ & $\mathbf{0 , 0 7 1}$ & $\mathbf{0 , 0 7 1}$ & $\mathbf{5 3 , 1 7}$ & \\
\hline & & & &
\end{tabular}

\begin{tabular}{ccccc}
\hline GU d2 & \multicolumn{5}{c}{$8 / 11 / 2005$} \\
\hline kgf & espessura (cm) & espessura 2 (cm) & MPa & Fratura \\
\hline 3,701 & 0,07 & 0,072 & 72,04 & MD \\
2,717 & 0,069 & 0,074 & 52,20 & MR \\
0,076 & 0,069 & 0,069 & 1,57 & MR \\
1,935 & 0,074 & 0,078 & 32,89 & A \\
2,505 & 0,067 & 0,071 & 51,66 & E \\
2,948 & 0,073 & 0,073 & 54,27 & A \\
3,051 & 0,073 & 0,069 & 59,42 & A \\
0,502 & 0,07 & 0,072 & 9,77 & A \\
1,152 & 0,065 & 0,066 & 26,34 & A \\
1,637 & 0,067 & 0,071 & 33,76 & A \\
2,073 & 0,069 & 0,072 & 40,93 & A \\
0,709 & 0,066 & 0,071 & 14,84 & E \\
0,6174 & 0,064 & 0,065 & 14,56 & MD \\
3,442 & 0,069 & 0,068 & 71,97 & E \\
3,731 & 0,067 & 0,073 & 74,83 & E \\
1,429 & 0,068 & 0,067 & 30,77 & A \\
1,676 & 0,067 & 0,071 & 34,56 & A \\
& & & & \\
\hline $\mathbf{1 , 9 9 4}$ & $\mathbf{0 , 0 6 9}$ & $\mathbf{0 , 0 7 1}$ & $\mathbf{3 9 , 7 9}$ & \\
\hline & & & & \\
\hline
\end{tabular}




\begin{tabular}{|c|c|c|c|c|}
\hline \multirow{2}{*}{$\frac{\mathrm{GU} \mathrm{d} 3}{\mathbf{k g f}}$} & \multirow[b]{2}{*}{ espessura (cm) } & \multicolumn{2}{|l|}{$10 / 11 / 2005$} & \multirow[b]{2}{*}{ Fratura } \\
\hline & & espessura $2(\mathrm{~cm})$ & $\mathrm{MPa}$ & \\
\hline 0,724 & 0,065 & 0,068 & 16,07 & $E$ \\
\hline 3,436 & 0,07 & 0,068 & 70,81 & A \\
\hline 2,566 & 0,072 & 0,068 & 51,41 & A \\
\hline 0,912 & 0,069 & 0,069 & 18,79 & E \\
\hline 0,957 & 0,066 & 0,076 & 18,72 & E \\
\hline 3,222 & 0,067 & 0,068 & 69,38 & A \\
\hline 1,079 & 0,07 & 0,065 & 23,26 & E \\
\hline 1,731 & 0,073 & 0,068 & 34,21 & $M D$ \\
\hline 2,726 & 0,07 & 0,068 & 56,18 & MD \\
\hline 1,082 & 0,071 & 0,074 & 20,20 & E \\
\hline 1,155 & 0,077 & 0,071 & 20,73 & E \\
\hline 4,032 & 0,067 & 0,071 & 83,15 & MD \\
\hline 3,892 & 0,072 & 0,071 & 74,69 & MD \\
\hline 0,9157 & 0,072 & 0,068 & 18,35 & MRD \\
\hline 2,593 & 0,073 & 0,074 & 47,09 & A \\
\hline 0,873 & 0,071 & 0,074 & 16,30 & $E$ \\
\hline 0,5285 & 0,071 & 0,072 & 10,14 & E \\
\hline 0,6842 & 0,075 & 0,068 & 13,16 & MD \\
\hline 2,362 & 0,075 & 0,075 & 41,19 & A \\
\hline 1,535 & 0,07 & 0,069 & 31,18 & MRD \\
\hline 2,26 & 0,073 & 0,07 & 43,39 & MD \\
\hline 1,134 & 0,073 & 0,074 & 20,59 & E \\
\hline 1,836 & 0,071 & 0,070 & 36,32 & \\
\hline
\end{tabular}

\begin{tabular}{|c|c|c|c|c|}
\hline GU d4 & & $16 / 11 / 2005$ & & \\
\hline kgf & espessura $(\mathrm{cm})$ & espessura $2(\mathrm{~cm})$ & $\mathrm{MPa}$ & Fratura \\
\hline 2,954 & 0,066 & 0,069 & 63,63 & A \\
\hline 1,078 & 0,065 & 0,066 & 24,65 & E \\
\hline 3,346 & 0,064 & 0,07 & 73,27 & A \\
\hline 1,014 & 0,066 & 0,074 & 20,37 & A \\
\hline 2,902 & 0,065 & 0,068 & 64,41 & A \\
\hline 2,432 & 0,067 & 0,063 & 56,52 & A \\
\hline 3,114 & 0,071 & 0,07 & 61,47 & A \\
\hline 2,64 & 0,075 & 0,075 & 46,04 & A \\
\hline 3,517 & 0,067 & 0,065 & 79,22 & A \\
\hline 1,3 & 0,068 & 0,063 & 29,77 & A \\
\hline 3,638 & 0,075 & 0,077 & 61,80 & A \\
\hline 2,866 & 0,063 & 0,067 & 66,61 & A \\
\hline 4,484 & 0,067 & 0,068 & 96,55 & A \\
\hline 3,189 & 0,063 & 0,065 & 76,40 & A \\
\hline 1,546 & 0,064 & 0,068 & 34,85 & $E$ \\
\hline 1,684 & 0,067 & 0,068 & 36,26 & MD \\
\hline 1,288 & 0,069 & 0,073 & 25,08 & $E$ \\
\hline 2,943 & 0,069 & 0,065 & 64,37 & MD \\
\hline 3,911 & 0,065 & 0,07 & 84,32 & MRD \\
\hline 4,073 & 0,069 & 0,067 & 86,43 & A \\
\hline 3,61 & 0,068 & 0,072 & 72,33 & MR \\
\hline 2,739 & 0,067 & 0,069 & 58,30 & \\
\hline
\end{tabular}

\begin{tabular}{ccccc}
\hline GU d5 & \multicolumn{5}{c}{$25 / 11 / 2005$} \\
\hline kgf & espessura (cm) & espessura 2 (cm) & MPa & Fratura \\
\hline 0,958 & 0,073 & 0,066 & 19,51 & $\mathrm{~A}$ \\
0,801 & 0,069 & 0,066 & 17,25 & $\mathrm{~A}$ \\
1,513 & 0,067 & 0,065 & 34,08 & $\mathrm{MD}$ \\
0,939 & 0,067 & 0,064 & 21,48 & $\mathrm{E}$ \\
3,544 & 0,065 & 0,065 & 82,29 & $\mathrm{~A}$ \\
1,042 & 0,068 & 0,065 & 23,13 & $\mathrm{~A}$ \\
1,899 & 0,065 & 0,064 & 44,78 & $\mathrm{MD}$ \\
2,632 & 0,066 & 0,064 & 61,13 & $\mathrm{MR}$ \\
1,22 & 0,063 & 0,065 & 29,23 & $\mathrm{MR}$ \\
2,062 & 0,063 & 0,065 & 49,40 & $\mathrm{~A}$ \\
3,112 & 0,07 & 0,064 & 68,14 & $\mathrm{~A}$ \\
3,012 & 0,063 & 0,068 & 68,97 & $\mathrm{~A}$ \\
3,47 & 0,064 & 0,067 & 79,39 & $\mathrm{MRD}$ \\
2,584 & 0,07 & 0,066 & 54,87 & $\mathrm{~A}$ \\
1,494 & 0,066 & 0,065 & 34,16 & $\mathrm{~A}$ \\
& & & & \\
\hline $\mathbf{2 , 0 1 9}$ & $\mathbf{0 , 0 6 7}$ & $\mathbf{0 , 0 6 5}$ & $\mathbf{4 5 , 8 5}$ & \\
\hline
\end{tabular}




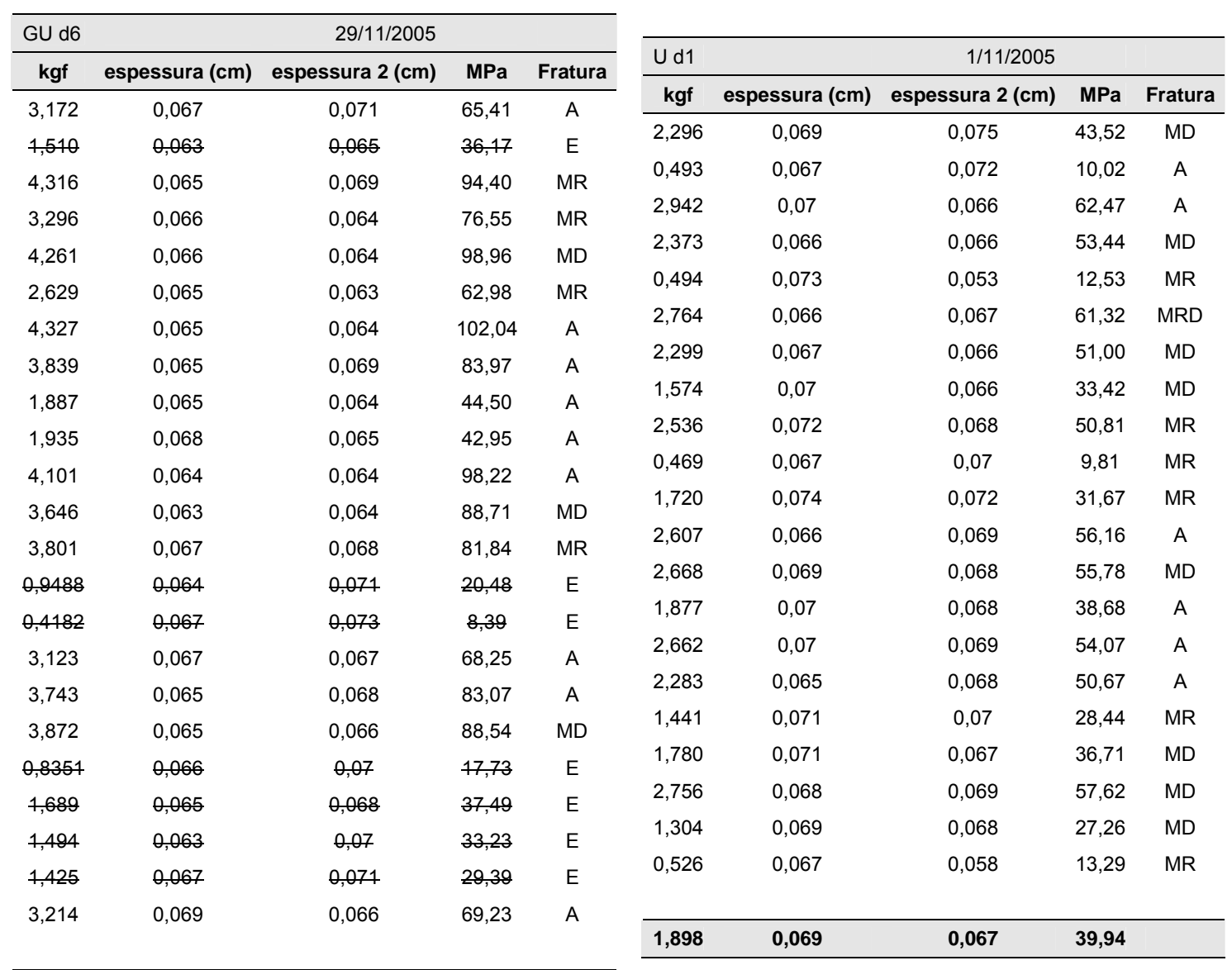

$\begin{array}{llll}2,760 & 0,066 & 0,067 & 62,28\end{array}$




\begin{tabular}{|c|c|c|c|c|c|c|c|c|c|}
\hline \multicolumn{2}{|l|}{$\mathrm{U}$ d2 } & \multicolumn{3}{|l|}{$1 / 11 / 2005$} & \multicolumn{2}{|l|}{$\cup \mathrm{d} 4$} & \multicolumn{2}{|l|}{$16 / 11 / 2005$} & \multirow[b]{2}{*}{ Fratura } \\
\hline kgf & espessura (cm) & espessura $2(\mathrm{~cm})$ & $\mathrm{MPa}$ & Fratura & kgf & espessura (cm) & espessura $2(\mathrm{~cm})$ & $\mathrm{MPa}$ & \\
\hline 1,836 & 0,066 & 0,066 & 41,35 & MR & 1,446 & 0,067 & 0,066 & 32,08 & $E$ \\
\hline 0,709 & 0,07 & 0,07 & 14,19 & MR & 2,315 & 0,064 & 0,066 & 53,76 & $A$ \\
\hline 1,951 & 0,075 & 0,071 & 35,94 & $A$ & 1,304 & 0,064 & 0,067 & 29,83 & A \\
\hline 2,023 & 0,068 & 0,07 & 41,69 & $A$ & 2,963 & 0,067 & 0,064 & 67,79 & $A$ \\
\hline 2,558 & 0,067 & 0,066 & 56,75 & A & 2,706 & 0,067 & 0,065 & 60,95 & A \\
\hline 1,880 & 0,071 & 0,069 & 37,65 & MR & 3,525 & 0,065 & 0,066 & 80,61 & $A$ \\
\hline 2,227 & 0,073 & 0,071 & 42,15 & MD & 0,718 & 0,065 & 0,068 & 15,94 & $E$ \\
\hline 1,001 & 0,067 & 0,068 & 21,55 & A & 1,237 & 0,067 & 0,065 & 27,86 & $E$ \\
\hline 1,601 & 0,072 & 0,068 & 32,08 & A & 1,856 & 0,067 & 0,065 & 41,81 & MR \\
\hline 0,547 & 0,072 & 0,068 & 10,96 & A & 2,031 & 0,067 & 0,065 & 45,75 & $E$ \\
\hline 0,754 & 0,071 & 0,072 & 14,47 & A & 3,339 & 0,065 & 0,064 & 78,74 & A \\
\hline 1,096 & 0,065 & 0,066 & 25,06 & $E$ & 1,872 & 0,069 & 0,066 & 40,33 & MD \\
\hline 1,260 & 0,071 & 0,07 & 24,87 & A & 1,452 & 0,064 & 0,068 & 32,73 & $E$ \\
\hline 1,306 & 0,069 & 0,071 & 26,15 & MR & 2,207 & 0,065 & 0,069 & 48,27 & MD \\
\hline 1,06 & 0,078 & 0,07 & 19,05 & $E$ & 1,637 & 0,069 & 0,073 & 31,88 & MR \\
\hline 1,384 & 0,075 & 0,068 & 26,62 & A & 2,756 & 0,07 & 0,067 & 57,65 & A \\
\hline 1,918 & 0,072 & 0,073 & 35,80 & A & 1,678 & 0,066 & 0,068 & 36,68 & A \\
\hline 2,133 & 0,075 & 0,068 & 41,03 & MR & & & & & \\
\hline 0,9991 & 0,07 & 0,073 & 19,18 & MD & 2,061 & 0,066 & 0,067 & 46,04 & \\
\hline 2,095 & 0,07 & 0,067 & 43,82 & A & & & & & \\
\hline \multirow[t]{3}{*}{1,517} & 0,071 & 0,069 & 30,52 & & $\mathrm{U} d 5$ & & $23 / 11 / 2005$ & & \\
\hline & & & & & kgf & espessura (cm) & espessura $2(\mathrm{~cm})$ & $\mathrm{MPa}$ & Fratura \\
\hline & & & & & 1,365 & 0,068 & 0,067 & 29,39 & MR \\
\hline U d3 & & $10 / 11 / 2005$ & & & 1,403 & 0,069 & 0,07 & 28,50 & A \\
\hline kgf & espessura (cm) & espessura $2(\mathrm{~cm})$ & $\mathrm{MPa}$ & Fratura & 1,213 & 0,066 & 0,07 & 25,76 & $A$ \\
\hline 1,249 & 0,069 & 0,069 & 25,74 & MD & 1,242 & 0,067 & 0,065 & 27,98 & $A$ \\
\hline 2,549 & 0,07 & 0,069 & 51,77 & A & 1,676 & 0,066 & 0,066 & 37,74 & MR \\
\hline 0,701 & 0,076 & 0,066 & 13,72 & $E$ & 1,411 & 0,068 & 0,064 & 31,81 & $A$ \\
\hline 1,985 & 0,08 & 0,074 & 32,89 & MD & 1,326 & 0,066 & 0,067 & 29,42 & A \\
\hline 2,533 & 0,07 & 0,067 & 52,98 & A & 0,319 & 0,067 & 0,065 & 7,19 & A \\
\hline 1,381 & 0,069 & 0,067 & 29,30 & A & 1,849 & 0,066 & 0,066 & 41,64 & $A$ \\
\hline 1,231 & 0,07 & 0,074 & 23,31 & $A$ & 2,243 & 0,067 & 0,066 & 49,76 & $A$ \\
\hline 0,9288 & 0,07 & 0,072 & 18,08 & $E$ & 1,200 & 0,065 & 0,067 & 27,03 & A \\
\hline 1,355 & 0,067 & 0,067 & 29,61 & A & 1,692 & 0,066 & 0,064 & 39,30 & A \\
\hline 1,99 & 0,069 & 0,067 & 42,23 & $A$ & 1,794 & 0,063 & 0,066 & 42,33 & MR \\
\hline 1,488 & 0,072 & 0,073 & 27,77 & A & 2,023 & 0,065 & 0,066 & 46,26 & A \\
\hline \multirow[t]{2}{*}{2,673} & 0,065 & 0,069 & 58,47 & A & 2,64 & 0,064 & 0,064 & 63,23 & A \\
\hline & & & & & 1,769 & 0,065 & 0,065 & 41,07 & A \\
\hline \multirow[t]{5}{*}{1,672} & 0,071 & 0,070 & 30,52 & & 2,05 & 0,066 & 0,063 & 48,37 & MR \\
\hline & & & & & 2,458 & 0,067 & 0,067 & 53,72 & A \\
\hline & & & & & 0,9488 & 0,066 & 0,068 & 20,74 & A \\
\hline & & & & & 0,6621 & 0,066 & 0,064 & 15,38 & MRD \\
\hline & & & & & 1,564 & 0,066 & 0,066 & 35,33 & \\
\hline
\end{tabular}




\begin{tabular}{|c|c|c|c|c|}
\hline \multirow{2}{*}{$\frac{\mathrm{U} \text { d6 }}{\mathbf{k g f}}$} & \multicolumn{4}{|c|}{ 29/11/2005 } \\
\hline & espessura (cm) & espessura $2(\mathrm{~cm})$ & $\mathrm{MPa}$ & Fratura \\
\hline 2,844 & 0,068 & 0,066 & 62,16 & A \\
\hline 1,234 & 0,064 & 0,066 & 28,66 & MR \\
\hline 2,555 & 0,072 & 0,068 & 51,19 & A \\
\hline 0,546 & 0,066 & 0,069 & 11,76 & $\mathrm{E}$ \\
\hline 1,309 & 0,065 & 0,067 & 29,49 & MR \\
\hline 3,260 & 0,065 & 0,069 & 71,31 & MR \\
\hline 2,056 & 0,064 & 0,067 & 47,04 & MR \\
\hline 1,111 & 0,066 & 0,059 & 27,99 & MR \\
\hline 2,238 & 0,065 & 0,066 & 51,18 & MR \\
\hline 1,725 & 0,068 & 0,068 & 36,60 & E \\
\hline 2,356 & 0,06 & 0,067 & 57,49 & MR \\
\hline 2,141 & 0,068 & 0,061 & 50,63 & MR \\
\hline 1,572 & 0,066 & 0,07 & 33,38 & E \\
\hline 3,015 & 0,061 & 0,068 & 71,30 & A \\
\hline 2,872 & 0,067 & 0,071 & 59,23 & MR \\
\hline 0,9398 & 0,064 & 0,081 & 17,78 & E \\
\hline 3,04 & 0,065 & 0,064 & 71,69 & A \\
\hline 2,654 & 0,069 & 0,065 & 58,05 & E \\
\hline 1,444 & 0,065 & 0,059 & 36,94 & E \\
\hline 2,982 & 0,065 & 0,066 & 68,19 & A \\
\hline 3,58 & 0,068 & 0,071 & 72,74 & A \\
\hline 3,178 & 0,063 & 0,06 & 82,48 & A \\
\hline 2,728 & 0,072 & 0,072 & 51,62 & MR \\
\hline 3,82 & 0,069 & 0,069 & 78,71 & A \\
\hline 2,097 & 0,066 & 0,068 & 45,84 & A \\
\hline 3,048 & 0,067 & 0,067 & 66,61 & A \\
\hline 2,321 & 0,066 & 0,067 & 51,54 & \\
\hline
\end{tabular}

\begin{tabular}{|c|c|c|c|c|}
\hline \multirow{2}{*}{$\frac{\text { GS d1 }}{\text { kgf }}$} & \multirow[b]{2}{*}{ espessura $(\mathrm{cm})$} & \multicolumn{2}{|l|}{$5 / 12 / 2005$} & \multirow[b]{2}{*}{ Frature } \\
\hline & & espessura $2(\mathrm{~cm})$ & $\mathrm{MPa}$ & \\
\hline 3,779 & 0,067 & 0,069 & 80,19 & A \\
\hline 2,017 & 0,066 & 0,075 & 39,97 & A \\
\hline 0,963 & 0,069 & 0,072 & 19,01 & A \\
\hline 0,725 & 0,068 & 0,07 & 14,94 & E \\
\hline 1,704 & 0,066 & 0,066 & 38,38 & A \\
\hline 1,357 & 0,065 & 0,066 & 31,03 & A \\
\hline 2,771 & 0,068 & 0,064 & 62,46 & A \\
\hline 1,07 & 0,073 & 0,064 & 22,17 & E \\
\hline 1,123 & 0,071 & 0,071 & 21,85 & A \\
\hline 2,673 & 0,075 & 0,072 & 48,56 & A \\
\hline 2,822 & 0,065 & 0,066 & 64,53 & A \\
\hline 4,627 & 0,064 & 0,067 & 105,86 & A \\
\hline 2,095 & 0,067 & 0,068 & 45,11 & A \\
\hline 3,663 & 0,069 & 0,069 & 75,48 & A \\
\hline 0,7586 & 0,065 & 0,065 & 17,61 & MR \\
\hline 2,604 & 0,068 & 0,071 & 52,91 & A \\
\hline 4,062 & 0,072 & 0,068 & 81,39 & A \\
\hline 2,861 & 0,071 & 0,067 & 59,00 & A \\
\hline 0,9557 & 0,065 & 0,068 & 21,21 & MR \\
\hline 2,682 & 0,067 & 0,066 & 59,50 & A \\
\hline 2,266 & 0,068 & 0,068 & 48,07 & \\
\hline GS d2 & & 7/12/2005 & & \\
\hline kgf & espessura $(\mathrm{cm})$ & espessura $2(\mathrm{~cm})$ & $\mathrm{MPa}$ & Fratura \\
\hline 3,462 & 0,067 & 0,065 & 77,98 & MRD \\
\hline 3,536 & 0,068 & 0,064 & 79,71 & MRD \\
\hline 2,888 & 0,064 & 0,065 & 68,10 & A \\
\hline 1,265 & 0,069 & 0,064 & 28,10 & A \\
\hline 1,147 & 0,066 & 0,07 & 24,36 & MD \\
\hline 1,789 & 0,065 & 0,066 & 40,91 & A \\
\hline 1,185 & 0,064 & 0,06 & 30,27 & MRD \\
\hline 1,474 & 0,067 & 0,065 & 33,20 & A \\
\hline 1,984 & 0,068 & 0,064 & 44,72 & A \\
\hline 2,318 & 0,063 & 0,063 & 57,29 & A \\
\hline 3,299 & 0,065 & 0,062 & 80,31 & MRD \\
\hline 3,925 & 0,069 & 0,066 & 84,55 & MRD \\
\hline 2,593 & 0,067 & 0,065 & 58,41 & MRD \\
\hline 3,263 & 0,073 & 0,077 & 56,95 & A \\
\hline 3,663 & 0,067 & 0,07 & 76,62 & A \\
\hline 3,663 & 0,070 & 0,074 & 56,10 & \\
\hline
\end{tabular}




\begin{tabular}{ccccc}
\hline GS d3 & \multicolumn{5}{c}{$13 / 12 / 2005$} \\
\hline kgf & espessura (cm) & espessura 2 (cm) & MPa & Fratura \\
\hline 1,582 & 0,063 & 0,068 & 36,23 & E \\
1,173 & 0,066 & 0,064 & 27,24 & $\mathrm{E}$ \\
2,050 & 0,067 & 0,069 & 43,50 & MD \\
0,764 & 0,065 & 0,063 & 18,30 & $\mathrm{E}$ \\
2,056 & 0,064 & 0,067 & 47,04 & $\mathrm{MR}$ \\
3,073 & 0,068 & 0,066 & 67,17 & $\mathrm{~A}$ \\
3,525 & 0,065 & 0,067 & 79,40 & $\mathrm{CR}$ \\
4,911 & 0,064 & 0,067 & 112,35 & $\mathrm{MR}$ \\
1,299 & 0,062 & 0,066 & 31,14 & $\mathrm{MR}$ \\
5,493 & 0,069 & 0,063 & 123,96 & $\mathrm{~A}$ \\
3,812 & 0,063 & 0,063 & 94,22 & $\mathrm{MR}$ \\
4,641 & 0,065 & 0,065 & 107,76 & $\mathrm{~A}$ \\
4,305 & 0,063 & 0,065 & 103,13 & $\mathrm{MD}$ \\
1,319 & 0,068 & 0,07 & 27,18 & $\mathrm{E}$ \\
2,705 & 0,065 & 0,071 & 57,50 & $\mathrm{MR}$ \\
2,602 & 0,07 & 0,068 & 53,63 & $\mathrm{~A}$ \\
2,293 & 0,065 & 0,068 & 50,89 & $\mathrm{MR}$ \\
& & & & \\
\hline $\mathbf{2 , 8 0 0}$ & $\mathbf{0 , 0 6 5}$ & $\mathbf{0 , 0 6 6}$ & $\mathbf{6 3 , 5 7}$ & \\
\hline & & & &
\end{tabular}

\begin{tabular}{ccccc}
\hline GS d5 & \multicolumn{5}{c}{$10 / 2 / 2006$} \\
\hline kgf & espessura (cm) & espessura 2 (cm) & MPa & Fratura \\
\hline 1,196 & 0,069 & 0,067 & 25,38 & MR \\
1,689 & 0,069 & 0,067 & 35,84 & A \\
1,725 & 0,069 & 0,067 & 36,60 & MR \\
3,599 & 0,065 & 0,067 & 81,07 & A \\
1,840 & 0,066 & 0,07 & 39,07 & A \\
1,816 & 0,066 & 0,067 & 40,29 & MR \\
2,527 & 0,065 & 0,069 & 55,27 & A \\
2,91 & 0,064 & 0,065 & 68,62 & MR \\
1,505 & 0,068 & 0,069 & 31,47 & E \\
2,428 & 0,064 & 0,07 & 53,17 & MD \\
3,36 & 0,07 & 0,066 & 71,35 & MR \\
2,814 & 0,065 & 0,069 & 61,55 & A \\
2,668 & 0,07 & 0,067 & 55,81 & MR \\
2,858 & 0,064 & 0,07 & 62,58 & A \\
0,926 & 0,064 & 0,067 & 21,18 & MRD \\
1,869 & 0,067 & 0,068 & 40,24 & MD \\
& & & & \\
\hline $\mathbf{2 , 2 3 3}$ & $\mathbf{0 , 0 6 7}$ & $\mathbf{0 , 0 6 8}$ & $\mathbf{4 8 , 7 2}$ & \\
\hline
\end{tabular}

\begin{tabular}{ccccc}
\hline GS d4 & \multicolumn{5}{c}{$15 / 12 / 2005$} \\
\hline kgf & espessura (cm) & espessura 2 (cm) & MPa & Fratura \\
\hline 1,249 & 0,066 & 0,065 & 28,56 & MR \\
4,702 & 0,066 & 0,065 & 107,52 & MRD \\
0,891 & 0,066 & 0,074 & 17,89 & E \\
2,282 & 0,068 & 0,067 & 49,14 & MR \\
0,714 & 0,072 & 0,064 & 15,20 & A \\
2,323 & 0,067 & 0,064 & 53,15 & MR \\
2,861 & 0,068 & 0,066 & 62,54 & MR \\
4,379 & 0,069 & 0,068 & 91,56 & MR \\
1,016 & 0,069 & 0,067 & 21,56 & A \\
1,153 & 0,068 & 0,068 & 24,46 & E \\
5,079 & 0,066 & 0,069 & 109,41 & A \\
0,793 & 0,067 & 0,071 & 16,35 & E \\
1,038 & 0,071 & 0,066 & 21,73 & MR \\
3,851 & 0,066 & 0,067 & 85,43 & MR \\
1,461 & 0,068 & 0,067 & 31,46 & A \\
3,492 & 0,065 & 0,066 & 79,85 & A \\
5,118 & 0,064 & 0,065 & 120,69 & A \\
4,14 & 0,067 & 0,065 & 93,26 & A \\
2,165 & 0,065 & 0,065 & 50,27 & MR \\
4,371 & 0,066 & 0,075 & 86,63 & MR \\
& & & & \\
\hline $\mathbf{2 , 6 5 4}$ & $\mathbf{0 , 0 6 7}$ & $\mathbf{0 , 0 6 7}$ & $\mathbf{5 8 , 3 3}$ & \\
\hline & & & &
\end{tabular}

\begin{tabular}{ccccc}
\hline GS d6 & \multicolumn{5}{c}{$17 / 2 / 2006$} \\
\hline kgf & espessura (cm) & espessura $\mathbf{2}(\mathbf{c m})$ & MPa & Fratura \\
\hline 1,756 & 0,077 & 0,067 & 33,39 & A \\
3,781 & 0,074 & 0,07 & 71,61 & MR \\
5,267 & 0,064 & 0,069 & 117,00 & MD \\
2,824 & 0,07 & 0,068 & 58,20 & A \\
3,178 & 0,067 & 0,067 & 69,45 & A \\
2,684 & 0,065 & 0,07 & 57,87 & A \\
2,031 & 0,067 & 0,066 & 45,06 & A \\
3,905 & 0,065 & 0,066 & 89,30 & A \\
1,036 & 0,068 & 0,081 & 18,45 & MR \\
0,8337 & 0,076 & 0,066 & 16,31 & MR \\
0,6339 & 0,075 & 0,069 & 12,02 & MD \\
1,403 & 0,074 & 0,069 & 26,96 & A \\
3,262 & 0,068 & 0,065 & 72,40 & A \\
2,293 & 0,067 & 0,068 & 49,37 & A \\
3,58 & 0,069 & 0,072 & 70,69 & A \\
2,434 & 0,069 & 0,074 & 46,76 & A \\
4,055 & 0,077 & 0,081 & 63,78 & A \\
0,8247 & 0,066 & 0,075 & 16,34 & E \\
2,585 & 0,066 & 0,071 & 54,12 & A \\
2,467 & 0,07 & 0,073 & 47,36 & A \\
3,666 & 0,073 & 0,072 & 68,42 & A \\
& & & & \\
\hline $\mathbf{2 , 5 9 5}$ & $\mathbf{0 , 0 7 0}$ & $\mathbf{0 , 0 7 0}$ & $\mathbf{5 2 , 6 1}$ & \\
\hline & & & &
\end{tabular}




\begin{tabular}{ccccc}
\hline $\mathrm{S}$ d1 & \multicolumn{5}{c}{$2 / 12 / 2005$} \\
\hline kgf & espessura (cm) & espessura 2 (cm) & MPa & Fratura \\
\hline 1,216 & 0,066 & 0,064 & 28,24 & MR \\
1,118 & 0,066 & 0,066 & 25,18 & A \\
1,325 & 0,064 & 0,063 & 32,24 & MR \\
3,238 & 0,072 & 0,084 & 52,52 & A \\
3,591 & 0,066 & 0,065 & 82,12 & MR \\
1,827 & 0,069 & 0,065 & 39,96 & A \\
2,822 & 0,067 & 0,067 & 61,67 & A \\
1,425 & 0,067 & 0,065 & 32,10 & A \\
1,524 & 0,065 & 0,066 & 34,85 & A \\
2,227 & 0,065 & 0,07 & 48,02 & A \\
2,662 & 0,068 & 0,068 & 56,48 & A \\
2,793 & 0,066 & 0,067 & 61,96 & MR \\
1,825 & 0,066 & 0,065 & 41,73 & A \\
1,590 & 0,066 & 0,069 & 34,25 & A \\
1,852 & 0,065 & 0,066 & 42,35 & MR \\
1,794 & 0,068 & 0,066 & 39,21 & MR \\
3,371 & 0,067 & 0,065 & 75,93 & A \\
2,566 & 0,069 & 0,068 & 53,65 & A \\
1,171 & 0,072 & 0,066 & 24,17 & MD \\
2,982 & 0,07 & 0,064 & 65,30 & A \\
& & & & \\
\hline $\mathbf{2 , 1 4 6}$ & $\mathbf{0 , 0 6 7}$ & $\mathbf{0 , 0 6 7}$ & $\mathbf{4 6 , 6 0}$ & \\
\hline
\end{tabular}

\begin{tabular}{ccccc}
\hline $\mathrm{S} \mathrm{d} 3$ & \multicolumn{5}{c}{$7 / 12 / 2005$} \\
\hline kgf & espessura (cm) & espessura 2 (cm) & MPa & Fratura \\
\hline 1,213 & 0,066 & 0,068 & 26,51 & $\mathrm{~A}$ \\
1,469 & 0,067 & 0,073 & 29,46 & $\mathrm{E}$ \\
1,330 & 0,064 & 0,062 & 32,88 & $\mathrm{E}$ \\
3,420 & 0,062 & 0,065 & 83,25 & $\mathrm{~A}$ \\
1,510 & 0,071 & 0,068 & 30,68 & $\mathrm{~A}$ \\
2,172 & 0,069 & 0,067 & 46,09 & $\mathrm{~A}$ \\
1,051 & 0,067 & 0,065 & 23,67 & $\mathrm{~A}$ \\
1,957 & 0,073 & 0,067 & 39,25 & $\mathrm{MR}$ \\
3,125 & 0,065 & 0,067 & 70,39 & $\mathrm{MRD}$ \\
2,566 & 0,065 & 0,068 & 56,95 & $\mathrm{MR}$ \\
1,093 & 0,073 & 0,067 & 21,92 & $\mathrm{~A}$ \\
1,188 & 0,067 & 0,073 & 23,83 & $\mathrm{~A}$ \\
3,211 & 0,069 & 0,072 & 63,41 & $\mathrm{MR}$ \\
2,133 & 0,067 & 0,067 & 46,61 & $\mathrm{~A}$ \\
3,781 & 0,069 & 0,069 & 77,91 & $\mathrm{~A}$ \\
1,513 & 0,067 & 0,065 & 34,08 & $\mathrm{MR}$ \\
2,836 & 0,071 & 0,071 & 55,19 & $\mathrm{MD}$ \\
1,188 & 0,074 & 0,069 & 22,82 & $\mathrm{E}$ \\
1,328 & 0,067 & 0,064 & 30,38 & $\mathrm{MRD}$ \\
1,204 & 0,066 & 0,064 & 27,96 & $\mathrm{~A}$ \\
3,346 & 0,07 & 0,07 & 66,99 & $\mathrm{~A}$ \\
& & & & \\
\hline $\mathbf{2 , 0 3 0}$ & $\mathbf{0 , 0 6 8}$ & $\mathbf{0 , 0 6 8}$ & $\mathbf{4 3 , 3 5}$ & \\
\hline & & & &
\end{tabular}

\begin{tabular}{ccccc}
\hline $\mathrm{S} \mathrm{d} 2$ & $5 / 12 / 2005$ \\
\hline $\mathbf{k g f}$ & espessura (cm) & espessura 2 (cm) & MPa & Fratura \\
\hline 1,011 & 0,066 & 0,073 & 20,59 & $\mathrm{~A}$ \\
2,635 & 0,069 & 0,069 & 54,29 & $\mathrm{~A}$ \\
2,428 & 0,065 & 0,067 & 54,69 & $\mathrm{~A}$ \\
1,153 & 0,065 & 0,067 & 25,97 & MR \\
3,406 & 0,067 & 0,068 & 73,34 & $\mathrm{~A}$ \\
2,439 & 0,069 & 0,067 & 51,76 & MD \\
1,251 & 0,065 & 0,07 & 26,97 & $\mathrm{~A}$ \\
1,231 & 0,073 & 0,066 & 25,06 & MRD \\
2,508 & 0,065 & 0,066 & 57,35 & MRD \\
0,8716 & 0,066 & 0,069 & 18,78 & A \\
2,621 & 0,067 & 0,066 & 58,15 & MR \\
1,085 & 0,071 & 0,069 & 21,73 & A \\
2,056 & 0,068 & 0,07 & 42,37 & A \\
2,607 & 0,066 & 0,067 & 57,84 & A \\
& & & & \\
\hline $\mathbf{1 , 9 5 0}$ & $\mathbf{0 , 0 6 7}$ & $\mathbf{0 , 0 6 8}$ & $\mathbf{4 2 , 0 6}$ & \\
\hline
\end{tabular}




\begin{tabular}{|c|c|c|c|c|c|c|c|c|c|}
\hline \multirow{2}{*}{$\frac{\mathrm{S} d 4}{\mathbf{k g f}}$} & \multirow[b]{2}{*}{ espessura (cm) } & \multicolumn{2}{|l|}{$13 / 12 / 2005$} & \multirow[b]{2}{*}{ Fratura } & \multirow{2}{*}{$\begin{array}{r}\mathrm{S} \text { d5 } \\
\mathbf{k g f}\end{array}$} & \multirow[b]{2}{*}{ espessura (cm) } & \multicolumn{2}{|l|}{$15 / 12 / 2005$} & \multirow[b]{2}{*}{ Fratura } \\
\hline & & espessura $2(\mathrm{~cm})$ & $\mathrm{MPa}$ & & & & espessura $2(\mathrm{~cm})$ & $\mathrm{MPa} \quad \mathrm{F}$ & \\
\hline 1,700 & 0,068 & 0,065 & 37,73 & A & 1,430 & 0,066 & 0,067 & 31,72 & A \\
\hline 1,836 & 0,065 & 0,066 & 41,98 & MR & 2,734 & 0,065 & 0,065 & 63,48 & A \\
\hline 1,066 & 0,068 & 0,069 & 22,29 & E & 3,247 & 0,066 & 0,066 & 73,12 & A \\
\hline 2,764 & 0,064 & 0,064 & 66,20 & A & 3,116 & 0,067 & 0,065 & 70,19 & MR \\
\hline 3,327 & 0,067 & 0,068 & 71,64 & MR & 1,143 & 0,07 & 0,065 & 24,64 & MR \\
\hline 1,049 & 0,07 & 0,068 & 21,62 & A & 2,194 & 0,064 & 0,067 & 50,19 & MR \\
\hline 2,376 & 0,064 & 0,067 & 54,36 & A & 3,128 & 0,074 & 0,072 & 57,59 & A \\
\hline 4,360 & 0,068 & 0,081 & 77,65 & MR & 2,770 & 0,068 & 0,067 & 59,64 & MR \\
\hline 4,051 & 0,065 & 0,064 & 95,53 & MR & 2,530 & 0,068 & 0,073 & 50,00 & MR \\
\hline 3,991 & 0,069 & 0,066 & 85,97 & MR & 2,905 & 0,066 & 0,067 & 64,45 & MR \\
\hline 2,996 & 0,065 & 0,065 & 69,56 & A & 2,469 & 0,066 & 0,066 & 55,60 & MR \\
\hline 1,563 & 0,07 & 0,066 & 33,19 & A & 1,780 & 0,068 & 0,065 & 39,51 & MR \\
\hline 2,547 & 0,068 & 0,06 & 61,24 & A & 1,579 & 0,071 & 0,064 & 34,09 & MR \\
\hline 0,642 & 0,065 & 0,063 & 15,38 & MR & 2,362 & 0,072 & 0,075 & 42,91 & MR \\
\hline 1,202 & 0,068 & 0,064 & 27,09 & A & 2,668 & 0,065 & 0,064 & 62,92 & A \\
\hline 2,853 & 0,064 & 0,065 & 67,28 & $\mathrm{MD}$ & & & & & \\
\hline 1,056 & 0,064 & 0,069 & 23,46 & A & 2,404 & 0,068 & 0,067 & 52,00 & \\
\hline 0,837 & 0,064 & 0,068 & 18,87 & E & & & & & \\
\hline 1,239 & 0,06 & 0,065 & 31,17 & MR & & & & & \\
\hline 2,549 & 0,065 & 0,06 & 64,12 & A & $\mathrm{S}$ d6 & & $10 / 2 / 200$ & & \\
\hline 2,288 & 0,064 & 0,064 & 54,80 & MR & kgf & espessura (cm) & ) espessura $2(\mathrm{~cm}$ & n) $\mathrm{MPa}$ & Fratur \\
\hline 2,784 & 0,067 & 0,065 & 62,71 & A & 2,039 & 0,067 & 0,065 & 45,93 & A \\
\hline 3,354 & 0,065 & 0,064 & 79,09 & A & 3,310 & 0,065 & 0,066 & 75,69 & A \\
\hline 1,367 & 0,064 & 0,065 & 32,24 & MR & 1,1 & 0,069 & 0,065 & 24,06 & A \\
\hline 2,323 & 0,068 & 0,066 & 50,78 & A & 3,178 & 0,064 & 0,068 & 71,64 & MR \\
\hline 2,549 & 0,067 & 0,067 & 55,70 & MRD & 3,260 & 0,076 & 0,067 & 62,81 & MR \\
\hline 1,615 & 0,066 & 0,067 & 35,83 & A & 0,721 & 0,066 & 0,066 & 16,24 & A \\
\hline 2,536 & 0,064 & 0,067 & 58,02 & A & 1,341 & 0,074 & 0,072 & 24,69 & MR \\
\hline \multirow[t]{2}{*}{2,334} & 0,069 & 0,069 & 48,09 & A & 0,478 & 0,065 & 0,063 & 11,44 & MR \\
\hline & & & & & 0,986 & 0,066 & 0,068 & 21,55 & A \\
\hline \multirow[t]{7}{*}{2,247} & 0,066 & 0,066 & 50,55 & & 3,271 & 0,071 & 0,073 & 61,91 & MR \\
\hline & & & & & 0,591 & 0,062 & 0,068 & 13,76 & A \\
\hline & & & & & 1,575 & 0,067 & 0,068 & 33,91 & A \\
\hline & & & & & 1,731 & 0,078 & 0,065 & 33,49 & $E$ \\
\hline & & & & & 2,097 & 0,066 & 0,069 & 45,17 & MR \\
\hline & & & & & 1,769 & 0,08 & 0,073 & 29,72 & A \\
\hline & & & & & 1,830 & 0,069 & 0,068 & 38,13 & \\
\hline
\end{tabular}


Anexo 2 - Cartas de aprovação do Comitê de Ética em Pesquisa

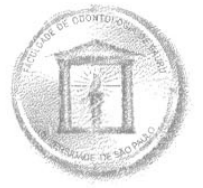

Processo $n^{\circ} 31 / 2004$

Bauru, 10 de maio de 2004 .
Universidade de São Paulo Faculdade de Odontologia de Bauru

Al. Dr. Octávio Pinheiro Brisolla, 9-75 - Bauru-SP - CEP 17012-901 - C.P. 73 PABX (0XX14)3235-8000 - FAX (0XX14)3223-4679

Comitê de Ética em Pesquisa (3235-8356)

Senhor Professor,

Informamos que após o envio da documentação pendente referente ao projeto de pesquisa "Resistência adesiva em dentina seca: efeito de um prétratamento com solução de glutaraldeído" de autoria do CD. Renato Cilli, que será desenvolvido sob sua orientação, foi novamente avaliado pelo Relator e considerado APROVADO por este Colegiado em reunião realizada no dia 28 de abril de 2004.

Comunicamos que ao término do trabalho, V.S deverá encaminhar um relatório a este Comitê para parecer final, que será utilizado para publicação.

Atenciosamente,

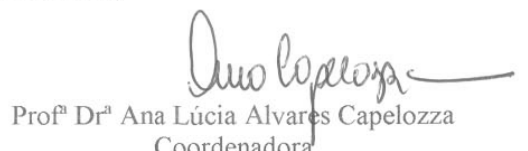

Coordenadora 


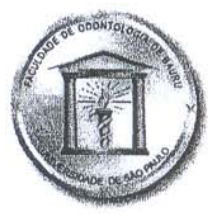

\section{Universidade de São Paulo Faculdade de Odontologia de Bauru}

Al. Dr. Octávio Pinheiro Brisolla, 9-75 - Bauru-SP - CEP 17012-901 - C.P. 73 PABX (0XX14)3235-8000 - FAX (0XX14)3223-4679

\section{Comitê de Ética em Pesquiso}

Processo $n^{\circ}$ 51/2005

Bauru, 05 de julho de 2005.

Senhor Professor,

O projeto de pesquisa encaminhado a este Comitê de Ética em Pesquisa em Seres Humanos, denominado "Análise morfológica da interface de união em dentina, formada por um sistema adesivo contendo glutaraldeido, obtida pela técnica úmida e seca", de autoria de Renato Cilli, que será desenvolvido sob sua orientação, foi enviado ao relator para avaliação.

Na reunião de 01 de julho de $\mathbf{2 0 0 5}$ o parecer do relator, aprovando - projeto, foi aceito pelo Comitê, considerando que não existem infraçőes éticas pendentes.

Informamos que após o envio do trabalho concluído, este Comitê enviará o parecer final, que será utilizado para publicação do trabalho.

Atenciosamente,

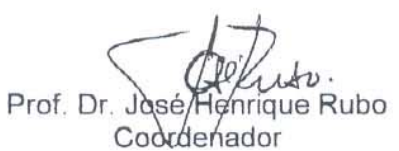

$1 \mathrm{~lm}{ }^{\circ} \mathrm{Sr}$. Prof Dr. Paulo Amarante de Araújo

DD. Docente do Departamento de Dentistica, Endodontia e Materiais Dentários 
Anexo 3 - Termo de consentimento entregue aos doadores

\section{UNIVERSIDADE DE SÃO PAULO}

Faculdade de Odontologia de Bauru

Al. Dr. Octávio Pinheiro Brisolla, 9-75 - Bauru-SP - CEP 17012-901 - C.P. 73

PABX (0XX14)235-8000 - FAX (0XX14)223-4679

\section{TERMO DE CONSENTIMENTO LIVRE E ESCLARECIDO}

\section{INFORMAÇÃO AO PACIENTE DOADOR:}

Caro paciente,

Seus dentes extraídos, nesta ocasião, serão muito úteis para pesquisas que serão realizadas na Faculdade.

Com eles, tentaremos simular o que acontece na boca quando restauramos um dente que foi destruído por cárie. Nestes dentes que você doará, serão feitas restaurações com resina composta, que são aquelas que possuem a mesma cor do dente. Depois, será avaliada a resistência dessas restaurações. Com os resultados desse trabalho, poderemos compreender melhor sobre o comportamento da resina quando usada na boca, vendo se elas descolam do dente facilmente ou não.

Agradecemos muito sua colaboração.

\section{CONSENTIMENTO DO PACIENTE:}

Pelo presente instrumento que atende às exigências legais, o Sr. (a) , portador da cédula de identidade $\mathrm{n}^{\circ}$ ciente das informações prestadas acima, firma seu

CONSENTIMENTO LIVRE E ESCLARECIDO concordando na doação de seus dentes extraídos para a realização da pesquisa proposta.

Fica claro que o paciente ou seu representante legal, pode a qualquer momento retirar seu CONSENTIMENTO LIVRE E ESCLARECIDO e deixar de participar desta pesquisa, ciente de que todas as informações prestadas tornaram-se confidenciais e guardadas por força de sigilo profissional (Art. $9^{\circ}$ do Código de Ética Odontológica).

Por estarem de acordo assinam o presente termo.

de de

Assinatura do Paciente

Telefone:
Renato Cilli - Pesquisador

Telefone: (14) 32358261 
Referências 



\section{REFERÊNCIAS}

1. Anusavice KJ. Phillips: materiais dentários. 10ª ed. Rio de Janeiro: Guanabara-Koogan; 1998. p. 15.

2. Araújo PA, Asmussen E. Aluminum oxalate/glycine solutions as pretreatment in the Gluma bonding system. Scand J Dent Res 1989;97:552-8.

3. Araújo PA, Asmussen E. Bonding to dentine with a simplified gluma system. Int Dent J 1989;39:253-7.

4. Araújo PA, Asmussen E. The Gluma system for bonding to dentine: effect of acidic pretreatment and surface wetness on bond strength. Rev Fac Odontol Bauru 1997;5:59-63.

5. Asmussen E, Bowen RL. Effect of acidic pretreatment on adhesion to dentin mediated by Gluma. J Dent Res 1987;66(8):1386-8.

6. Asmussen E, Munksgaard EC. Bonding of restorative resins to dentine promoted by aqueous mixtures of aldehydes and active monomers. Int Dent $\mathrm{J}$ 1985;35:160-5.

7. Asmussen E, Munksgaard EC. Bonding of restorative resins to dentin by means of methacryloyl-R-isocyanate. Scand J Dent Res 1983;91:153-5.

8. Asmussen E, Munksgaard EC. Formaldehyde as bonding agent between dentin and restorative resins. Scand J Dent Res 1984;92:480-3.

9. Asmussen E. Adhesion of restorative resins to dentin: chemical and physicochemical aspects. Oper Dent 1992;17(Suppl 5):68-74.

10. Beauchamp Jr. RO, St. Clair MBG, Fennell TR, Clarke DO, Morgan KT, and Kari FW. A critical review of the toxicology of glutaraldehyde. Crit Rev Toxicol 1992;22,143-74.

11. Bedran-Russo AK, Pereira PNR, Duarte WR, Drummond JL, Yamauchi M. Application of crosslinkers to dentin collagen enhances the ultimate tensile strength. J Biomed Mater Res B Appl Biomater 2007;80(1):268-72.

12. Ber $S$, Köse $T$, Hasirci $V$. Bone tissue engineering on patterned collagen films: an in vitro study. Biomater 2005;26:1977-86.

13. Bhaskar SN. Histologia e embriologia oral de Orban. 10ª ed. São Paulo: Artes Médicas; 1989.

14. Bowen RL. Dental filling material comprising vinyl silane treated fused silica and a binder consisting of the reaction product of bis phenol and glycidyl acrylate. US patent No. 3,066,112. 1962. 
15. Bowen RL, Marjenhoff WA. Development of an adhesive bonding system. Oper Dent 1992;17(Suppl 5):75-80.

16. Buehler MJ. Nature designs tough collagen: Explaining the nanostructure of collagen fibrils. PNAS 2006;103(33):12285-90.

17. Buonocore MG. A simple method for increasing the adhesion of acrylic filling materials to enamel surfaces. J Dent Res 1955;34:849-53.

18. Buonocore MG, Willeman W, Brudevold F. A report on a resin composition capable of bonding to human dentin surfaces. J Dent Res 1956;35: 846-51.

19. Carvalho RM, Mendonça JS, Santiago SL, Silveira RR, Garcia FCP, Tay FR, Pashley $\mathrm{DH}$. Effects of HEMA/solvent combinations on bond strength to dentin. J Dent Res 2003;82(8):597-601.

20. Carvalho RM, Silva e Souza Júnior MH, Yoshiyama M, Pashley DH. Effects of dehydration on the modulus of elasticity of demineralized human dentin. Rev FOB 1996;4(1/2):1-7.

21. Carvalho RM, Tay FR, Sano H, Yoshiyama M, Pashley DH. Long-term mechanical properties of EDTA-demineralized dentin matrix. J Adhes Dent 2000;2:193-9.

22. Carvalho RM, Yoshiyama M, Pashley EL, Pashley DH. In vitro study on the dimensional changes of human dentine after demineralization. Archs Oral Biol 1996;41(4):369-77.

23. Chang $\mathrm{MC}$, Ko C-C, Douglas $\mathrm{WH}$. Preparation of hydroxyapatite-gelatin nanocomposite. Biomater 2003;24:2853-62.

24. Dall'Orologio GD, Lorenzi R, Anselmi M, Opisso V. Dentin desensitizing effects of Gluma Alternate, Health-Dent desensitizer and Scotchbond Multi-Purpose. Am J Dent 1999;12-103-6.

25. Darvell BW, editor. Materials science for dentistry. $7^{\mathrm{a}}$. ed. Hong Kong; 2002. p. 234-9.

26. Davidson DF, Suzuki M. The Gluma bonding system: A clinical evaluation of its various components for the treatment of hypersensitive root dentin. J Can Dent Assoc 1997;63(1):38-41.

27. Davidson CL. Principles of adhesion. In: Dall'orologio GD, Fuzzi M, Prati C, editors. Adhesion on restorative dentistry. Proceedings of the International Symposium; 1995 Nov 18; Bologna, Italia; 1995. p.1-4.

28. Duke ES, Lindemuth JS. Variability of clinical dentin substrates. Am J Dent 1991;4(5):241-6. 
29. Erickson RL. Surface interactions of dentin adhesive materials. Oper Dent 1992;17(Suppl 5):81-94.

30. Feilzer AJ, De Gee AJ, Davidson CL. Setting stress in composite resin in relation to configuration of the restoration. J Dent Res 1987;66(11):1636-9.

31. Fusayama T. New concepts in operative dentistry. Differentiating two layers of carious dentin and using an adhesive resin. Chicago (IL): Quintessence Publishing Co., Inc.; 1980.

32. Fusayama $T$, Nakamura $M$, Kurosaki N, Iwaku M. Non-pressure adhesion of a new adhesive restorative system. J Dent Res 1979;58(4):1364-70.

33. Gage JP, Francis MJO, Triffitt JT. Collagen and dental matrices. Sevenoaks: Wright, Butterworth \& Co. (Publishers) Ltd.; 1989.

34. Göpferich A. Mechanisms of polymer degradation and erosion. Biomaterials 1996;17:103-114.

35. Gould BS. Biology of collagen. In: Gould BS, editor. Treatise on collagen. London: Academic Press; 1968. (vol 2 part A).

36. Hayat MA. Principles and techniques of electron microscopy: biological applications. 4a . ed. Cambridge: Cambridge University Press; 2000. p. 935.

37. Heymann HO, Bayne SC. Current concepts in dentin bonding: Focusing on dentinal adhesion factors. J Am Dent Ass 1993;124(5):26-36.

38. International organization for standardization. Dental materials: guidance on testing of adhesion to tooth structure. Switzerland: ISO; 1994 (Technical report ISO TR 11405)

39. Jayakrishnam A, Jameela SR. Glutaraldehyde as a fixative in bioprostheses and drug delivery matrices. Biomaterials 1996;17(5):471-84.

40. Jendersen MD, Glantz PO. Clinical adhesiveness of selected dental materials - an in vivo study. Acta Odont Scand 1981;39:39-45.

41. Kadler K, Holmes DF, Trotter JA, Chapman JA. Collagen fibril formation. Biochem J 1996;316;1-11.

42. Kanca III J. Effect of resin primer solvents and surface wetness on resin composite bond strength to dentin. Am J Dent 1992;5:213-5.

43. Kanca III J. Resin bonding to wet substrate. I. Bonding to dentin. Quintessence Int 1992;23:39-41.

44. Khor E. Methods for the treatment of collagenous tissues for bioprostheses. Biomaterials 1997;18(2):95-105. 
45. Kiernan JA. Formaldehyde, formalin, paraformaldehyde and glutaraldehyde. What they are and what they do. Microscopy Today 2000;00-1,8-12.

46. Kikuchi M, Matsumoto HN, Yamada T, Koyama Y, Takakuda K, Tanaka J. Glutaraldehyde cross-linked hydroxyapatite/collagen self-organized nanocomposites. Biomaterials 2004;25:63-9.

47. Kinloch AJ. Adhesion and adhesives: science and technology. London: Chapman and Hall; 1987.

48. Kojima K, Iguchi S, KajimaY, Yoshikuni M. Grafting of methyl metacrylate onto collagen initiated by tributylborane. J Appl Polym Sci 1983;28:87-95.

49. Kolker JL, Vargas MA, Armstrong SR, Dawson DV. Effect of desensitizing agents on dentin permeability and dentin tubule oclusion. J Adhes Dent 2002;4:211-21.

50. Kramer IRH, Mc Lean JW. Alterations of the staining reaction of dentine resulting of a constituent in a self polymerising resin. Brit Dent J 1952;6:150-3.

51. Leikin S, Parsegian VA, Yang W-H, Walrafen GE. Raman spectral evidence for hydration forces between collagen triple helices. Proc Natl Acad Sci USA 1997;94:11312-7.

52. Li H, Burrow M, Tyas MJ. Nanoleakage patterns of four dentin bonding systems. Dent Mater 2000;16(1):48-56.

53. Lickorish D, Ramshaw JAM, Werkmeister JA, Glattauer V, Howlett CR. Collagen-hydroxyapatite composite prepared by biomimetic process. J Biomed Mater Res 2004;68A:19-27.

54. Maciel KT, Carvalho RM, Ringle RD, Preston CD, Russell CM, Pashley DH. The effects of acetone, ethanol, HEMA, and air on the stiffness of human decalcified dentin matrix. J Dent Res 1996;75(11):1851-8.

55. Marshall Jr. GW. Dentin: Microstructure and characterization. Quintessence Int 1993;24:606-17.

56. Marshall Junior GW, Marshall SJ, Kinney JH, Balooch M. The dentin substrate: structure and properties relating to bonding. J Dent 1997;25(6):441-58.

57. Mjör IA, Fejerskov O. Human oral biology and histology. Copenhagen: Munksgaard; 1986.

58. Munksgaard EC, Asmussen E. Bond strength between dentin and restorative resins mediated by mixtures of HEMA and glutaraldehyde. J Dent Res 1984;63(8):1087-9. 
59. Munksgaard EC, Asmussen E. Dentin-polymer bond mediated by glutaraldehyde/HEMA. Scand J Dent Res 1985;93:463-6.

60. Munksgaard EC, Irie M, Asmussen E. Dentin-polymer bond promoted by Gluma and various resins. J Dent Res 1985;64(12):1409-11.

61. Nakabayashi N, Pashley $\mathrm{DH}$. Hybridization of dental hard tissues. Tokyo: Quintessence Publishing Co.; 1998.

62. Nakabayashi N, Kojima K, Masuhara E. The promotion of adhesion by the infiltration of monomers into tooth substrates. J Biom Mater Res 1982;16(3):265-73.

63. Nakabayashi N, Saimi $\mathrm{Y}$. Bonding to intact dentin. J Dent Res 1996;75(9):1706-15.

64. National toxicology program (NTP). NTP technical report on toxicity studies of glutaraldehyde administered by inhalation to $\mathrm{F} 344 / \mathrm{N}$ Rats and $\mathrm{B} \mathrm{C} 3 \mathrm{~F}_{1}$ Mice. Research Triangle Park (NC): U.S. Department of Health and Human Services, Public Health Service, National Institutes of Health; 1993. (NIH Publication No. 93-3348; Toxicicity Report Series number 25).

65. Nomura S, Hiltner A, Lando JB, Baer E. Interaction of water with native collagen. Biopolymers 1977;16:231-46.

66. Nör JE, Carvalho RM, Pashley DH. Effects of potencially denaturing agents on tensile properties of collagen. J Dent Res 1996;75. (Abstract \# 2635).

67. Pashley DH, Agee KA, Carvalho RM, Lee K-W, Tay FR, Callison TE. Effects of water and water-free polar solvents on the tensile properties of demineralized dentin. Dent Mater 2003;19:347-52.

68. Pashley DH, Agee KA, Nakajima M, Tay FR, Carvalho RM, Terada RSS, Harmon FJ, Lee W-K, Rueggeberg FA. Solvent-induced dimensional changes in EDTA-demineralized dentin matrix. J Biomed Mater Res 2001;56:273-81.

69. Pashley DH, Carvalho RM. Dentine permeability and dentine adhesion. J Dent 1997;25(5):355-72.

70. Pashley DH, Zhang Y, Carvalho RM, Rueggeberg FA, Russel CM. $\mathrm{H}^{+}$induced tension development in demineralized dentin matrix. $J$ Dent Res 2000;79(8):1579-83.

71. Pashley $\mathrm{DH}$. Bonding strength versus dentine structure: a modelling approach. Arch Oral Biol 1995;40(12):1109-18.

72. Pashley $\mathrm{DH}$. The effects of acid etching on the pulpodentin complex. Oper Dent 1992;17(6):229-42. 
73. Pashley DH, Sano H, Yoshiyama M, Ciucchi B, Carvalho RM. Dentin, a dynamic bonding substrate: the effects of dentin variables on resin adhesion. In: Shimono M, Maeda T, Suda H, Takahashi K, editors. Dentin-Pulp Complex. Proceedings of the International Conference on Dentin/pulp Complex; 1995 Chiba, Japão. Tokio: Quintessence Publishing; 1996. p.11-21.

74. Pashley DH, Horner JA, Brewer PD. Interactions of conditioners on the dentin surface. Oper Dent 1992;17(Suppl 5):137-50.

75. Pashley DH, Tay FR, Yiu C, Hashimoto M, Breschi L, Carvalho RM, Ito S. Collagen degradation by host-derived enzymes during aging. J Dent Res 2004;83(3):216-21.

76. Paul SJ, Welter DA, Ghazi M, Pashley DH. Nanoleakage at the dentin adhesive interface vs. $\mu$-tensile bond strength. Oper Dent 1999;24(3):181-8.

77. Perdigão J, Lopes $M$. The effect of etching time on dentin demineralization. Quintessence Int 2001;32(1):19-26.

78. Perdigão J, May Junior KN, Wilder Junior AD, Lopes M. The effect of depth of dentin demineralization on bond strengths and morphology of the hybrid layer. Oper Dent 2000;25(3):186-94.

79. Pereira PNR, Bedran-de-Castro AKB, Duarte WR, Yamauchi M. Removal of noncollagenous components affects dentin bonding. J Biom Mat Res Part B Appl Biom 2007;80B:86-91.

80. Pereira PNR, Okuda M, Sano H, Yoshikawa T, Burrow M, Tagami J. Effect of intrinsic wetness and regional difference on dentin bond strength. Dent Mater 1999;15(1):46-53.

81. Ritter AV, Swift E Jr, Yamauchi M. Effects of phosphoric acid and glutaraldehyde-HEMA on dentin collagen. Eur J Oral Sci 2001;109:348-53.

82. Robbins SL. Pathology. Philadelphia: W. B. Sauders Co.; 1967;p. 60.

83. Ruyter IE. The chemistry of adhesive agents. Oper Dent 1992;17(Suppl 5):3243.

84. Sano H, Takatsu T, Ciucchi B, Horner JA, Matthews WG, Pashley DH. Nanoleakage: leakage within the hybrid layer. Oper Dent 1995;20(1):18-25.

85. Sano H, Ciucchi B, Matthews WG, Pashley DH. Tensile properties of mineralized and demineralized human and bovine dentin. J Dent Res 1994;73(6):1205-11. 
86. Schilke R, Bau $\beta$ O, Lisson IA, Schuckar M, Geurtsen W. Bovine dentin as a substitute for human dentin in shear bond strength measurements. Am J Dent 1999;12(2):92-6.

87. Schüpbach $\mathrm{P}$, Lutz F, Finger WJ. Closing dentinal tubules by Gluma desensitizer. Eur J Oral Sci 1997;105;414-21.

88. Smith AJ. Vitality of the dentin-Pulp complex in health and disease: growth factors as key mediators. J Dent Educ 2006;67(6):678-89.

89. Söderholm K-JM. Does resin based dentine bond work? Int Dent J 1995;45(6):371-81.

90. Spencer $\mathrm{P}$, Wang $\mathrm{Y}$, Katz JL. Identification of collagen encapsulation at the dentin/adhesive interface. J Adhes Dent 2004;6(2):91-5.

91. Spencer $\mathrm{P}$, Wang $\mathrm{Y}$. Adhesive phase separation at the dentin interface under wet bonding conditions. J Biomed Mater Res 2002;62(3):447-56

92. Suzuki K, Nakai $H$. Adhesion of restorative resin to tooth substance. Treatment of acid-etched dentin by aqueous solution of HEMA. J Jap Soc Dent Mat Dev 1993;12:34-44.

93. Swift Junior E, Perdigão J, Heyman HO. Bonding to enamel and dentin: A brief history and state of the art, 1995. Quintessence Int 1995;26(2):95-110.

94. Tao L, Pashley DH. Shear bond strengths to dentin: effects of surface treatments, depth and position. Dent Mater 1988;4(6):371-8.

95. Tay FR, Gwinnett AJ, Wei SHY. Ultrastructure of the resin-dentin interface following reversible and irreversible rewetting. Am J Dent 1997;10:77-82.

96. Tay FR, Carvalho RM, Yiu CKY, King NM, Zhang Y, Agee K, Bouillaguet S, Pashley $\mathrm{DH}$. Mechanical disruption of dentin collagen fibrils during resin-dentin bond testing. J Adhes Dent 2000;2:175-92.

97. Tay FR, Gwinnett AJ, Pang KM, Wei SHY. Resin permeation into acidconditioned, moist, and dry dentin: a paradigm using water-free adhesive primers. J Dent Res 1996;75(4):1034-1044.

98. Tay FR, Pashley DH. Water treeing: a potential mechanism for degradation of dentin adhesives. Am J Dent 2003;16:6-12.

99. Tay FR, Pashley DH. Have dentin adhesives become too hydrophilic? J Can Dent Assoc 2003;69(11):726-31.

100. Tay FR, Hashimoto M, Pashley DH, Peters MC, Lai SCN, Yiu CKY, Cheong C. Aging affects two modes of nanoleakage expression in bonded dentin. J Dent Res 2003;82(7):537-41. 
101. Tay FR, Gwinnett AJ, Wei SHY. The overwet phenomenon: an optical, micromorphological study of surface moisture in the acid-conditioned, resindentin interface. Am J Dent 1996;9(1):43-8.

102. Tay FR, Pashley DH. Aggressiveness of contemporary self-etching systems. I: depth of penetration beyond dentin smear layers. Dent Mater 2001;17(4):296308.

103. Tay FR, Pashley DH, Suh BI, Carvalho RM, Itthagarun A. Single-step adhesives are permeable membranes. J Dent 2002;30:371-82,.

104. Ten Cate AR. Histologia bucal. desenvolvimento, estrutura e função. Rio de Janeiro: Ed. Guanabara; 2001.

105. Tenório DMH, Santos MF, Zom TMT. Distribution of biglycan and decorin in rat dental tissue. Braz J Med Biol Res 2003;36:1061-5

106. Uno S, Finger WJ. Effects of acidic conditioners on dentine demineralization and dimension of hybrid layers. J Dent 1996;24(3):211-6.

107. Van Meerbeek B, Vargas M, Inoue S, Yoshida Y, Peumans M, Lambrechts $P$, Vanherle G. Adhesives and cements to promote preservation dentistry. Oper Dent 2001;26(Suppl 6):119-44.

108. Van Meerbeek B. Dentine adhesion: morphology, physico-chemical and clinical aspects. Leuven: Catholic University of Leuven; 1993 (PhD Dissertation)

109. Van Meerbeek B, Braem M, Lambrechts P, Vanherle G. Morphological characterization of the interface between resin and sclerotic dentine. J Dent 1994;22(3):141-6.

110. Van Meerbeek B, Perdigão J, Lambrechts $P$, Vanherle G. The clinical performance of adhesives. J Dent 1998;26(1):1-20.

111. Van Rensburg BGJ. Oral biology. Carol Stream (IL): Quintessence Publishing Co., Inc.; 1995.

112. Veis, A. Dentin. In: Comper WD, editor. Extracellular matrix. Harwood Academic Publishers GmbH. Amsterdam, NL; 1996. 41-76. (Tissue function; vol 1)

113. Wang $Y$, Spencer P. Hybridization efficiency of the adhesive/dentin interface with wet bonding. J Dent Res 2003;82(2):141-5.

114. Yamauchi M. Collagen biochemistry: an overview. In: Phillips GO, editor. Advances in Tissue Banking. New Jersey (NJ): World Scientific; 2002. p. 455500. (vol 6) 
115. Yin Y, Ye F, Cui J, Zhang F, Li X, Yao K. Preparation and characterization of macroporous chitosan-gelatin/ $\beta$-tricalcium phosphate composite scaffolds for bone tissue engineering. J Biomed Mater Res 2003;67A:844-855. 
Abstract 



\begin{abstract}
Influence of glutaraldehyde priming on bond strengths of an experimental adhesive system applied to wet and dry dentin
\end{abstract}

This work tested the following null hypothesis: 1) There is no difference between resin-dentin bond strengths when a glutaraldehyde primer solution is applied onto demineralized dentin during adhesive bonding. 2) There is no difference between resin-dentin bond strengths when the same experimental adhesives systems are applied whether in dry or wet demineralized dentin conditions. Human, extracted upper third molars were selected. The oclusal surfaces were ground flat, and midcoronal dentin was exposed for bonding. Four groups of six teeth were formed. Two groups were designated for dry dentin technique and two for the wet one. After application and photopolymerization of the bonding system, a $4 \mathrm{~mm}$-high resin core build-up was fabricated over the adhesive layer. Specimens were then prepared for microtensile bond test for bond strengths evaluation. The obtained data were submitted to ANOVA and Tukey test $(\alpha=0.05)$. Glutaraldehyde primer application significantly improved resin-dentin bond strength. No significant difference was observed when the same experimental adhesive system was applied whether in dry or wet dentin conditions. Such results require to reject the first null hypothesis and accept the second one.

\title{
KEYWORDS
}

Glutaral. Tensile strength. Adhesion. Dentin. 